I NTER NATIONAL MONETARY FUND

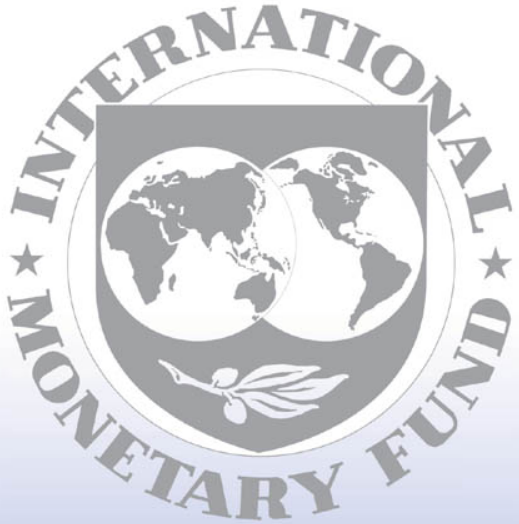

Staff

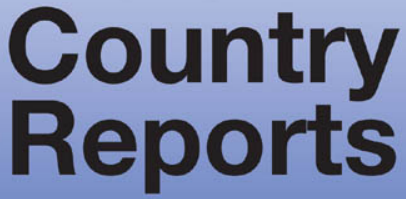




\section{Togo: 2007 Article IV Consultation and First Staff Review of the Staff-Monitored Program-Staff Report; Public Information Notice on the Executive Board Discussion; and Statement by the Executive Director for Togo}

Under Article IV of the IMFs Articles of Agreem ent, the IMF holds bilateral discussions with members, usually every year. In the context of the 2007 Article IV consultation with Togo and first staff review of the staff-monitored program, the following documents have been released and are included in this package:

- $\quad$ the staff report for the 2007 Article IV Consultation and First Staff Review of the StaffMonitored Program, prepared by a staff team of the IMF, following discussions that ended on March 13, 2007, with the officials of Togo on economic developments and policies. Based on information available at the time of these discussions, the staff report was completed on May 22, 2007. The views expressed in the staff report are those of the staff team and do not necessarily reflect the views of the Executive Board of the IMF;

- $\quad$ a Public Information Notice (PIN) summarizing the views of the Executive Board as expressed during its June, 8, 2007 discussion of the staff report that concluded the Article IV consultation; and

- $\quad$ a statement by the Executive Director for Togo.

The document listed below has been or will be separately released.

\section{Statistical Appendix}

The policy of publication of staff reports and other documents allows for the deletion of market-sensitive information.

To assist the IMF in evaluating the publication policy, reader comments are invited and may be sent by e-mail to publicationpolicy@imf.org.

Copies of this report are available to the public from

International Monetary Fund • Publication Services

$70019^{\text {th }}$ Street, N.W. • Washington, D.C. 20431

Telephone: (202) 623-7430 • Telefax: (202) 623-7201

E-mail: publications@imf.org • Internet: http://www.imf.org

Price: $\$ 18.00$ a copy

\section{International Monetary Fund Washington, D.C.}


This page intentionally left blank

CInternational Monetary Fund. Not for Redistribution 


\section{INTERNATIONAL MONETARY FUND}

\section{TOGO}

\section{Staff Report for the 2007 Article IV Consultation and First Staff Review of the Staff-Monitored Program}

Prepared by the African Department (in consultation with other departments)

Approved by Sharmini Coorey and Adnan Mazarei

May 22, 2007

Objectives: A mission visited Togo February 28-March 13, 2007, for the 2007 Article IV consultation discussions and review of the staff-monitored program (SMP).

Country representatives: The mission met with President Faure Gnassingbé, Finance Minister Boukpessi, National Director of the BCEAO Gbéasor, other senior officials, donors, trade associations, banks, enterprises, and the media. The new Finance Minister, Mr. Ayassor, met with staff at the Spring Meetings in Washington.

Mission team: The mission team comprised Mr. Mumssen (head), Mr. Gijon, Mr. Haacker, Ms. Larangeira, and Mr. Rosa (all AFR). Mr. Yao, the Fund's resident representative, and Mr. Assimaidou, Alternate Executive Director for Togo, participated in the discussions. The mission was joined by World Bank staff and overlapped with a Fund technical assistance mission focused on bank restructuring.

Article IV consultation: The discussions focused on reforms to revive economic growth, achieve a sustainable fiscal position, and strengthen the banking sector. A debt sustainability analysis (DSA) was prepared jointly with World Bank staff (Supplement I). Data weaknesses continued to hamper the effectiveness of surveillance (Supplement II).

Exchange arrangements: Togo has accepted the obligations of Article VIII, Sections 2, 3 , and 4. Togo shares a common currency (CFA franc), pegged against the euro, with other WAEMU members. The BCEAO conducts monetary and exchange rate policies for the region. Banks are supervised by the WAMU Banking Commission.

Use of Fund resources: Successful performance under the SMP (Country Report 07/22) through end-June 2007 could pave the way for a PRGF arrangement (the most recent arrangement expired in 1998) and HIPC debt relief. Togo is current on its obligations to the IMF, but has large arrears to the World Bank, the AfDB, and others. 


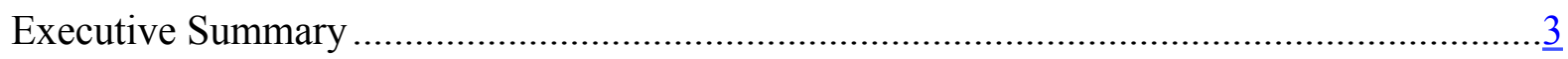

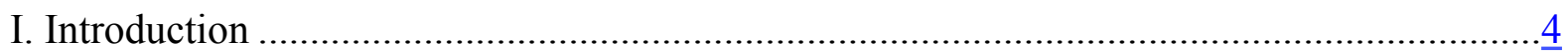

II. Recent Developments and Performance Under the SMP................................................. 4

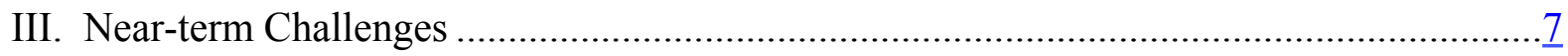

IV. Medium-Term Reform Agenda …...............................................................................

A. Overview: Key Challenges ……………………..............................................

B. Medium-term Scenarios ..............................................................................12

C. Reviving Economic Growth and External Competitiveness..................................14

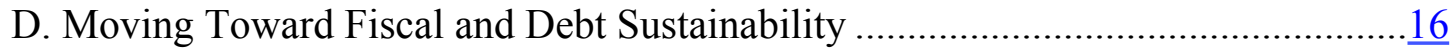

E. Strengthening the Banking Sector .......................................................................

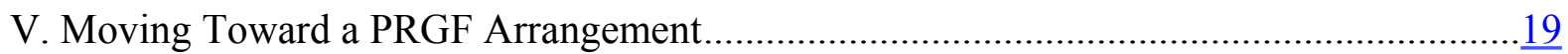

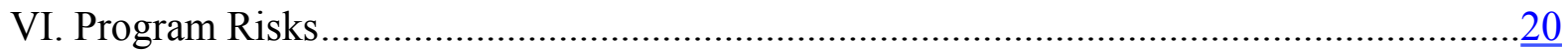

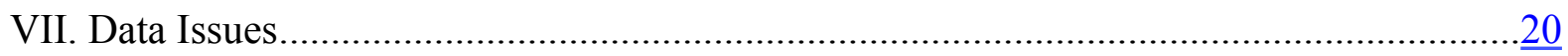

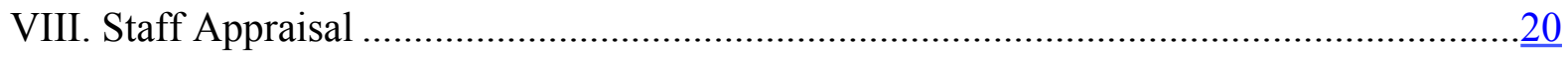

Boxes

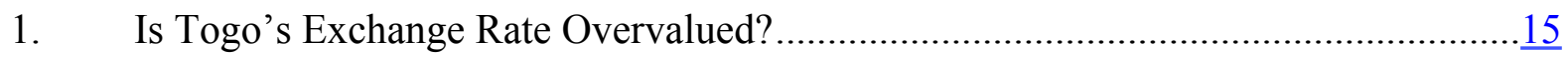

Tables

1. Quantitative Benchmarks Under the Staff-Monitored Program ................................... $\underline{5}$

2. Structural Benchmarks Under the Staff-Monitored Program …................................

3. Medium-Term Scenarios With and Without Reforms and Debt Relief, 2006-10 …...13

4. Selected Economic and Financial Indicators, 2003-07 …….................................23

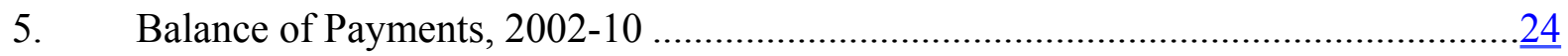

6. Financial Operation of the Central Government, 2005-10 ……................................

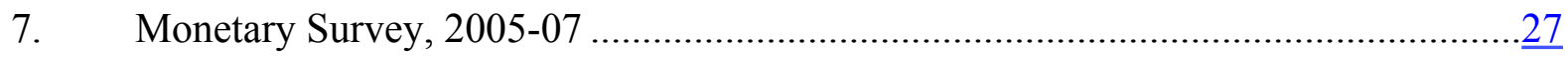

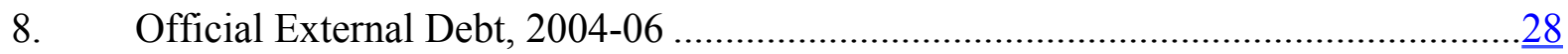

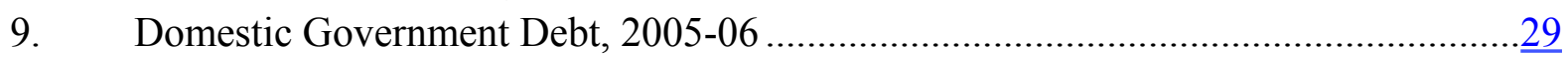

Appendix

Public Information Notice 


\section{EXECUTIVE SUMMARY}

Over the past 12 months, Togo has embarked on major political and economic reforms. The upcoming parliamentary elections are seen as a milestone in the national reconciliation process. The authorities have initiated important economic reforms, monitored under a ninemonth SMP (October 2006-June 2007).

A nascent economic recovery is underway, and performance under the SMP has been good. The improved political climate and strong services growth have offset the drag on growth caused by the collapse of the cotton sector and the deepening energy crisis. All SMP targets through February were met, reflecting recent reforms to strengthen fiscal governance.

Program risks are high in the run-up to the elections. A disruption of the election process would jeopardize economic confidence and donor support. Pre-election fiscal pressures and delays in structural reforms could derail SMP performance. To mitigate fiscal risks, the authorities pledged to strengthen expenditure controls and backload nonpriority outlays.

Togo's central medium-term challenge is to revive economic growth after a quarter century of decline. The authorities stressed that ending the political crisis and reengaging with donors will be critical to advance growth-oriented reforms, including measures to reallocate fiscal spending toward education, health, and infrastructure; resolve the energy crisis; develop the financial sector; and improve the regulatory and legal environment.

To boost competitiveness within the existing exchange rate regime, the authorities plan to pursue productivity-enhancing reforms. Despite recent real appreciation, there is little evidence that Togo's exchange rate is significantly misaligned. Reducing external imbalances will require fiscal adjustment and the removal of infrastructure and regulatory bottlenecks.

Fiscal adjustment, higher external assistance, and debt relief will be required to achieve fiscal and debt sustainability. The authorities plan to increase revenues and reallocate spending to secure a small primary surplus in the medium term. HIPC and MDRI debt relief would help bring debt to a sustainable level. The authorities stressed that a large increase in external assistance will be needed to implement the I-PRSP.

Banking sector vulnerabilities are another key challenge. The authorities plan to restructure several ailing banks in line with the recommendations of the regional Banking Commission and IMF technical assistance. The mission urged the BCEAO to take corrective action if the ongoing monetary boom started to fuel inflation or imprudent lending practices.

Successful performance under the SMP could pave the way for a PRGF arrangement later this year, but Togo's large external arrears are still a significant obstacle. 


\section{INTRODUCTION}

1. Togo faces enormous development challenges after 25 years of economic decline. The long-lasting socio-political crisis and withdrawal of donor support have taken a toll on Togo's economy, infrastructure, and institutions. Traditional export sectors have been eroded by adverse terms of trade, real exchange rate appreciation, and the mismanagement of stateowned enterprises. Governance problems and banking sector difficulties have inhibited private investment. Weak fiscal management has led to the rapid accumulation of debt and arrears. Past Article IV consultations have stressed the need to improve expenditure management, reform public enterprises, and address banking sectors problems.

\section{Over the past $\mathbf{1 2}$ months, Togo has embarked on major political and economic} reforms. A central goal is to end the socio-political crisis by holding free and transparent parliamentary elections for the first time in decades. The authorities have also stepped up their efforts to reengage with the donor community and have initiated important economic reforms, broadly consistent with past Article IV recommendations. Economic policies are monitored under a nine-month SMP, which could pave the way for a PRGF arrangement and, eventually, debt relief under the HIPC initiative and the MDRI.

\section{ReCent DeVelopments ANd PeRformance Under the SMP}

\section{The upcoming parliamentary elections are seen as a milestone in the political} reform process. A multiparty agreement in August 2006 led to the formation of a national unity government and the preparation of parliamentary elections, envisaged for the summer of 2007. Free and transparent elections are seen as critical for the resumption of large-scale donor support to Togo. Logistical and financial challenges remain, and the EU has signaled its readiness to finance a large part of the election costs.

4. A modest economic recovery is underway following the slump in 2005. Real GDP grew an estimated 2 percent in 2006, as the improved political climate and dynamism in trade-related services offset the drag on growth caused by the crisis in the cotton sector and daily electricity outages. The current account deficit rose modestly, to about 6 percent of GDP, reflecting the impact of higher oil prices and lower cotton exports. Appreciation of the euro (and thus the CFA franc) against the U.S. dollar and deteriorating terms of trade have weakened Togo's external competitiveness.

5. Despite large inflows of liquidity, inflation has been subdued. Broad money grew 22 percent in 2006, as the improved political climate led to a surge in remittances and traderelated capital inflows. While these inflows boosted the banking system's net foreign assets, they did not translate into higher domestic credit. They also did not have a discernible impact on domestic prices. Inflation fell to $2 \frac{1 / 4}{4}$ percent in the 12 months to February 2007, as food prices moderated due to improved agricultural supply conditions in neighboring countries. 

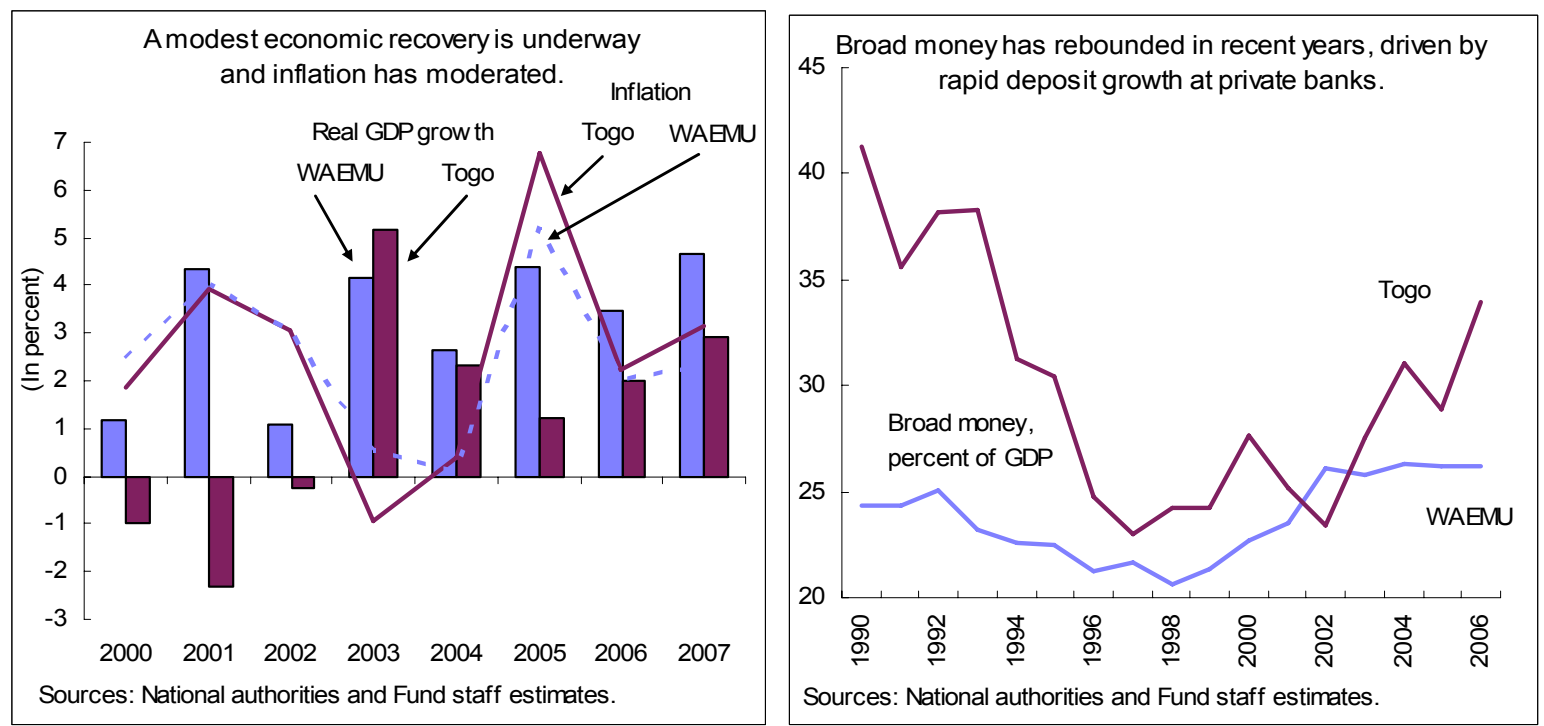

6. Fiscal policy improved markedly in the second half of 2006, and all quantitative SMP targets were comfortably met (Table 1). Revenue performance was strong, partly reflecting recent reforms in tax and customs administration, including the replacement of the tax and customs directors and closure of bank accounts used to divert revenues for offbudget operations. Revenues exceeded the end-2006 SMP target by $3 / 4$ percent of GDP due to strong tax arrears recovery and a large exceptional profit transfer from the BCEAO. The government tightened expenditure control in the second half of 2006 by curtailing offbudget operations. The proceeds from the February 2006 regional bond issue were mostly used to improve public infrastructure and reduce arrears to civil servants and cotton farmers. The domestic primary deficit for 2006 was contained at 1 percent of GDP, below the program ceiling of $13 / 4$ percent, and domestic arrears were reduced for the first time in years.

Table 1. Togo: Quantitative Benchmarks Under the Staff-Monitored Program October 1, 2006-June 30, 2007

\begin{tabular}{|c|c|c|c|c|c|}
\hline & \multicolumn{2}{|c|}{ Dec. 2006} & \multirow{2}{*}{\multicolumn{2}{|c|}{$\frac{\text { Mar. } 2007 \text { June } 2007}{\text { SMP targets }}$}} & \multirow{2}{*}{$\begin{array}{c}\text { Dec. } 2007 \\
\text { Indicative } \\
\text { targets }\end{array}$} \\
\hline & SMP target & Outturn & & & \\
\hline & \multicolumn{5}{|c|}{ (Billions of CFA francs; cumulative changes from Dec. 31, 2005) } \\
\hline Domestic primary fiscal balance (floor) & -19.3 & -12.3 & -21.8 & -26.3 & -24.5 \\
\hline Total revenue (floor) & 185.9 & 195.9 & 230.9 & 280.9 & 386.0 \\
\hline Arrears on external debt to official creditors (ceiling) & 30.0 & 27.8 & 35.4 & 45.8 & 62.3 \\
\hline Domestic payments arrears, changes in stock (ceiling) & 0.0 & -5.2 & 0.0 & 0.0 & 0.0 \\
\hline Net domestic financing (ceiling) & 27.9 & 24.8 & 31.3 & 37.6 & 23.0 \\
\hline $\begin{array}{l}\text { Central government contracting or guaranteeing of } \\
\text { nonconcessional external debt (ceiling) }\end{array}$ & 0.0 & 0.0 & 0.0 & 0.0 & 0.0 \\
\hline
\end{tabular}

Sources: Togolese authorities and Attachment I of Country Report 07/22. 
7. The $\mathbf{2 0 0 7}$ budget aims to anchor macroeconomic stability in an election year. It envisages a reduction in the primary fiscal deficit to $1 / 2$ percent of GDP, representing an underlying fiscal adjustment of about 1 percent of GDP (net of one-off revenues from the BCEAO windfall in 2006). The adjustment would come from a sharp reduction in discretionary spending, supported by reforms to minimize the use of exceptional spending procedures. Allocations for health, education, and public infrastructure would remain broadly unchanged. To bolster revenue collection, the government is implementing further reforms, including tax audits and computerization of customs.
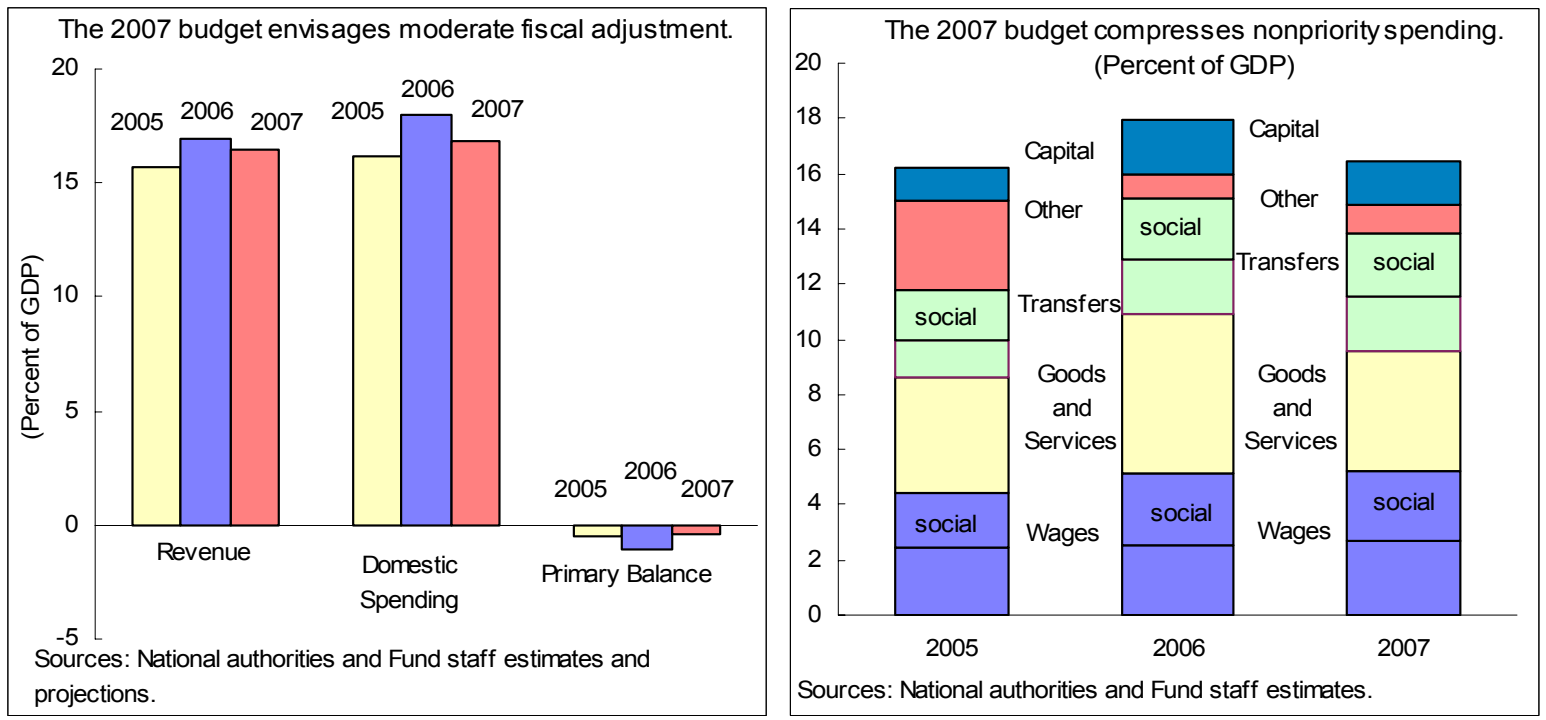

8. All structural benchmarks under the SMP through February 2007 were met, but delays are expected going forward (Table 2). Unlike in previous years, spending commitments and payment authorizations under the 2006 budget were closed before December 31, which will help control spending in 2007. In February 2007, the cabinet of ministers adopted a decree establishing internal and external audit programs at the tax department. The mission discussed with the authorities the broad principles of an arrears clearance strategy based on a draft audit that validated domestic government debt and arrears of about 21 percent of GDP at end-2005. The authorities have strengthened monitoring of bank liquidity. A preliminary report of SOTOCO's financial audit has been issued, but its completion and the preparation of a strategic audit are taking longer than envisaged. Procurement delays have held up the computerization of customs, originally envisaged for end-April 2007, but the authorities were confident that the reform would be completed soon. 
Table 2. Togo: Structural Benchmarks Under the Staff-Monitored Program

October 1, 2006-June 30, 2007

\begin{tabular}{|c|c|c|c|}
\hline Category & Structural benchmarks & Date & Status \\
\hline \multirow[t]{2}{*}{$\begin{array}{l}\text { Budget reform and } \\
\text { transparency }\end{array}$} & $\begin{array}{l}\text { Submit to IMF staff the preliminary audit report of domestic } \\
\text { government debt and arrears, and review the findings. }\end{array}$ & Feb. 2007 & Done. \\
\hline & $\begin{array}{l}\text { Close expenditure commitments for } 2006 \text { budget by end- } \\
\text { November } 2006 \text { and finish issuance of payment } \\
\text { authorizations by end-December } 2006 \text {. }\end{array}$ & Dec. 2006 & Done. \\
\hline $\begin{array}{l}\text { Expenditure } \\
\text { management }\end{array}$ & $\begin{array}{l}\text { Provide monthly data on expenditure based on exceptional } \\
\text { payment orders and limit those without prior budgetary line } \\
\text { indication for the period Jan.-June } 2007 \text { at } 6 \text { percent of total } \\
\text { expenditure. }\end{array}$ & June 2007 & In progress. \\
\hline \multirow[t]{2}{*}{$\begin{array}{l}\text { Revenue } \\
\text { administration }\end{array}$} & $\begin{array}{l}\text { Issue decree on tax administration that sets up an external } \\
\text { tax audit service and an internal audit unit. }\end{array}$ & Feb. 2007 & Done. \\
\hline & $\begin{array}{l}\text { - Make advanced computer software (SYDONIA++) } \\
\text { operational in customs administration. }\end{array}$ & April 2007 & $\begin{array}{l}\text { In progress, but with } \\
\text { delays. }\end{array}$ \\
\hline \multirow[t]{2}{*}{ Banking sector } & $\begin{array}{l}\text { Establish a mechanism for the Minister of Finance to } \\
\text { monitor liquidity of state-owned BTCI and UTB on a daily } \\
\text { basis. Alert staff about any liquidity pressures. Provide staff } \\
\text { with disaggregated liquidity data on a regular basis, as } \\
\text { indicated in the TMU. }\end{array}$ & $\begin{array}{l}\text { Continuous from } \\
\text { Dec. } 2006\end{array}$ & On track. \\
\hline & $\begin{array}{l}\text { Design a comprehensive time-bound restructuring plan for } \\
\text { BTCI and UTB in coordination with Fund banking experts, } \\
\text { the World Bank, and the regional banking commission. }\end{array}$ & June 2007 & $\begin{array}{l}\text { On track. Draft strategy } \\
\text { agreed with Fund and Bank } \\
\text { experts. }\end{array}$ \\
\hline \multirow[t]{2}{*}{$\begin{array}{l}\text { Public enterprise } \\
\text { reforms }\end{array}$} & $\begin{array}{l}\text { - Complete financial audit of SOTOCO by February } 2007 \text { and } \\
\text { the strategic audits by April } 2007 \text {. }\end{array}$ & April 2007 & $\begin{array}{l}\text { Draft financial audit report } \\
\text { completed. Strategic audit } \\
\text { delayed. }\end{array}$ \\
\hline & - Launch financial and strategic audit of phosphate sector. & June 2007 & $\begin{array}{l}\text { Authorities are seeking } \\
\text { donor support. }\end{array}$ \\
\hline
\end{tabular}

\section{NEAR-TERM CHALLENGES}

\section{The economic recovery should continue in $\mathbf{2 0 0 7}$, but risks remain high given} energy supply disruptions and the looming parliamentary elections. Real GDP growth is projected at 3 percent in 2007, driven by higher public investment, a rebound in cotton production, and continued strong growth in services related to regional trade. However, the recovery could falter if the energy crisis deepens or the elections are disrupted, which could erode economic confidence and prevent the return of donors and investors. The unexpected replacement of the finance minister in mid-March 2007 underscored the still-fluid political environment; however, President Faure Gnassingbé and the new Minister of Finance, Adji Ayassor, reaffirmed their strong commitment to economic reform and to the understandings reached for the SMP.

\section{The authorities acknowledged the need to contain fiscal pressures in the run-up}

to the elections. They were particularly concerned about the cost of organizing the elections, recently estimated at $1 \frac{1}{2}$ percent of GDP. While confident that the EU and other donors 
would provide most of the financing, the authorities acknowledged that a delay in grants would open a large, if temporary, financing gap under the SMP. ${ }^{1}$ They agreed to strengthen the monitoring of budget execution and reduce reliance on exceptional payments procedures to prevent fiscal slippages. They also plan to delay nonpriority spending until later in the year to ensure that sufficient resources are available for the electoral process, the timely payment of salaries, and the clearance of SOTOCO's arrears to cotton farmers ahead of the planting season. Backloading nonpriority spending will also mitigate the budget risks associated with potential delays in identifying external budget support to cover the full-year financing gap (1 $1 \frac{1}{4}$ percent of GDP) and potential restructuring costs for state-owned banks and enterprises.

\section{The authorities considered that current monetary policies were appropriate,} notwithstanding the recent surge in money growth. The BCEAO noted that the rapid monetary expansion in 2006 had not translated into inflation, as the additional liquidity was channeled into net foreign assets rather than domestic credit. They also saw the drop in inflation in 2006 as evidence that regionwide agricultural supplies usually have a greater impact on inflation than do monetary conditions. The authorities therefore considered that monetary tightening would be premature, but concurred with staff that it was important to monitor the factors driving money growth and its impact on prices and lending practices. They also agreed that an increase in reserve requirements, in line with WAMU policies, may become appropriate if high money growth started to fuel inflation or imprudent lending practices.

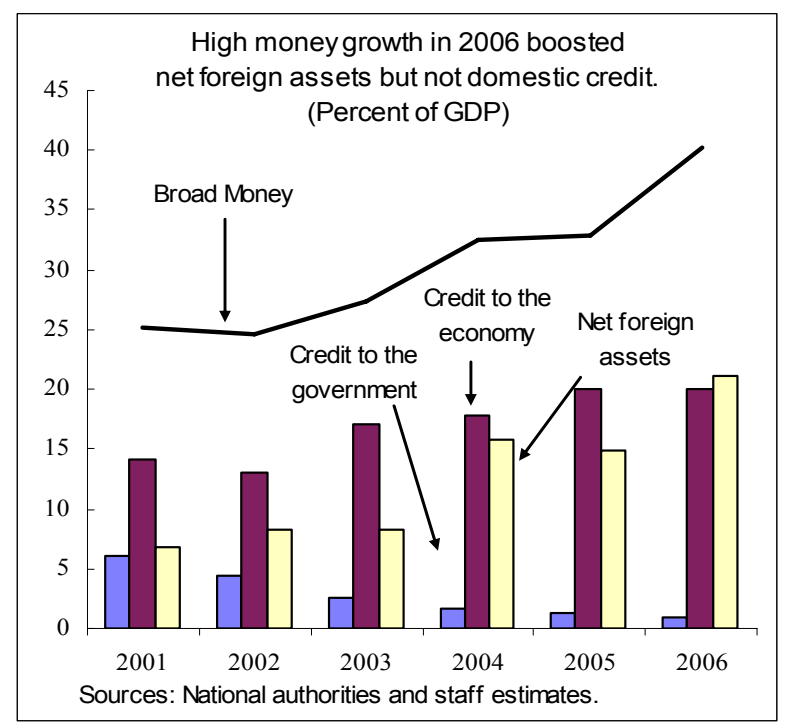

12. Understandings were reached on a bank restructuring strategy. Several banks are severely undercapitalized, primarily reflecting nonperforming loans to the troubled cotton and phosphate sectors. The mission underlined the grave macroeconomic risks associated with the undercapitalization and recurring liquidity problems at one large bank. An overlapping IMF technical assistance mission, in consultation with World Bank experts,

\footnotetext{
${ }^{1}$ To accommodate domestic bridge financing of election costs for which grants are received after June, the TMU (Country Report 07/22, Attachment II) was amended to include an adjustor that raises the net domestic financing ceiling and lowers the domestic primary fiscal balance floor by the amount of fiscal spending on the organization of the elections above the budgeted CFAF 5 billion that is not financed through grant disbursements by end-June 2007, subject to a cap on total adjustment of CFAF 12 billion.
} 
prepared a plan to strengthen and restructure three banks, consistent with existing recommendations of the WAMU Banking Commission. The authorities pledged to implement a restructuring strategy in line with these recommendations (see Section IV.E).

\section{The mission urged the authorities to accelerate reforms of state-owned} enterprises. The preliminary findings of SOTOCO's financial audit point to pervasive commercial and financial mismanagement across all layers of the company, leading to large financial losses and mounting debts, including arrears to cotton farmers. The authorities pledged to: (i) repay the remainder of these arrears by June 2007 to restore confidence; (ii) strengthen financial controls, following the replacement of SOTOCO's senior management in 2005; (iii) complete the financial and strategic audits as soon as possible; and (iv) initiate work on a broader restructuring strategy for the cotton sector, ideally with World Bank assistance. The authorities also intend to audit the phosphate sector and seek a new strategic investor once a legal settlement with the current investor is reached.

\section{There was consensus among policymakers and private observers that the} deepening energy crisis has become the most important obstacle to economic growth. Daily power outages are disrupting most sectors, including telecommunications. Regionwide power shortages have sharply reduced exports of electricity from Côte d'Ivoire and Ghana to the Benin-Togo energy company (CEB), two countries with little generation capacity and high production costs. A recent intergovernmental meeting identified large financing needs to cover the losses of CEB. While the recent interconnection with Nigeria's grid and improved hydropower conditions during the rainy season could provide temporary relief, a long-term solution would require a regionwide upgrading of capacity. The Togolese government is exploring with private investors the scope for upgrading electricity generation, including by linking to the planned Nigeria-Ghana gas pipeline.

\section{MEdiUm-Term ReForm Agenda}

\section{A. Overview: Key Challenges}

15. The Article IV discussions focused on three central medium-term challenges: (i) reviving economic growth and external competitiveness, (ii) moving toward fiscal and debt sustainability, and (iii) strengthening the banking sector.

\section{Togo's overriding economic challenge is to revive growth. Despite initially} favorable social and economic conditions, Togo's growth performance has been among the weakest in sub-Saharan Africa, with per capita income declining by an average of 1 percent a year since the early 1980s. The authorities attributed the poor growth record primarily to the long-lasting socio-political crisis and the related withdrawal of donor support, which have eroded public institutions and infrastructure. Other obstacles to growth have included adverse relative price movements, mismanagement of state-owned enterprises and banks, weak fiscal policies, mounting arrears, and governance problems. 

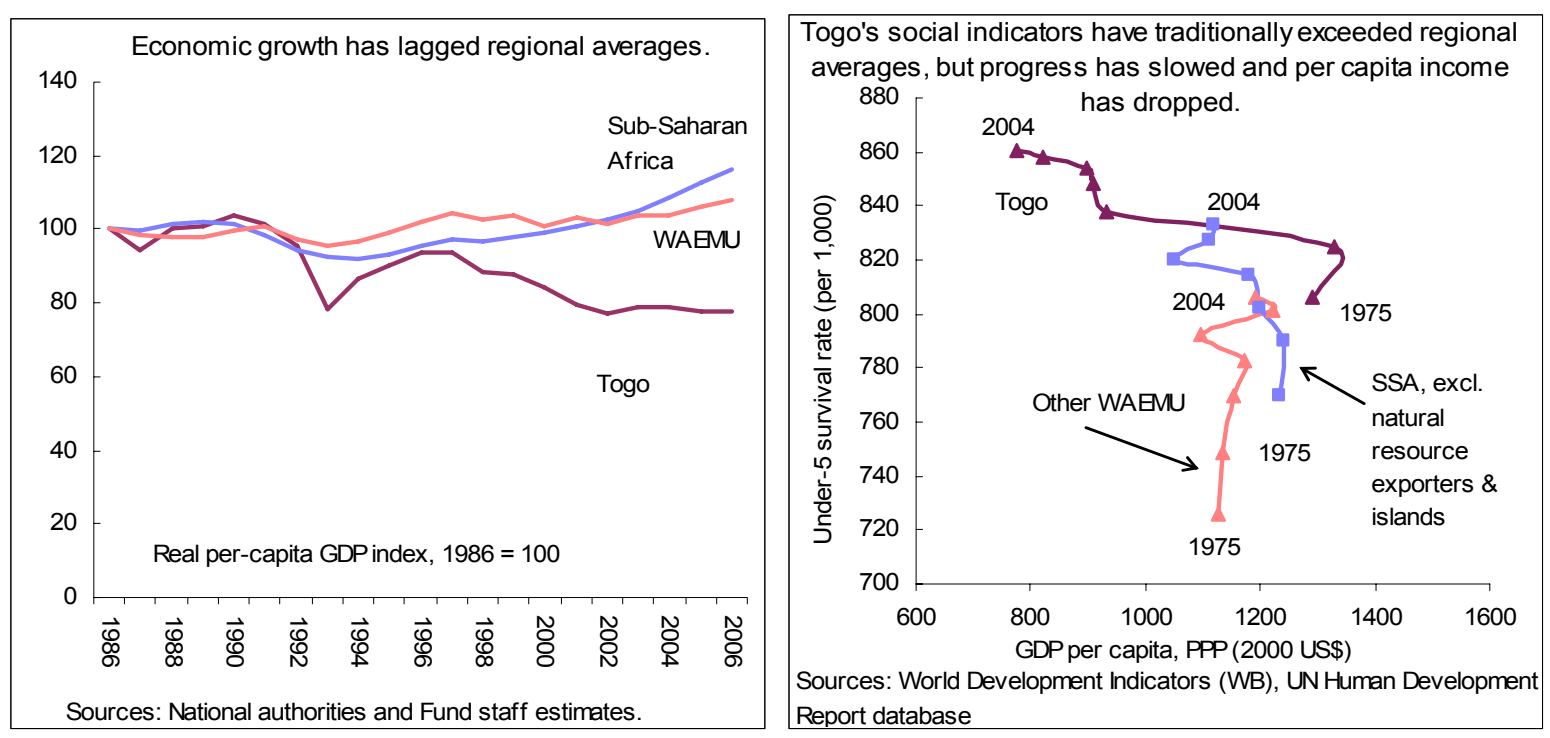

\section{Raising growth and reducing external imbalances will require steps to restore}

competitiveness. Two traditional export sectors, cotton and phosphates, have all but collapsed due to terms of trade shocks, failed sector policies, and mounting losses and arrears of public monopolies. External competitiveness has also been hampered by real exchange rate appreciation, decaying infrastructure, and a poor business environment. The goods and services deficit has risen markedly since 2003, largely owing to higher oil prices and lower cotton exports, with over half of the increase financed by short-term capital inflows.
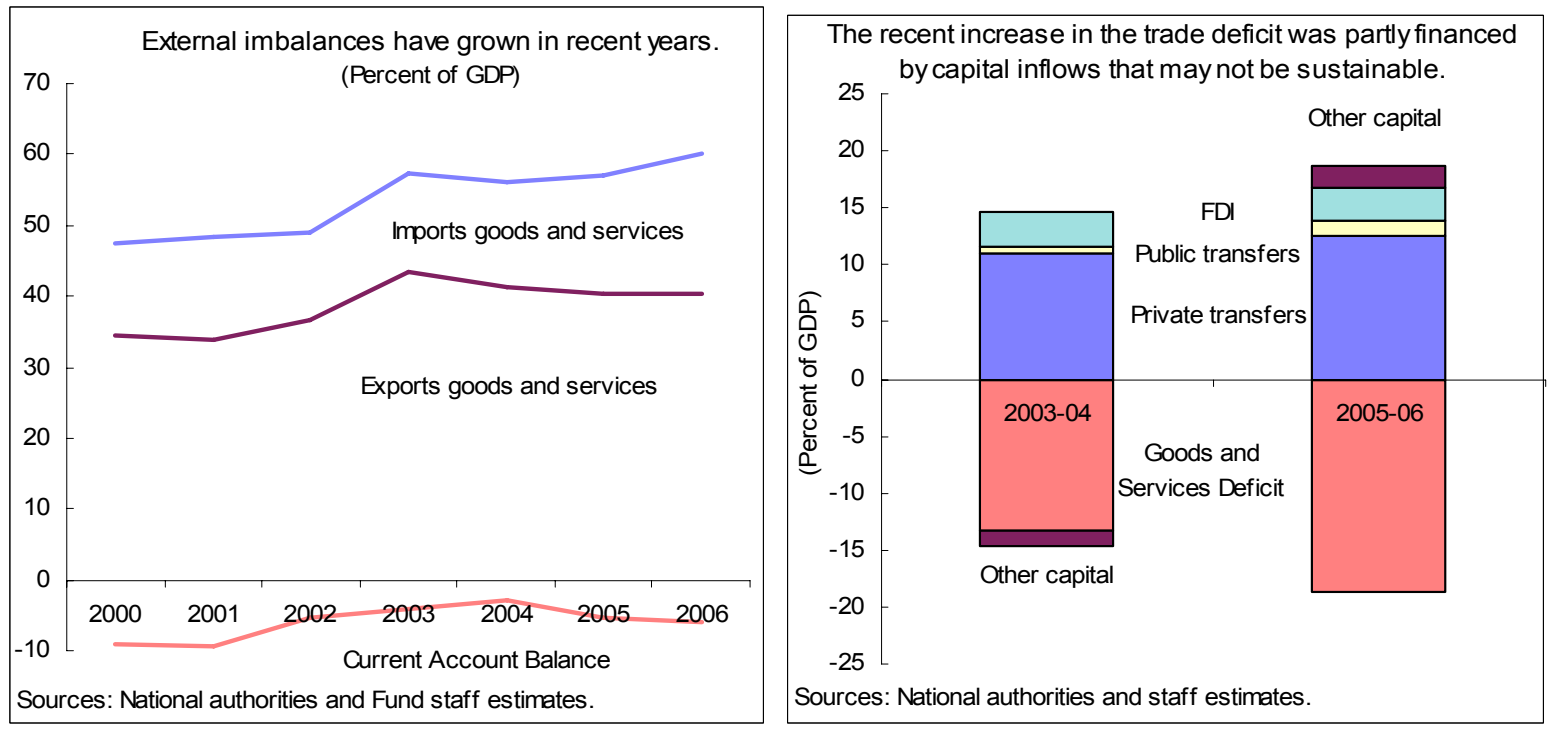

\section{Public debt is unsustainably high, and external arrears have continued to}

accumulate. Togo is in debt distress, with public debt of 103 percent of GDP at end-2006, a third of which was in arrears. As shown in the DSA prepared jointly by the staffs of the Fund and the World Bank (Supplement I), the net present value of external public debt is about twice the applicable policy-dependent debt sustainability threshold. The DSA shows that 
debt would remain unsustainable in a no-reform scenario, while it could become sustainable in an alternative scenario with economic reforms, fiscal adjustment, and comprehensive debt relief.
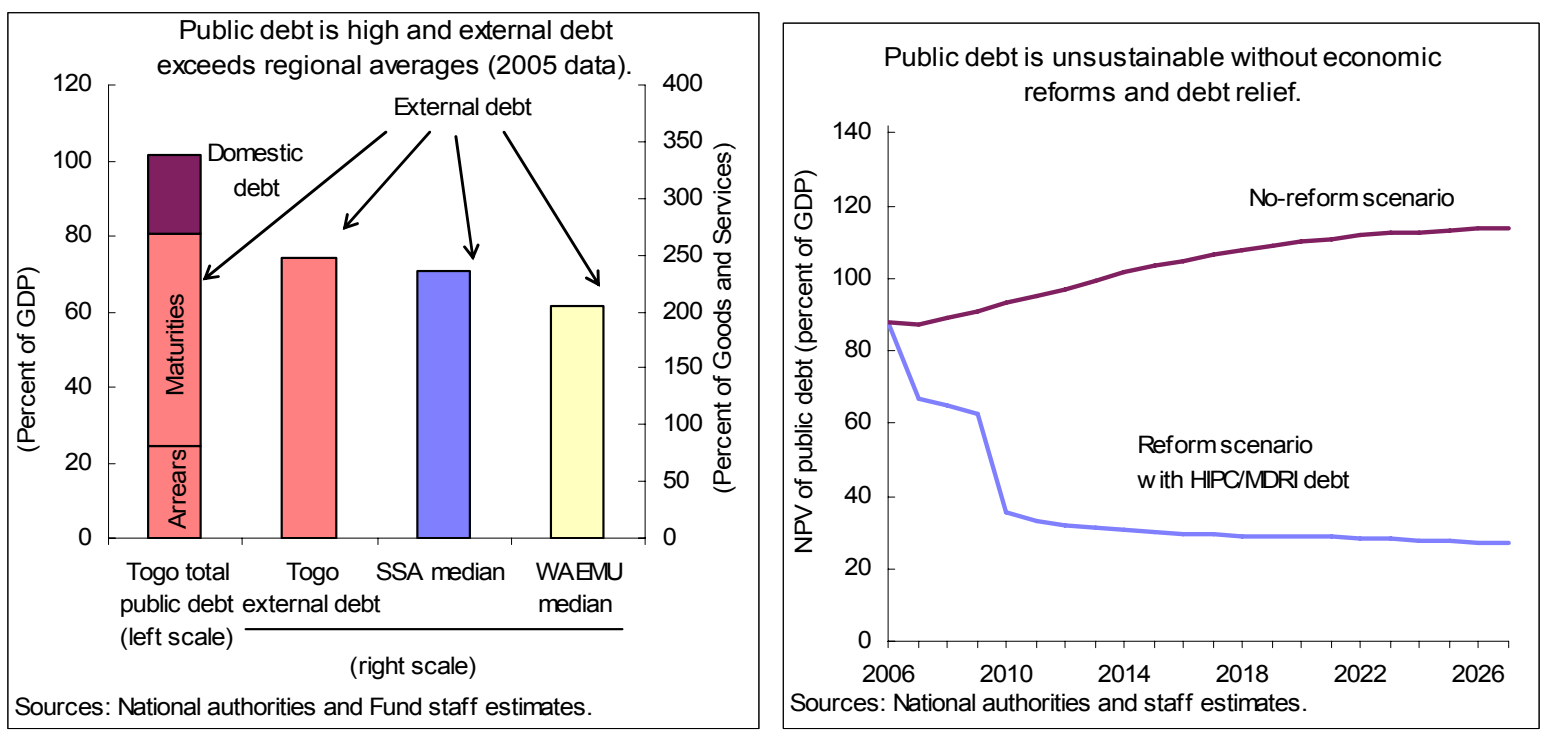

\section{Weak expenditure management and lack of external financing have squeezed}

social spending and public investment. In terms of revenues, wage bill, and fiscal balances, Togo is closer to the WAEMU convergence criteria than most other member countries. However, expenditures on health, education, and public investment are far below regional averages, largely reflecting the low external assistance, whereas other outlays are relatively high, reflecting weak expenditure management. Boosting social and investment spending within a sustainable fiscal framework would require a large increase in donor assistance combined with higher fiscal revenues and reduced nonpriority spending.
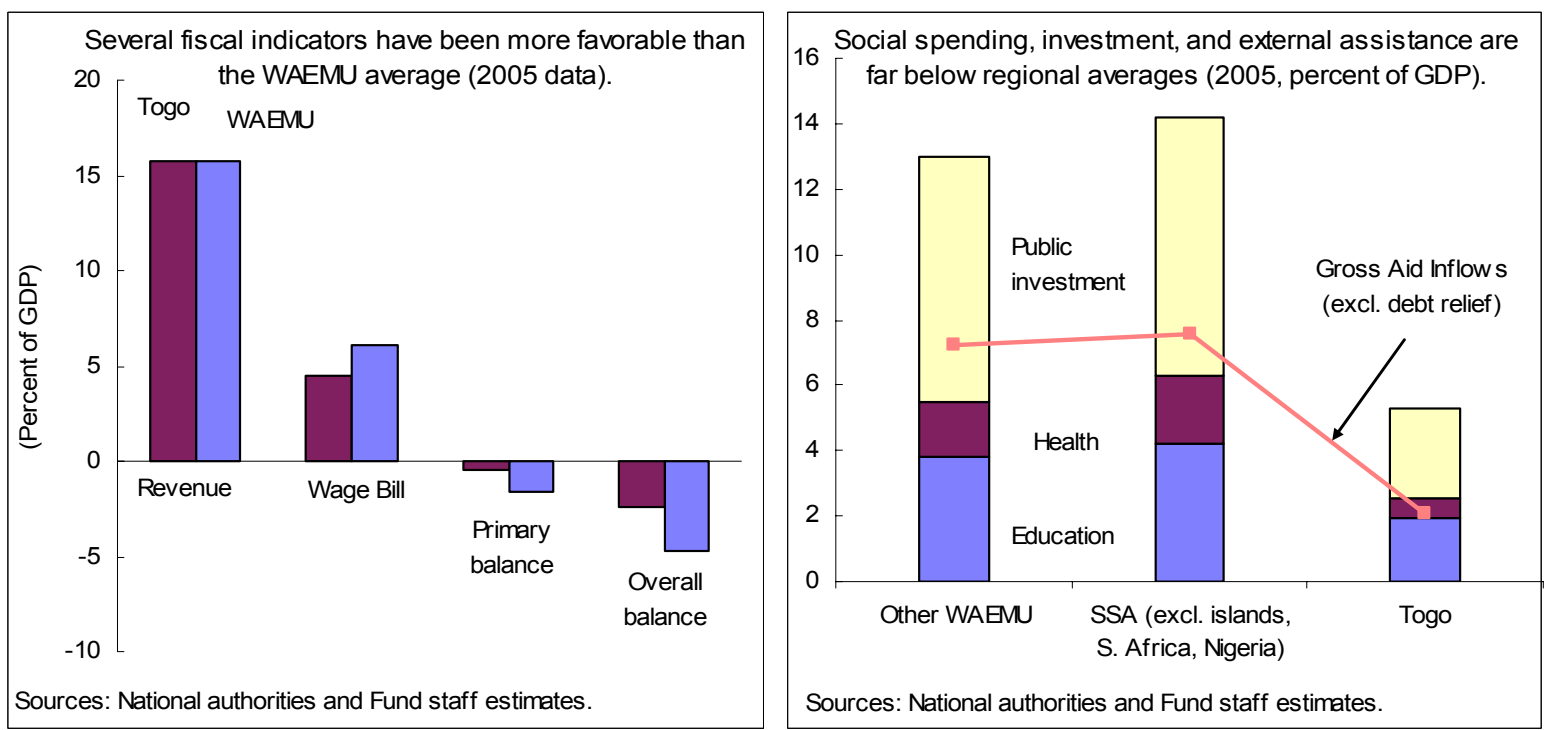


\section{B. Medium-Term Scenarios}

20. The authorities concurred with the mission that without continued reforms, economic growth would remain anemic. In the staff's no-reform scenario (Table 3 ), real GDP growth would revert to its 25 -year average of $13 / 4$ percent (below the population growth rate), external assistance would remain low, and the fiscal adjustment envisaged in the 2007 budget would not materialize. As a result, social and investment spending would remain inadequate, fiscal deficits and arrears would increase over time, public debt would remain unsustainably high, and external imbalances would persist. Moreover, without reforms, the economy's vulnerability to financial and external shocks would grow, while institutional capacity and human development indicators would continue to erode.

\section{The authorities are developing a comprehensive reform strategy to revive} economic growth and improve social conditions. The reform agenda is based on Togo's Interim PRSP (I-PRSP), which is currently being finalized with technical assistance from donors. Its key strategic pillars include: (i) political and economic governance, including political and legal reforms, and steps to strengthen public finances and budget execution; (ii) structural reforms, including steps to improve the business environment, restructure stateowned enterprises, raise agricultural productivity, build infrastructure, and develop the financial sector; and (iii) social reforms, including wider access to education, health, and safe water. The authorities agreed with the mission on the need to prioritize reform measures and estimate their costs.

\section{The authorities' central macroeconomic reform scenario is based on structural} reforms, fiscal adjustment, higher external assistance, and debt relief. The initial economic recovery is assumed to be driven by an increase in foreign-financed public investment, measures to alleviate the crisis in the cotton sector, and improved business confidence following the parliamentary elections. Over the medium term, real GDP growth of about 4 percent per year (about 1 1 $1 / 2$ percent on a per capita basis) could be sustained only with higher foreign direct investment, greater availability of credit to the private sector, and an upgrade of public infrastructure, in particular the energy sector. This will require implementation of key governance and structural reforms outlined in the I-PRSP. A threefold increase in external assistance (to the regional average), higher fiscal revenues, reduction of nonpriority spending, and HIPC/MDRI debt relief would create additional space for growthoriented spending. The fiscal adjustment would help restore policy consistency and prevent new budgetary arrears, creating a more predictable environment for suppliers, creditors, and investors. 
Table 3. Togo: Medium-Term Scenarios With and Without Reforms and Debt Relief, 2006-10 (Percent of GDP, unless otherwise indicated)

\begin{tabular}{|c|c|c|c|c|c|}
\hline & 2006 & 2007 & 2008 & 2009 & 2010 \\
\hline No reform scenario ${ }^{1}$ & & \multicolumn{4}{|c|}{ No reform scenario without debt relief 1} \\
\hline \multicolumn{6}{|l|}{ National accounts } \\
\hline Real GDP (percent change) & 2.0 & 2.1 & 1.7 & 1.7 & 1.7 \\
\hline GDP deflator (percent change) & 2.1 & 2.0 & 1.8 & 1.8 & 1.8 \\
\hline Nominal GDP (CFAF billions) & $1,158.8$ & $1,206.8$ & $1,249.4$ & $1,293.5$ & $1,339.2$ \\
\hline Investment (percent of GDP) & 13.0 & 12.5 & 12.3 & 12.3 & 12.3 \\
\hline Of which: Public & 3.6 & 3.4 & 3.3 & 3.3 & 3.3 \\
\hline Savings (percent of GDP) & 7.0 & 6.1 & 6.1 & 5.6 & 5.0 \\
\hline Of which: Public & 0.8 & 1.1 & -1.5 & -1.8 & -1.9 \\
\hline \multicolumn{6}{|l|}{ Government } \\
\hline Total revenue and grants & 18.3 & 17.5 & 17.0 & 17.0 & 17.0 \\
\hline Revenues & 16.9 & 16.0 & 16.0 & 16.0 & 16.0 \\
\hline Total expenditure & 21.1 & 21.1 & 21.8 & 22.0 & 22.1 \\
\hline Domestic primary spending & 18.0 & 17.4 & 18.0 & 18.2 & 18.2 \\
\hline Overall balance & -2.8 & -3.6 & -4.8 & -5.1 & -5.2 \\
\hline Domestic primary balance & -1.1 & -1.4 & -2.0 & -2.2 & -2.2 \\
\hline Change in domestic arrears & -0.4 & 2.0 & 2.8 & 3.1 & 3.2 \\
\hline \multicolumn{6}{|l|}{ External sector } \\
\hline Current account balance & -6.0 & -6.4 & -6.2 & -6.7 & -7.3 \\
\hline Exports of goods and services & 40.5 & 40.9 & 40.4 & 39.9 & 39.4 \\
\hline Imports of goods and services & 60.1 & 62.0 & 61.2 & 60.9 & 60.7 \\
\hline External public debt & 80.5 & 79.3 & 78.9 & 78.8 & 78.7 \\
\hline Of which: external arrears & 25.6 & 27.4 & 29.4 & 31.3 & 33.0 \\
\hline External assistance (gross; excl. debt relief) & 2.2 & 2.8 & 2.5 & 2.5 & 2.5 \\
\hline External debt service due & 2.6 & 2.6 & 3.0 & 2.9 & 2.9 \\
\hline Reform scenario $^{2}$ & & \multicolumn{4}{|c|}{ Reform scenario with debt relief ${ }^{2}$} \\
\hline National accounts & & & & & \\
\hline Real GDP (percent change) & 2.0 & 2.9 & 3.5 & 4.0 & 4.0 \\
\hline GDP deflator (percent change) & 2.1 & 2.0 & 2.0 & 2.0 & 2.0 \\
\hline Nominal GDP (CFAF billions) & $1,158.8$ & $1,216.3$ & $1,284.0$ & $1,362.1$ & $1,444.9$ \\
\hline Investment (percent of GDP) & 13.0 & 13.7 & 17.0 & 19.1 & 20.7 \\
\hline Of which: Public & 3.6 & 3.6 & 5.6 & 6.5 & 7.1 \\
\hline Savings (percent of GDP) & 7.0 & 7.3 & 10.7 & 12.9 & 15.0 \\
\hline Of which: Public & 0.8 & 1.1 & 3.0 & 4.3 & 5.3 \\
\hline \multicolumn{6}{|l|}{ Government } \\
\hline Total revenue and grants & 18.3 & 19.0 & 20.2 & 21.3 & 22.3 \\
\hline Revenues & 16.9 & 16.5 & 17.0 & 17.6 & 18.0 \\
\hline Total expenditure & 21.1 & 21.6 & 22.8 & 23.5 & 24.1 \\
\hline Domestic primary spending & 18.0 & 16.9 & 16.9 & 17.0 & 17.1 \\
\hline Overall balance & -2.8 & -2.5 & -2.6 & -2.2 & -1.8 \\
\hline Domestic primary balance & -1.1 & -0.4 & 0.1 & 0.6 & 0.9 \\
\hline Change in domestic arrears & -0.4 & 0.0 & -0.5 & -0.5 & -0.5 \\
\hline \multicolumn{6}{|l|}{ External sector } \\
\hline Current account balance & -6.0 & -6.4 & -6.3 & -6.2 & -5.7 \\
\hline Exports of goods and services & 40.5 & 40.6 & 41.7 & 42.8 & 43.9 \\
\hline Imports of goods and services & 60.1 & 61.5 & 63.2 & 64.3 & 65.2 \\
\hline External public debt & 80.5 & 72.3 & 68.2 & 65.0 & 38.8 \\
\hline Of which: external arrears & 25.6 & 0.0 & 0.0 & 0.0 & 0.0 \\
\hline External assistance (gross; excl. debt relief) & 2.2 & 3.8 & 4.6 & 5.3 & 5.9 \\
\hline External debt service due & 2.6 & 2.6 & 1.3 & 0.9 & 0.9 \\
\hline
\end{tabular}

Sources: Togolese authorities and Fund staff estimates and projections.

1 Assumes no economic reform, arrears clearance, donor reengagement, or debt relief.

2 Assumes structural reforms, fiscal adjustment, higher donor support, and external debt and arrears rescheduling/relief in 2007-10. Debt service projections are shown net of the impact of debt and arrears rescheduling/relief. 


\section{Reviving Economic Growth and External Competitiveness}

23. There was consensus that a recovery of the traditional export sectors alone could not sustain economic growth. Cotton output has fallen to a quarter of the 2001-05 average, and a rebound would restore a vital source of cash for many small farmers. However, cotton and phosphate now make up only a small share of GDP, and their revival might have only a temporary impact on economic growth. Cross-country studies point to deeper reasons for Togo's poor growth record, including weak institutions. ${ }^{2}$ This suggests the need for broader reforms to foster private sector growth across all sectors, including agriculture and the service sector, which could benefit from Togo's role as a regional trade hub.

\section{The mission stressed the need to improve external competitiveness, which has been eroded by structural bottlenecks and changes in relative prices. Competitiveness} has been undermined by a poor business environment (among the weakest in the region) and deteriorating public infrastructure. While terms-of-trade shocks and real effective exchange rate appreciation have also hampered competitiveness in recent years, there is little evidence to suggest a significant exchange rate overvaluation (Box 1). The authorities emphasized that labor costs are still very low and suggested that the long-lasting political tensions and the deepening energy crisis are largely to blame for the lack of investment and growth.
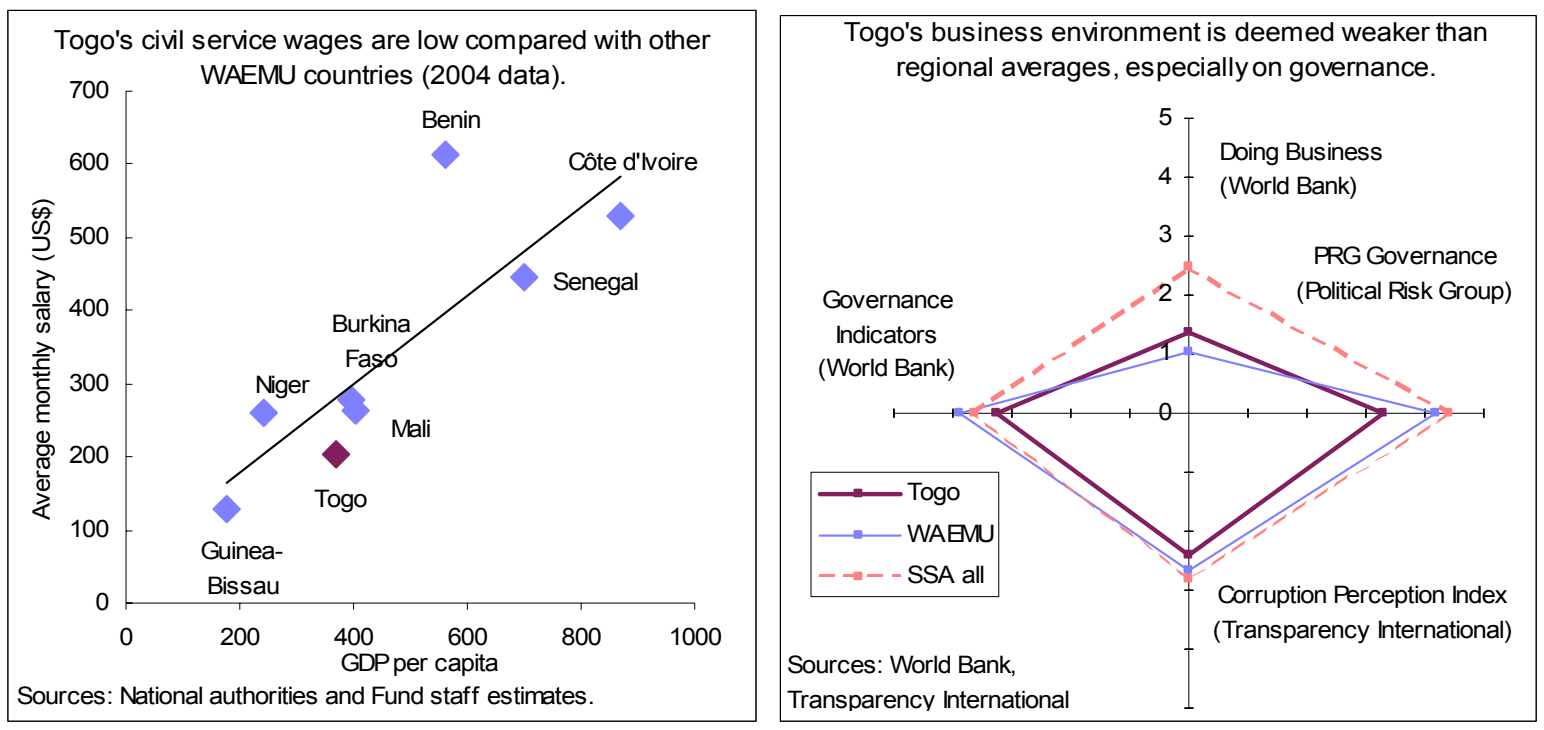

\footnotetext{
${ }^{2}$ Togo has been included in cross-country regressions on the determinants of growth (e.g. Block, Journal of Development Economics 2001, Easterly et al., American Economic Review 2004, Ndulu et al., Challenges of African Growth, The World Bank Group, 2006). The data indicate that Togo shares some growth-inhibiting characteristics with other African countries (low life expectancy, high fertility rates), and that its low per capita growth might be explained by below-average scores on institutional quality, infrastructure, and fiscal spending.
} 


\section{Box 1: Is Togo's Exchange Rate Overvalued?}

The CFA franc, which is pegged to the euro, has gradually appreciated against the U.S. dollar in recent years. Nonetheless, the real effective exchange rate (REER) for the region as a whole is still broadly in line with its estimated long-run equilibrium value, as discussed in the recent Article IV consultation for the WAEMU area. Togo's REER has tracked the regional average closely since the 1994 devaluation and is still 15 percent below the pre-devaluation level. However, Togo has also experienced persistent low growth and external imbalances since the early 1980s, its REER had appreciated relative to other WAMU members prior to 1994, and its terms of trade have deteriorated more drastically than the regional average.
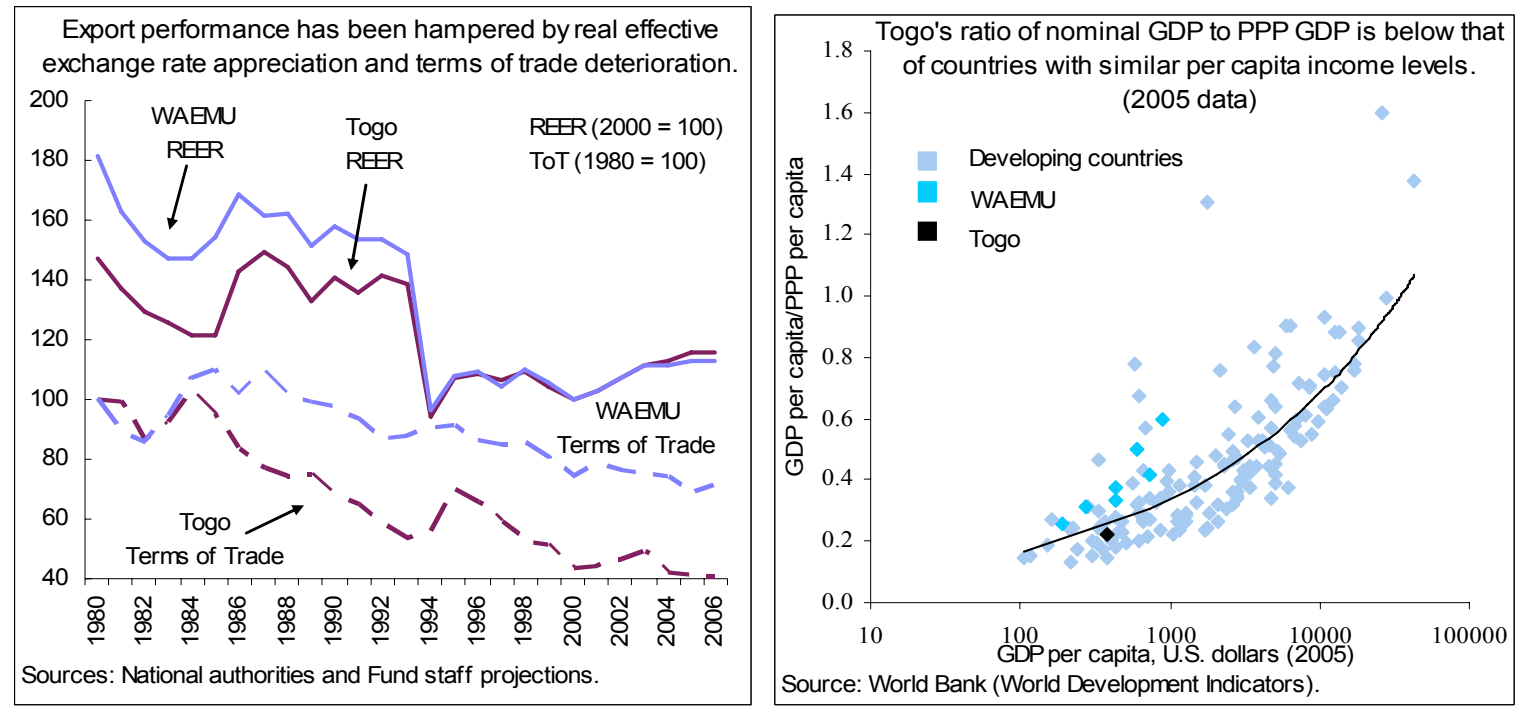

A closer examination suggests that Togo's exchange rate is not likely to be significantly overvalued. First, exports of goods and services are relatively high as a share of GDP and have grown strongly over the past decade. Second, Togo's current account deficit, 5-6 percent of GDP in 2005-06, is well below the regional average. Third, wages are among the lowest in the WAEMU region (unskilled workers earn about $\$ 50$ a month), with minimum wages and civil servant salaries frozen for more than a decade. Fourth, Togo's per capita GDP at purchasing power parity exceeds the cross-country average (including WAEMU members) in relation to nominal per capita income levels, suggesting a comparatively low price level for nontradables.

\section{The authorities intend to rely on fiscal adjustment and structural reforms to boost growth and competitiveness within the existing exchange rate regime. Membership of the WAMU currency union remains Togo's main anchor of stability, with significant benefits in terms of low inflation and access to regional markets. As Togo's wages are already comparatively low and regional labor mobility limits the scope for reducing real wages further, the authorities and staff agreed that the policy focus should be on raising productivity growth in tradables, including through steps to:}


- $\quad$ reallocate spending toward public infrastructure, education, and health (Section IV.D), while reducing nonpriority outlays;

- $\quad$ raise agricultural productivity. The authorities intend to improve rural infrastructure to reduce production bottlenecks, enhance marketability, and diversify production;

- $\quad$ improve the broader business environment, including by strengthening governance and simplifying regulations, to attract foreign direct investment. To restore confidence of local suppliers, the authorities intend to avoid new arrears and develop a repayment strategy for past arrears, following the recent debt audit;

- $\quad$ restructure ailing banks and develop the private financial sector to enhance access to credit and lower lending rates (Section IV.E);

- $\quad$ reform state-owned enterprises, starting with the clearance of arrears to cotton farmers and audits of SOTOCO. The authorities are also seeking a strong strategic investor for the phosphate sector. Broader reforms might be delayed until the World Bank can fully reengage with Togo; and

- work with regional partners and private investors to alleviate capacity constraints on energy generation and imports.

\section{Moving Toward Fiscal and Debt Sustainability}

\section{Togo faces a heavy public debt burden and looming medium-term spending} pressures. As shown in the DSA (Supplement I), debt could become sustainable through a combination of economic reforms, fiscal adjustment, and HIPC/MDRI debt relief. However, the completion point would not be reached before 2010, and debt service in cash terms could increase substantially in the period between PRGF approval and the HIPC decision point. Moreover, to raise economic growth and improve social conditions, large additional budget allocations (including a higher wage bill) will be necessary for health, education, and infrastructure. The restructuring of state-owned banks and enterprises is also expected to be costly.

\section{The authorities envisage a gradual domestic fiscal adjustment based on a} gradual increase in revenues and a reallocation of spending toward priority areas. They pointed to the strong revenue performance in 2006 and the adoption of a prudent budget for 2007 as first steps in this direction. They concurred with the mission that further adjustment is needed to achieve a sustainable fiscal position, in particular by:

- $\quad$ raising fiscal revenues to about 18 percent of GDP in 2010, based primarily on administrative reforms (see below) that could boost revenues by about $1 / 2$ percentage point of GDP per year; 
- reallocating domestically financed expenditures from nonpriority areas toward health, education, and infrastructure investment, while also supporting the restructuring of state-owned enterprises and banks; the total reallocation would amount to about 3 percentage points of GDP in 2006-10 within a stable overall domestic primary spending envelope of about 17 percent of GDP. A first step was taken in the 2007 budget, which aims to reduce nonpriority spending by about 1 percentage point of GDP; and

- $\quad$ targeting a primary fiscal surplus of about 1 percent of GDP by 2010, from a deficit of 1 percent of GDP in 2006, to avoid new arrears and provide resources for (postHIPC) external debt service and domestic arrears clearance, while minimizing new borrowing.

28. The authorities stressed that higher external assistance and comprehensive debt relief will be critical to reconcile spending needs with fiscal and debt sustainability. The decade-long disengagement from donors has weakened the state's institutional capacity, limited education and health services, and eroded Togo's public infrastructure. The domestic fiscal adjustment effort discussed above would thus not suffice to make room for the large social and infrastructure spending needs identified in the I-PRSP. There was consensus that meaningful progress toward the Millennium Development Goals (MDGs) within a sustainable fiscal framework would require, at a minimum:

- $\quad$ raising external assistance to the regional average of 6 percent of GDP by 2010, which would add another 4 percent of GDP for priority spending on social sectors, infrastructure, and capacity building. The authorities stressed that this would still fall well short of the resources needed to achieve the MDGs;

- ensuring that at least two-thirds of foreign aid is disbursed in grants rather than loans, which would support a reduction in the overall fiscal deficit from $23 / 4$ percent of GDP in 2006 to $13 / 4$ percent in 2010, a broadly sustainable fiscal position; and

- $\quad$ securing comprehensive debt relief under the HIPC initiative and the MDRI, which staff estimated would reduce annual external debt service from over $2 \frac{1}{2}$ percent of GDP in 2006 to about 1 percent of GDP from 2010 onwards, and ensure long-run debt sustainability (see DSA in Supplement I).

\section{The authorities intend to underpin the fiscal adjustment with comprehensive} reforms to strengthen fiscal governance. To support the increase in revenues, they are planning a broad set of administrative reforms, including computerization, improved audit procedures, and simplified procedures for taxpayers. The mission suggested that the authorities also review the scope for streamlining tax policies, including by limiting exemptions. The authorities noted that further tax harmonization across the WAEMU region is under consideration and that they have stepped up tax audits to control the abuse of tax 
exemptions. To improve expenditure control, the authorities intend to reinstate proper commitment and payments procedures, including by limiting exceptional payment authorizations and eliminating those without prior budget line identification. The mission urged the authorities to set up a system that allows real-time monitoring of budget execution, which would improve cash management and help policymakers make informed spending decisions. Improved expenditure tracking and procurement procedures would facilitate renewed donor financing. In the medium term, the authorities intend to rely on computerization and an improved accounting system to support budget preparation and execution. Technical assistance will be critical to support these reforms.

\section{E. Strengthening the Banking Sector}

\section{Despite repeated liquidity injections, several large banks remain fragile and pose} a risk to macroeconomic stability. Togolese banks have the highest nonperforming loan (NPL) ratio in the WAEMU area, reflecting primarily past lending to loss-making enterprises in the cotton and phosphate sectors. In 200406, the government took over NPLs of about 4 percent of GDP in exchange for government obligations. Although this reduced the sector's NPL ratio from 42 to 28 percent (still the highest in the WAEMU), three banks remain severely undercapitalized. One large bank experienced liquidity problems in 2006, which temporarily subsided after the rediscount of half of the government obligations to a foreign bank. However, the discount operation further reduced the bank's profitability, and its liquidity is still below the BCEAO's minimum reserve requirement.

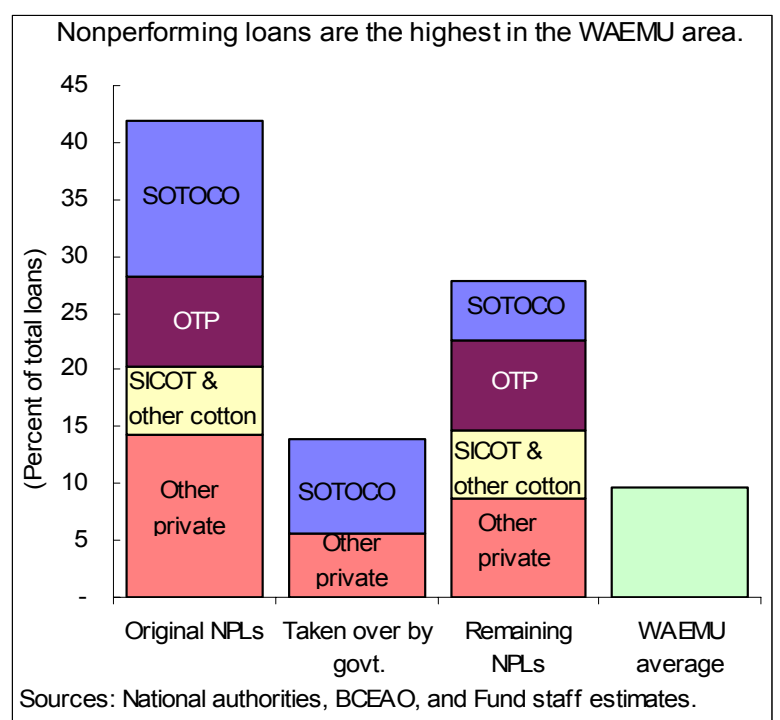

\section{The regional banking supervisor stressed that efforts to address Togo's banking} problems are ongoing. The WAMU Banking Commission has made wide-ranging recommendations to strengthen the financial position of Togo's ailing banks, including steps to improve: (i) internal accounting and information systems; (ii) corporate and management structure; (iii) credit allocation and risk evaluation mechanisms; (iv) NPL recovery; and (v) provisioning. The authorities noted that one state-owned bank had made good progress in implementing many of these measures and strengthening its financial position over the past few years. They acknowledged, however, that another large bank had severe financial problems, with recurring breaches of prudential regulations and corporate governance weaknesses. The Banking Commission's formal request that the government strengthen the bank's governance and financial position has not yet been implemented. 


\section{Understandings were reached on a plan to strengthen and restructure several} banks. An overlapping Fund technical assistance mission helped the authorities prepare a restructuring plan for three undercapitalized banks, which account for about 60 percent of private sector deposits. It found that two were relatively easy to restructure, whereas another would require significant governance changes and a large capital injection by the state, with annual budget costs estimated at about $1 / 2-3 / 4$ percent of GDP over five to eight years. The restructuring plan is based on recommendations of the Banking Commission and is broadly supported by the ministry of finance, the BCEAO, and World Bank experts. Given the fragile situation of the banks, the mission stressed the urgency to start preparing and implementing the recommended actions.

\section{There was agreement that broader financial sector reforms should complement} bank restructuring. Banking sector deposits in the sector have grown rapidly in recent years, reflecting high inflows of remittances and trade-related capital. However, most of the additional liquidity has been channeled into net foreign assets, while access to credit for the private sector has remained scarce and lending rates high. To enhance financial intermediation and lower interest rates the authorities agreed with the mission on the need to:

- $\quad$ restructure and privatize state-owned banks;

- $\quad$ improve the legal environment, in particular property registration, arbitration procedures, contract enforcement, and the ability of banks to recover collateral;

- develop microfinance to enhance access to financial services for SMEs and households; and

- $\quad$ increase the liquidity and depth of the primary and secondary securities markets.

\section{Moving Toward A PRGF ARRANGEMEnT}

34. The authorities intend to request a PRGF arrangement to anchor their economic reform program and pave the way for HIPC debt relief. A PRGF-supported program could start in the second half of 2007 subject to: (i) fully satisfactory performance under the SMP; (ii) understandings on arrears clearance with all official creditors and financing assurances from donors; and (iii) an agreed medium-term reform strategy, based on the IPRSP.

35. Togo's large arrears to multilateral creditors, particularly the World Bank, are a significant obstacle to a possible PRGF arrangement. Substantial coordination will be needed to prepare for renewed financial support from major donors and creditors in the second half of 2007. The EU is preparing several large grants that could be used in part to clear Togo's arrears to the European Investment Bank (about \$20 million). It is not yet known how the AfDB plans to address Togo's arrears (about \$15 million). World Bank staff 
is preparing a development policy needs review and is examining options for arrears clearance. Togo's \$105 million in arrears at end-2006 (Table 8) far exceed its IDA allocation, and arrears clearance would thus require exceptional treatment and/or possible help from donors. The authorities intend to intensify their dialogue with multilateral creditors and approach the Paris Club to request a rescheduling of bilateral debt and arrears.

\section{Program Risks}

\section{The main near-term risks are related to the upcoming elections and the} weakness of the banking sector. SMP performance could be derailed by fiscal pressures in the run-up to the parliamentary elections, including possible shortfalls in donor financing, spending overruns, and a slowdown in economic activity and fiscal revenues. Implementation of SMP structural benchmarks may also suffer in the pre-election period. Another risk, with potentially longer lasting economic consequences, is that a possible disruption or dispute in the election process could derail the national reconciliation process, undermine economic confidence, and prevent reengagement with donors. The precarious financial position of several banks is another substantial macroeconomic risk factor, with possible adverse spillovers to the regional level. Over the medium term, a key risk is that lack of political consensus and weak institutional could stand in the way of the envisaged economic reform program.

\section{DATA IsSues}

\section{Data weaknesses hamper surveillance and program monitoring (Informational}

Annex in Supplement II). The mission discussed with the authorities a revision of the balance of payments series to correct for underestimation of service receipts and remittances, which helped to reduce the overestimation of unrecorded net capital inflows. The mission noted the importance of upgrading national accounts data sources and reducing the twomonth lag for monetary and fiscal data. The authorities stressed the need for technical assistance to upgrade Togo's statistical capacity.

\section{STAFF APPRAISAL}

38. The recent political and economic reforms are a welcome break from the past. The formation of a national unity government and the preparations for parliamentary elections have helped restore economic confidence and supported a nascent economic recovery. Performance under the SMP has been good so far, reflecting renewed fiscal discipline and progress in strengthening governance.

\section{A key near-term challenge is to contain fiscal pressures in the run-up to the} elections. To mitigate the risks of expenditure overruns or shortfalls in donor support, it will be critical to strengthen spending controls, improve the monitoring of budget execution, and 
backload nonpriority expenditures. A smooth election process will be important for economic confidence and renewed donor support.

40. Reducing external imbalances within the existing exchange rate regime will require fiscal adjustment and productivity-enhancing reforms. Notwithstanding recent real exchange rate appreciation, there is little evidence for a significant exchange rate misalignment. To prevent a widening current account deficit and make progress toward external sustainability, it will be important to increase productivity growth, especially in tradables. This will require wide-ranging structural reforms and improved fiscal governance to ensure macroeconomic stability and policy predictability.

41. Togo's overriding medium-term challenge is to revive economic growth, following a quarter century of decline. The long-lasting political crisis and withdrawal of donor support have eroded Togo's infrastructure and institutions. To revive economic growth, it will be critical to: (i) improve governance and advance the political reform process; (ii) reengage with the donor community; (iii) reallocate budgetary resources toward health, education, and infrastructure; (iv) reform public enterprises in the cotton and phosphate sectors; (v) raise productivity in agriculture; (vi) work with regional partners to address energy shortages; (vii) develop the financial sector, including by restructuring ailing banks; and (viii) improve the business environment, including through legal and regulatory reforms.

\section{A combination of domestic fiscal adjustment, higher external assistance, and} debt relief will be required to achieve Togo's economic and social objectives within a sustainable fiscal framework. Continued reforms to strengthen fiscal governance will be critical to increase revenue collection and reallocate spending toward health, education, and infrastructure. A gradual primary fiscal adjustment combined with HIPC debt relief could help bring debt to sustainable levels and prevent the accumulation of new arrears. Meaningful progress toward the MDGs will require a substantial increase in external assistance.

43. There is an urgent need to strengthen and restructure ailing banks. The undercapitalization and liquidity problems of several large banks pose a significant risk to macroeconomic stability. The authorities' recent commitment to implement the recommendations of the WAMU Banking Commission and IMF technical assistance mission is thus welcome and should be followed up as soon as possible. It is also important to monitor closely the factors driving the current surge in money growth and consider raising reserve requirements if it starts to fuel inflation or imprudent lending practices.

\section{Successful SMP performance could become the basis for a PRGF arrangement,} but significant obstacles remain. The main near-term program risks are possible fiscal slippages in the pre-election period, delays in structural reforms, and banking sector problems. If end-June SMP targets are met, a PRGF arrangement could start later this year, 
based on an agreed medium-term economic program consistent with the finalized I-PRSP and external financing assurances. However, Togo would first have to reach understandings with official creditors, including the World Bank, on a mechanism and resources to clear arrears.

45. Data weaknesses continue to hamper surveillance. The authorities should formulate an action plan and identify technical assistance needs to improve national accounts and balance of payments statistics and reduce reporting lags for monetary and fiscal data.

46. It is proposed that the next Article IV consultation be held on the standard 12-month cycle. 
Table 4. Togo: Selected Economic and Financial Indicators, 2003-07

\begin{tabular}{|c|c|c|c|c|c|}
\hline & 2003 & 2004 & 2005 & 2006 & 2007 \\
\hline & \multicolumn{3}{|c|}{ Actual } & Estimate & $\overline{\text { Projection }^{1}}$ \\
\hline & \multicolumn{5}{|c|}{ (Percent change, unless otherwise indicated) } \\
\hline \multicolumn{6}{|l|}{ National income, prices, and exchange rates } \\
\hline Real GDP & 5.2 & 2.3 & 1.2 & 2.0 & 2.9 \\
\hline Real GDP per capita & 2.4 & -0.3 & -1.3 & -0.5 & 0.4 \\
\hline GDP deflator & -9.9 & 2.8 & 7.4 & 2.1 & 2.0 \\
\hline Consumer price index (annual average) & -0.9 & 0.4 & 6.8 & 2.2 & 3.2 \\
\hline GDP (CFAF billions) & 972.7 & $1,023.3$ & $1,112.7$ & $1,158.8$ & $1,216.3$ \\
\hline Exchange rate CFAF/US\$ (annual average) & 580.1 & 527.5 & 527.0 & 524.4 & $\ldots$ \\
\hline Real effective exchange rate (annual average) & 3.7 & 1.1 & 2.5 & -1.4 & $\ldots$ \\
\hline Terms of trade (deterioration -) & 3.7 & -12.2 & -3.6 & -2.9 & $\ldots$ \\
\hline \multicolumn{6}{|l|}{ Monetary survey } \\
\hline Net foreign assets ${ }^{2}$ & 0.6 & 27.0 & -2.8 & 19.2 & 0.0 \\
\hline Credit to government ${ }^{2}$ & -7.4 & -3.6 & -1.2 & -0.7 & 6.5 \\
\hline Credit to the nongovernment sector ${ }^{2}$ & 16.1 & 2.8 & 6.6 & 0.4 & 2.5 \\
\hline Broad money (M2) & 11.4 & 18.3 & 1.4 & 22.1 & 9.0 \\
\hline \multirow[t]{2}{*}{ Velocity (GDP/ end-of-period M2) } & 3.6 & 3.2 & 3.5 & 3.0 & 2.8 \\
\hline & \multicolumn{5}{|c|}{ (Percent of GDP, unless otherwise indicated) } \\
\hline \multicolumn{6}{|l|}{ Investment and savings } \\
\hline Gross domestic investment & 10.8 & 11.1 & 11.8 & 13.0 & 13.7 \\
\hline Government & 1.1 & 1.5 & 2.8 & 3.6 & 3.6 \\
\hline Nongovernment & 9.8 & 9.5 & 9.1 & 9.4 & 10.1 \\
\hline Gross national savings & 6.6 & 8.1 & 6.5 & 7.0 & 7.3 \\
\hline Government & 3.5 & 2.5 & 0.3 & 0.8 & 1.1 \\
\hline Nongovernment & 3.1 & 5.6 & 6.2 & 6.2 & 6.3 \\
\hline \multicolumn{6}{|l|}{ Government budget } \\
\hline Total revenue and grants & 17.6 & 17.5 & 16.9 & 18.3 & 19.0 \\
\hline Revenue & 17.0 & 16.8 & 15.7 & 16.9 & 16.5 \\
\hline Total expenditure and net lending & 15.1 & 16.6 & 19.3 & 21.1 & 21.6 \\
\hline Domestic primary expenditure & 12.5 & 13.6 & 16.2 & 18.0 & 16.9 \\
\hline Overall balance (payment order basis) & 2.4 & 1.0 & -2.4 & -2.8 & -2.5 \\
\hline Primary balance ${ }^{3}$ & 4.5 & 3.2 & -0.5 & -1.1 & -0.4 \\
\hline Change in domestic arrears & 0.3 & 0.5 & 1.9 & -0.4 & 0.0 \\
\hline \multicolumn{6}{|l|}{ External sector } \\
\hline Current account balance & -4.2 & -3.0 & -5.3 & -6.0 & -6.4 \\
\hline Exports (goods and services) & 43.3 & 41.2 & 40.3 & 40.5 & 40.6 \\
\hline Imports (goods and services) & 57.3 & 56.2 & 57.2 & 60.1 & 61.5 \\
\hline External public debt & 93.3 & 86.2 & 80.8 & 80.5 & 72.3 \\
\hline Of which: arrears & 25.7 & 24.3 & 25.8 & 25.6 & 0.0 \\
\hline External public debt service (percent of exports) & 12.8 & 13.1 & 8.1 & 7.1 & 7.0 \\
\hline Gross international reserves, months of imports & 2.3 & 3.6 & 2.0 & 3.2 & 2.9 \\
\hline
\end{tabular}

Sources: Togolese authorities; and Fund staff estimates and projections.

1 Projection reflects SMP objectives and the 2007 budget. Assumes external arrears rescheduling and relief.

2 Percent of broad money at the beginning of the period.

${ }^{3}$ Revenue minus expenditure, excluding grants, interest, and foreign-financed expenditure. 
Table 5. Togo: Balance of Payments, 2002-10

\begin{tabular}{|c|c|c|c|c|c|c|c|c|c|}
\hline & \multirow[t]{2}{*}{2002} & \multirow[t]{2}{*}{2003} & \multirow[t]{2}{*}{2004} & \multirow[t]{2}{*}{2005} & 2006 & 2007 & 2008 & 2009 & 2010 \\
\hline & & & & & Est. & \multicolumn{4}{|c|}{ Reform scenario $^{1}$} \\
\hline & \multicolumn{9}{|c|}{ (Billions of CFA francs) } \\
\hline Current account balance & -55.8 & -40.8 & -30.2 & -58.9 & -70.1 & -77.6 & -81.1 & -84.6 & -83.0 \\
\hline Trade balance & -105.7 & -91.3 & -133.3 & -182.8 & -224.0 & -249.5 & -275.8 & -298.7 & -315.9 \\
\hline Exports & 295.6 & 347.3 & 317.5 & 314.2 & 319.8 & 333.0 & 358.5 & 388.4 & 424.1 \\
\hline Of which: Cotton & 27.6 & 51.8 & 42.1 & 33.9 & 20.4 & 13.5 & 24.9 & 27.3 & 28.8 \\
\hline Phosphates & 28.7 & 20.5 & 25.4 & 18.1 & 20.3 & 19.6 & 32.0 & 33.3 & 34.6 \\
\hline Cement \& clinker & 51.8 & 72.0 & 61.7 & 52.8 & 54.2 & 60.2 & 64.7 & 68.2 & 72.3 \\
\hline Reexports & 77.6 & 85.4 & 41.7 & 44.5 & 55.7 & 63.4 & 65.9 & 72.3 & 78.3 \\
\hline \multirow{3}{*}{$\begin{array}{l}\text { Imports, f.o.b. } \\
\text { Of which: Petroleum products } \\
\text { Imports for reexports }\end{array}$} & -401.3 & -438.6 & -450.8 & -497.0 & -543.8 & -582.5 & -634.3 & -687.1 & -740.0 \\
\hline & -103.9 & -109.3 & -132.6 & -182.6 & -213.6 & -226.5 & -231.2 & -241.1 & -252.4 \\
\hline & -68.1 & -74.9 & -33.3 & -35.6 & -47.0 & -55.8 & -58.0 & -63.7 & -68.9 \\
\hline Services (net) & -23.4 & -44.4 & -20.3 & -5.0 & -3.0 & -4.3 & 0.2 & 5.5 & 7.9 \\
\hline \multirow{2}{*}{$\begin{array}{l}\text { Credit } \\
\text { Debit }\end{array}$} & 79.8 & 74.3 & 103.6 & 134.2 & 149.1 & 161.0 & 177.1 & 194.8 & 210.4 \\
\hline & -103.2 & -118.7 & -123.9 & -139.2 & -152.1 & -165.4 & -176.9 & -189.3 & -202.6 \\
\hline Income (net) & -15.1 & -13.6 & -17.7 & -9.4 & -13.2 & -17.3 & -12.4 & -12.2 & -12.1 \\
\hline Current transfers (net) & 88.3 & 108.4 & 141.1 & 138.3 & 170.2 & 193.5 & 206.9 & 220.8 & 237.1 \\
\hline Private & 84.8 & 102.9 & 133.2 & 125.2 & 154.2 & 161.9 & 165.8 & 170.4 & 175.0 \\
\hline Public & 3.5 & 5.5 & 7.9 & 13.1 & 16.0 & 31.6 & 41.1 & 50.4 & 62.1 \\
\hline Capital and financial account & 25.0 & 1.3 & 31.8 & 7.6 & 101.2 & 30.6 & 40.2 & 50.5 & -219.2 \\
\hline \multirow{2}{*}{$\begin{array}{l}\text { Direct investment } \\
\text { Portfolio investment, incl. bond }\end{array}$} & 35.5 & 23.3 & 38.0 & 24.2 & 39.8 & 30.1 & 42.4 & 54.5 & 65.0 \\
\hline & 9.1 & 9.7 & 15.7 & 12.7 & 33.7 & 0.0 & 0.0 & 0.0 & 0.0 \\
\hline Other investment & -19.7 & -31.7 & -21.9 & -29.3 & 27.7 & 0.5 & -2.2 & -4.0 & -284.2 \\
\hline General government & -23.9 & -30.4 & -28.6 & -9.5 & -10.1 & -7.7 & -6.5 & -3.7 & -275.1 \\
\hline Disbursements & 7.9 & 3.3 & 4.9 & 9.9 & 9.5 & 14.6 & 18.0 & 21.8 & 23.1 \\
\hline Amortization & -31.8 & -33.6 & -33.5 & -19.4 & -19.6 & -22.3 & -24.5 & -25.5 & -298.2 \\
\hline Banks, net foreign assets ${ }^{2}$ & 0.0 & 5.32 & -25.3 & -13.5 & -2.2 & 0.0 & 0.0 & 0.0 & 0.0 \\
\hline Other capital, errors, and omissions & 4.2 & -6.7 & 32.0 & -6.3 & 40.0 & 8.2 & 4.4 & -0.3 & -9.1 \\
\hline Overall balance & -30.8 & -39.5 & 1.6 & -51.3 & 31.1 & -47.1 & -40.9 & -34.1 & -302.1 \\
\hline Financing & 30.8 & 39.5 & -1.6 & 51.3 & -31.1 & 31.4 & 9.4 & 11.9 & 283.9 \\
\hline Central bank net foreign assets ${ }^{2}$ & -14.0 & -6.7 & -47.1 & 22.3 & -59.4 & 0.0 & -11.4 & -13.1 & -14.0 \\
\hline Of which: Use of Fund resources & -5.5 & -7.0 & -8.5 & -6.0 & -3.6 & -3.3 & -0.8 & 0.0 & 0.0 \\
\hline Arrears, net change & 44.9 & 46.3 & 45.4 & 29.0 & 28.3 & 31.4 & 0.0 & 0.0 & 0.0 \\
\hline Rescheduling obtained & 0.0 & 0.0 & 0.0 & 0.0 & 0.0 & 250.4 & 20.8 & 25.0 & 25.7 \\
\hline Debt cancellation $^{3}$ & 0.0 & 0.0 & 0.0 & 0.0 & 0.0 & 77.1 & 0.0 & 0.0 & 272.1 \\
\hline Arrears clearance & $\cdots$ & $\cdots$ & $\ldots$ & $\ldots$ & $\ldots$ & -327.5 & $\ldots$ & $\ldots$ & $\ldots$ \\
\hline Unidentified financing & 0.0 & 0.0 & 0.0 & 0.0 & 0.0 & 15.6 & 31.5 & 22.2 & 18.3 \\
\hline Memorandum items: & & & (Percent & of GDP, & Inless oth & rwise ind & icated) & & \\
\hline Current account balance & -5.4 & -4.2 & -3.0 & -5.3 & -6.0 & -6.4 & -6.3 & -6.2 & -5.7 \\
\hline Exports of goods and services & 36.6 & 43.3 & 41.2 & 40.3 & 40.5 & 40.6 & 41.7 & 42.8 & 43.9 \\
\hline Imports of goods and services & 49.1 & 57.3 & 56.2 & 57.2 & 60.1 & 61.5 & 63.2 & 64.3 & 65.2 \\
\hline Gross int. reserves, months of imports & 2.6 & 2.3 & 3.6 & 2.0 & 3.2 & 2.9 & 2.9 & 2.8 & 2.8 \\
\hline
\end{tabular}

Sources: Togolese authorities; and Fund staff estimates and projections.

${ }^{1}$ Based on structural reforms, fiscal adjustment, and higher donor support. Assumes external debt and arrears rescheduling/relief in 2007-10, broadly in line with potential debt relief under the HIPC initiative and MDRI.

${ }^{2}$ Negative sign indicates increase.

${ }^{3}$ Debt cancellation in 2007 refers to potential grant-based clearance of arrears. 
Table 6. Togo: Financial Operation of the Central Government, 2005-10

\begin{tabular}{|c|c|c|c|c|c|c|c|}
\hline & \multirow{2}{*}{$\frac{2005}{\text { Actual }}$} & \multirow{2}{*}{$\frac{2006}{\text { Actual }}$} & \multicolumn{2}{|c|}{2007} & 2008 & 2009 & 2010 \\
\hline & & & $\mathrm{H} 1$ & Proj. $^{1}$ & \multicolumn{3}{|c|}{ Reform scenario $^{1}$} \\
\hline & \multicolumn{7}{|c|}{ (Billions of CFA francs) } \\
\hline Revenue and grants & 188.0 & 211.9 & 111.9 & 231.7 & 259.4 & 290.1 & 322.2 \\
\hline Total revenue & 174.9 & 195.9 & 95.0 & 200.1 & 218.3 & 239.7 & 260.1 \\
\hline Tax revenue & 162.1 & 179.1 & 90.0 & 185.1 & 201.3 & 220.8 & 238.5 \\
\hline Tax administration (DGI) & 81.0 & 86.8 & 43.0 & 87.6 & 97.3 & 106.7 & 117.5 \\
\hline Customs administration (DGD) & 81.0 & 92.3 & 47.0 & 97.5 & 104.0 & 114.1 & 121.0 \\
\hline Nontax revenue & 12.8 & 16.8 & 5.0 & 15.0 & 17.0 & 18.9 & 21.6 \\
\hline Grants & 13.1 & 16.0 & 16.9 & 31.6 & 41.1 & 50.4 & 62.1 \\
\hline Expenditures and net lending & 215.0 & 244.2 & 131.9 & 262.7 & 292.3 & 320.1 & 348.8 \\
\hline Current expenditures & 184.1 & 202.5 & 111.2 & 218.5 & 220.4 & 231.5 & 246.2 \\
\hline Domestic primary current expenditures & 166.8 & 184.7 & 93.6 & 185.6 & 193.9 & 204.3 & 218.2 \\
\hline Wages and salaries & 49.2 & 59.3 & 31.0 & 63.9 & 70.6 & 80.4 & 91.0 \\
\hline Goods and services & 46.9 & 66.7 & 26.7 & 52.8 & 53.3 & 53.4 & 52.2 \\
\hline Subsidies and transfers & 26.6 & 44.0 & 28.3 & 51.7 & 49.8 & 53.7 & 58.0 \\
\hline Of which: to clear SOTOCO arrears & $\ldots$ & 10.4 & 6.0 & 6.0 & 0.0 & 0.0 & 0.0 \\
\hline Autonomous and local entities & 8.2 & 5.1 & 2.2 & 5.2 & 6.5 & 6.9 & 7.0 \\
\hline Offbudget/unclassified & 35.9 & 9.6 & 4.5 & 7.0 & 3.9 & 0.0 & 0.0 \\
\hline Bank restructuring/other contingency & 0.0 & 0.0 & 1.0 & 5.0 & 9.9 & 9.9 & 9.9 \\
\hline Foreign-financed current expenditures & 5.7 & 7.3 & 12.0 & 21.7 & 10.3 & 10.9 & 11.6 \\
\hline Interest & 11.6 & 10.5 & 5.6 & 11.1 & 16.2 & 16.3 & 16.4 \\
\hline Domestic debt & 0.7 & 0.5 & 1.0 & 2.0 & 3.9 & 4.1 & 4.3 \\
\hline External debt & 10.9 & 10.0 & 4.6 & 9.1 & 12.4 & 12.2 & 12.1 \\
\hline Public investment & 30.9 & 41.6 & 20.7 & 44.2 & 71.9 & 88.5 & 102.6 \\
\hline Domestically financed & 13.6 & 23.5 & 8.5 & 19.7 & 23.1 & 27.2 & 28.9 \\
\hline Externally financed & 17.3 & 18.2 & 12.2 & 24.5 & 48.8 & 61.3 & 73.7 \\
\hline Domestic primary balance & -5.5 & -12.3 & -7.0 & -5.2 & 1.3 & 8.2 & 13.0 \\
\hline Overall balance, payment order basis & -27.0 & -32.3 & -19.9 & -31.0 & -32.9 & -29.9 & -26.6 \\
\hline Change in arrears and treasury float & 31.1 & 4.2 & 4.6 & 9.1 & -6.4 & -6.8 & -7.2 \\
\hline Change in domestic arrears and treasury float & 20.7 & -5.2 & 0.0 & 0.0 & -6.4 & -6.8 & -7.2 \\
\hline Arrears on external interest & 10.4 & 9.4 & 4.6 & 9.1 & 0.0 & 0.0 & 0.0 \\
\hline Overall balance, cash basis & 4.1 & -28.1 & -15.3 & -21.8 & -39.4 & -36.7 & -33.8 \\
\hline Financing & 1.8 & 33.1 & 15.3 & 6.2 & 7.9 & 14.5 & 15.5 \\
\hline Domestic financing (net) & -7.3 & 24.8 & 9.7 & -4.9 & -6.4 & -6.8 & -7.2 \\
\hline Banking system & -3.7 & -17.8 & 13.2 & 22.2 & 0.5 & 0.1 & -0.3 \\
\hline Of which: IMF & -6.0 & -3.6 & -1.6 & -3.3 & -0.8 & 0.0 & 0.0 \\
\hline central bank & 6.1 & -17.1 & 13.8 & 24.2 & 1.3 & 0.1 & -0.3 \\
\hline commercial banks & -3.8 & 2.9 & 1.0 & 1.3 & 0.0 & 0.0 & 0.0 \\
\hline Nonbank financing ${ }^{2}$ & 4.1 & 49.8 & 0.0 & -20.2 & 0.0 & 0.0 & 0.0 \\
\hline Amortization of NPLs guaranteed by govt. & -7.7 & -7.2 & -3.5 & -6.9 & -6.9 & -6.9 & -6.9 \\
\hline External financing (net) & 9.1 & 8.3 & 5.6 & 11.1 & 14.3 & 21.3 & 22.8 \\
\hline Drawings & 9.9 & 9.5 & 7.3 & 14.6 & 18.0 & 21.8 & 23.1 \\
\hline Amortization & -19.4 & -19.6 & -11.1 & -22.3 & -24.5 & -25.5 & -298.2 \\
\hline Rescheduling obtained & 0.0 & 0.0 & 0.0 & 250.4 & 20.8 & 25.0 & 25.7 \\
\hline Debt cancellation ${ }^{3}$ & 0.0 & 0.0 & 0.0 & 77.1 & 0.0 & 0.0 & 272.1 \\
\hline Arrears on amortization & 18.6 & 18.4 & 11.1 & 22.3 & 0.0 & 0.0 & 0.0 \\
\hline Arrears clearance & $\ldots$ & $\ldots$ & $\ldots$ & -327.5 & $\ldots$ & $\ldots$ & $\ldots$ \\
\hline Contingency for debt service & $\ldots$ & 0.0 & -1.7 & -3.5 & 0.0 & 0.0 & 0.0 \\
\hline Discrepancy/unidentified financing & -5.8 & -5.0 & 0.0 & 15.6 & 31.5 & 22.2 & 18.3 \\
\hline
\end{tabular}


Table 6. Togo: Financial Operation of the Central Government, 2005-10 (concluded)

\begin{tabular}{|c|c|c|c|c|c|c|c|}
\hline & \multirow{2}{*}{$\frac{2005}{\text { Actual }}$} & \multirow{2}{*}{$\frac{2006}{\text { Actual }}$} & \multicolumn{2}{|c|}{2007} & 2008 & 2009 & 2010 \\
\hline & & & $\mathrm{H} 1$ & Proj. ${ }^{1}$ & \multicolumn{3}{|c|}{ Reform scenario $^{1}$} \\
\hline & \multicolumn{7}{|c|}{ (Percent of GDP, unless otherwise indicated) } \\
\hline Revenue and grants & 16.9 & 18.3 & 9.2 & 19.0 & 20.2 & 21.3 & 22.3 \\
\hline Total revenue & 15.7 & 16.9 & 7.8 & 16.5 & 17.0 & 17.6 & 18.0 \\
\hline Tax revenue & 14.6 & 15.5 & 7.4 & 15.2 & 15.7 & 16.2 & 16.5 \\
\hline Nontax revenue & 1.1 & 1.4 & 0.4 & 1.2 & 1.3 & 1.4 & 1.5 \\
\hline Grants & 1.2 & 1.4 & 1.4 & 2.6 & 3.2 & 3.7 & 4.3 \\
\hline Expenditures and net lending & 19.3 & 21.1 & 10.8 & 21.6 & 22.8 & 23.5 & 24.1 \\
\hline Current expenditures & 16.5 & 17.5 & 9.1 & 18.0 & 17.2 & 17.0 & 17.0 \\
\hline Domestic primary current expenditures & 15.0 & 15.9 & 7.7 & 15.3 & 15.1 & 15.0 & 15.1 \\
\hline Wages and salaries & 4.4 & 5.1 & 2.5 & 5.3 & 5.5 & 5.9 & 6.3 \\
\hline Goods and services & 4.2 & 5.8 & 2.2 & 4.3 & 4.1 & 3.9 & 3.6 \\
\hline Subsidies and transfers & 2.4 & 3.8 & 2.3 & 4.3 & 3.9 & 3.9 & 4.0 \\
\hline Autonomous and local entities & 0.7 & 0.4 & 0.2 & 0.4 & 0.5 & 0.5 & 0.5 \\
\hline Offbudget/unclassified & 3.2 & 0.8 & 0.4 & 0.6 & 0.3 & 0.0 & 0.0 \\
\hline Bank restructuring/other contingency & 0.0 & 0.0 & $\ldots$ & 0.4 & 0.8 & 0.7 & 0.7 \\
\hline Foreign-financed current expenditures & 0.5 & 0.6 & 1.0 & 1.8 & 0.8 & 0.8 & 0.8 \\
\hline Interest & 1.0 & 0.9 & 0.5 & 0.9 & 1.3 & 1.2 & 1.1 \\
\hline External debt & 1.0 & 0.9 & 0.4 & 0.8 & 1.0 & 0.9 & 0.8 \\
\hline Public investment & 2.8 & 3.6 & 1.7 & 3.6 & 5.6 & 6.5 & 7.1 \\
\hline Domestically financed & 1.2 & 2.0 & 0.7 & 1.6 & 1.8 & 2.0 & 2.0 \\
\hline Externally financed & 1.6 & 1.6 & 1.0 & 2.0 & 3.8 & 4.5 & 5.1 \\
\hline Domestic primary balance & -0.5 & -1.1 & -0.6 & -0.4 & 0.1 & 0.6 & 0.9 \\
\hline Overall balance, payment order basis & -2.4 & -2.8 & -1.6 & -2.5 & -2.6 & -2.2 & -1.8 \\
\hline Change in domestic arrears and treasury float & 1.9 & -0.4 & 0.0 & 0.0 & -0.5 & -0.5 & -0.5 \\
\hline Arrears on external interest & 0.9 & 0.8 & 0.4 & 0.8 & 0.0 & 0.0 & 0.0 \\
\hline Overall balance, cash basis & 0.4 & -2.4 & -1.3 & -1.8 & -3.1 & -2.7 & -2.3 \\
\hline Financing & 0.2 & 2.9 & 1.3 & 0.5 & 0.6 & 1.1 & 1.1 \\
\hline Domestic financing (net) & -0.7 & 2.1 & 0.8 & -0.4 & -0.5 & -0.5 & -0.5 \\
\hline Banking system & -0.3 & -1.5 & 1.1 & 1.8 & 0.0 & 0.0 & 0.0 \\
\hline Nonbank financing ${ }^{2}$ & 0.4 & 4.3 & 0.0 & -1.7 & 0.0 & 0.0 & 0.0 \\
\hline Amortization of NPLs guaranteed by govt. & -0.7 & -0.6 & -0.3 & -0.6 & -0.5 & -0.5 & -0.5 \\
\hline External financing (net) & 0.8 & 0.7 & 0.5 & 0.9 & 1.1 & 1.6 & 1.6 \\
\hline Drawings & 0.9 & 0.8 & 0.6 & 1.2 & 1.4 & 1.6 & 1.6 \\
\hline Amortization & -1.7 & -1.7 & -0.9 & -1.8 & -1.9 & -1.9 & -20.6 \\
\hline Rescheduling obtained & 0.0 & 0.0 & 0.0 & 20.6 & 1.6 & 1.8 & 1.8 \\
\hline Debt cancellation ${ }^{3}$ & 0.0 & 0.0 & 0.0 & 6.3 & 0.0 & 0.0 & 18.8 \\
\hline Arrears on amortization & 1.7 & 1.6 & 0.9 & 1.8 & 0.0 & 0.0 & 0.0 \\
\hline Contingency for debt service & $\cdots$ & 0.0 & -0.1 & -0.3 & 0.0 & 0.0 & 0.0 \\
\hline Discrepancy/unidentified financing & -0.5 & -0.4 & 0.0 & 1.3 & 2.5 & 1.6 & 1.3 \\
\hline \multicolumn{8}{|l|}{ Memorandum items } \\
\hline Social spending ${ }^{4}$ & 5.1 & 6.2 & $\ldots$ & 6.4 & 7.8 & 9.4 & 11.3 \\
\hline Of which : foreign financed & 1.1 & 0.8 & $\cdots$ & 1.1 & 2.3 & 3.0 & 3.8 \\
\hline Nominal GDP (CFAF billions) & 1,113 & 1,159 & 1,216 & 1,216 & 1,284 & 1,362 & 1,445 \\
\hline
\end{tabular}

Sources: Togolese authorities; and Fund staff estimates and projections.

1 Projections for 2007 based on SMP objectives and 2007 budget. Assumes external debt and arrears rescheduling/relief in 2007-10, broadly in line with potential debt relief under the HIPC initiative and MDRI.

${ }^{2}$ Includes issuance of government bond on the regional market and changes in suspense accounts.

${ }^{3}$ Debt cancellation in 2007 refers to potential grant-based clearance of arrears.

${ }^{4}$ Includes health and education (including salaries), and pension transfers. 
Table 7. Togo: Monetary Survey, 2005-07

\begin{tabular}{|c|c|c|c|c|c|}
\hline & \multirow{2}{*}{$\frac{2005}{\text { Dec. }}$} & \multicolumn{3}{|c|}{2006} & \multirow{2}{*}{$\begin{array}{c}2007 \\
\text { Dec. } \\
\text { Proj. }{ }^{1}\end{array}$} \\
\hline & & June & Sept & Dec. & \\
\hline & \multicolumn{5}{|c|}{ (Billions of CFA francs) } \\
\hline Net foreign assets & 145.1 & 203.2 & 209.7 & 206.7 & 206.7 \\
\hline BCEAO & 91.9 & 153.2 & 155.2 & 151.3 & 151.3 \\
\hline Assets & 108.2 & 180.5 & 201.5 & 185.0 & 181.9 \\
\hline Liabilities & 16.3 & 27.2 & 46.4 & 33.7 & 30.5 \\
\hline Commercial banks & 53.2 & 50.0 & 54.6 & 55.4 & 55.4 \\
\hline Assets & 92.1 & 90.2 & 94.3 & 91.3 & 91.3 \\
\hline Liabilities & 38.9 & 40.2 & 39.7 & 35.9 & 35.9 \\
\hline Net domestic assets & 176.6 & 143.2 & 161.1 & 186.1 & 221.4 \\
\hline Credit to the government (net) & 12.0 & 10.4 & 12.9 & 9.8 & 35.3 \\
\hline BCEAO & 7.1 & -21.9 & -12.9 & -13.6 & 10.6 \\
\hline Commercial banks & 5.0 & 32.3 & 25.9 & 23.4 & 24.7 \\
\hline Credit to the rest of the economy & 195.1 & 165.4 & 175.0 & 196.2 & 206.0 \\
\hline Other items (net) & -30.5 & -32.6 & -26.8 & -19.9 & -19.9 \\
\hline Money supply (M2) & 321.7 & 346.4 & 370.8 & 392.8 & 428.3 \\
\hline Currency in circulation & 63.2 & 70.1 & 82.1 & 100.1 & 92.1 \\
\hline \multirow[t]{2}{*}{ Bank deposits } & 258.5 & 276.3 & 288.8 & 292.7 & 336.2 \\
\hline & \multicolumn{5}{|c|}{ (Annual change, percent of beginning-of-period broad money) } \\
\hline Net foreign assets & -2.8 & 18.1 & 20.1 & 19.2 & 0.0 \\
\hline BCEAO & -7.0 & 19.1 & 19.7 & 18.5 & 0.0 \\
\hline Commercial banks & 4.3 & -1.0 & 0.4 & 0.7 & 0.0 \\
\hline Net domestic assets & 4.2 & -10.4 & -4.8 & 2.9 & 9.0 \\
\hline Credit to the government (net) & -1.2 & -0.5 & 0.3 & -0.7 & 6.5 \\
\hline Credit to the rest of the economy & 6.6 & -9.2 & -6.2 & 0.4 & 2.5 \\
\hline Other items (net) & -1.2 & -0.7 & 1.2 & 3.3 & 0.0 \\
\hline Money supply (M2) & 1.4 & 7.7 & 15.3 & 22.1 & 9.0 \\
\hline Currency in circulation & -3.2 & 2.1 & 5.9 & 11.5 & -2.0 \\
\hline Bank deposits & 4.6 & 5.5 & 9.4 & 10.6 & 11.1 \\
\hline \multicolumn{6}{|l|}{ Memorandum items } \\
\hline Velocity (GDP/ end-of-period M2) & 3.5 & $\ldots$ & $\ldots$ & 3.0 & 2.8 \\
\hline
\end{tabular}

Sources: Central Bank of West African States, and Fund staff estimates and projections.

${ }^{1}$ Based on SMP objectives. 
Table 8. Togo: Official External Debt, 2004-06

\begin{tabular}{|c|c|c|c|c|c|c|}
\hline & \multicolumn{2}{|c|}{2004} & \multicolumn{2}{|c|}{2005} & \multicolumn{2}{|c|}{2006 (Prel.) } \\
\hline & \multirow{2}{*}{ Total } & \multirow[b]{2}{*}{$\begin{array}{r}\text { Of which: } \\
\text { arrears }\end{array}$} & Total & & Total & \\
\hline & & & \multicolumn{2}{|c|}{$\begin{array}{r}\text { Of which: } \\
\text { arrears }\end{array}$} & \multicolumn{2}{|r|}{$\begin{array}{r}\text { Of which: } \\
\text { arrears }\end{array}$} \\
\hline & \multicolumn{6}{|c|}{ (Millions of U.S. dollars) } \\
\hline Total & $1,600.3$ & 336.7 & $1,625.8$ & 367.6 & $1,819.7$ & 577.3 \\
\hline Multilateral & 967.3 & 78.0 & 906.4 & 123.6 & $1,032.1$ & 157.9 \\
\hline World Bank & 731.0 & 59.1 & 666.9 & 67.0 & 715.3 & 104.5 \\
\hline AfDB & 133.6 & 10.2 & 116.2 & 12.1 & 128.6 & 15.4 \\
\hline Other & 102.7 & 36.4 & 123.3 & 25.3 & 188.3 & 38.0 \\
\hline Bilateral & 632.7 & 258.4 & 719.4 & 243.7 & 787.6 & 419.4 \\
\hline Paris Club & 506.0 & 174.3 & 579.3 & 218.5 & 687.7 & 404.0 \\
\hline \multirow[t]{2}{*}{ Non-Paris Club } & 126.7 & 84.2 & 140.1 & 25.2 & 99.9 & 15.4 \\
\hline & \multicolumn{6}{|c|}{ (Percent of GDP, unless otherwise indicated) } \\
\hline Total & 86.2 & 24.3 & 80.8 & 25.8 & 80.5 & 25.6 \\
\hline Multilateral & 48.6 & 5.1 & 45.1 & 6.4 & 45.7 & 7.0 \\
\hline World Bank & 34.9 & 2.8 & 33.2 & 4.0 & 31.7 & 4.6 \\
\hline AfDB & 6.4 & 0.5 & 5.8 & 0.9 & 5.7 & 0.7 \\
\hline Other & 7.3 & 1.7 & 6.1 & 1.4 & 8.3 & 1.7 \\
\hline Bilateral & 37.6 & 19.2 & 35.8 & 19.4 & 34.9 & 18.6 \\
\hline Paris Club & 30.1 & 17.7 & 28.8 & 17.4 & 30.4 & 17.9 \\
\hline Non-Paris Club & 7.5 & 1.5 & 7.0 & 2.0 & 4.4 & 0.7 \\
\hline \multicolumn{7}{|l|}{ Memorandum item } \\
\hline Nominal GDP (CFAF billions) & 1023.3 & & 1112.7 & & 1158.8 & \\
\hline Exchange rate CFAF/USD (end of year) & 489.3 & & 553.3 & & 512.9 & \\
\hline
\end{tabular}

Sources: Togolese authorities, and Fund staff estimates. 
Table 9. Togo: Domestic Government Debt, 2005-06 (CFAF millions)

\begin{tabular}{|c|c|c|c|c|}
\hline \multirow[b]{2}{*}{ Debt category } & \multicolumn{2}{|c|}{2005} & \multicolumn{2}{|c|}{2006} \\
\hline & Total debt & $\begin{array}{l}\text { Of which: } \\
\text { arrears }\end{array}$ & Total debt & $\begin{array}{l}\text { Of which: } \\
\text { arrears }\end{array}$ \\
\hline Commercial debt 1/ & 33,797 & 33,797 & 36,497 & 36,497 \\
\hline of which: subsidies and transfers & 12,419 & - & 12,419 & - \\
\hline Financial debt 2/ & 173,418 & 36,253 & 204,492 & 37,222 \\
\hline of which: CNSS & 82,906 & 16,149 & 87,880 & 17,118 \\
\hline BCEAO & 18,090 & - & 15,390 & - \\
\hline Commercial banks $3 /$ & 53,953 & 1,635 & 46,753 & 1,635 \\
\hline of which: NPL to BTCl 4/ & 23,000 & & 18,800 & \\
\hline NPL to UTB 4/ & 10,474 & & 8,074 & \\
\hline SOES & 18,469 & 18,469 & 18,469 & 18,469 \\
\hline Government bond & & & 36,000 & - \\
\hline Social debt $5 /$ & 5,848 & 5,848 & - & - \\
\hline Deposits at the Treasury 6/ & 17,966 & - & 17,966 & - \\
\hline Total & 231,029 & 75,898 & 258,955 & 73,719 \\
\hline \multicolumn{5}{|l|}{ Memo items } \\
\hline Authorities total domestic debt estimates & 278,374 & & 311,129 & \\
\hline of which: commercial debt & 103,440 & & 99,805 & \\
\hline other commercial debt & 16,129 & & 16,130 & \\
\hline financial debt & 113,199 & & 163,383 & \\
\hline other liabilities and overdrafts & 45,606 & & 31,811 & \\
\hline KPMG audit total debt & 318,555 & & & \\
\hline of which: validated & 231,029 & & & \\
\hline pending & 6,520 & & & \\
\hline non verifiable & 14,040 & & & \\
\hline rejected & 66,966 & & & \\
\hline
\end{tabular}

Sources: Preliminary results of debt KPMG audit (2005 data); Togolese authorities; and Fund staff estimates.

$1 /$ Includes delivery or goods or services rendered by private suppliers, mostly in arrears.

$2 /$ Includes borrowing from commercial banks and state-owned enterprises.

3 / Includes subscription of government bond of CFAF 36 bn in 2006 by domestic and foreign banks.

$4 /$ Includes nonperforming loans to state-owned enterprises taken over by the state.

$5 /$ Includes arrears on wages and social contributions.

6/ Includes deposit accounts of public agencies, local administrations, and private and public companies with the Treasury. 


\section{SUPPLEMENT I-Joint World Bank/IMF Debt Sustainability Analysis}

This debt sustainability analysis (DSA), prepared jointly by the staffs of the IMF and the World Bank, applies the low-income country template to the staff's projections under a noreform scenario and a reform scenario, the latter also factoring in potential debt relief under the Enhanced HIPC Initiative and MDRI. The analysis shows that Togo is in debt distress, with large arrears to the World Bank and other official creditors and NPV-of-debt ratios projected to remain well above the country-specific thresholds over the long term. The reform scenario illustrates the potential gains associated with possible debt relief, fiscal adjustment, and economic reforms. Different stress tests indicate that public and external debt would remain sustainable under the reform scenario; in the absence of fiscal and structural reforms, however, key debt indicators would revert to an unsustainable path.

\section{Introduction}

1. Togo is currently participating in a staff-monitored program (SMP) with the IMF, which could lead to a Fund-supported program under the Poverty-Reduction and Growth Facility (PRGF) and, eventually, debt relief under the Enhanced HIPC Initiative and MDRI. ${ }^{1}$ The staffs have therefore prepared two scenarios, a no-reform scenario characterized by low growth and high fiscal deficits, and a reform scenario describing an economic recovery supported by structural reforms, higher external assistance, and potential debt relief. The former scenario is used to determine the extent of Togo's debt burden. The latter scenario illustrates the potential impact of reforms and debt relief and is used to discuss the robustness of the projected debt indicators (post-debt relief) to various shocks.

\section{Current debt situation}

2. Togo's public sector debt, including arrears, was estimated at US\$2.3 billion as of end-2006, corresponding to 103 percent of GDP. External debt was estimated at US\$ 1.8 billion ( 81 percent of GDP), of which the World Bank and Paris Club creditors account for the lion's share, with about US $\$ 0.7$ billion each. Arrears now account for almost a third of total external debt. Togo's debt to the IMF is relatively modest (US $\$ 8.2$ million as of end-2006), and it is current on this debt. While public debt has been declining since 2000, this occurred mainly because the CFA franc (pegged to the euro) has appreciated against the

\footnotetext{
${ }^{1}$ Togo belongs to the "ring-fenced" countries that met the end-2004 income and indebtedness criteria under the Enhanced HIPC Initiative and would potentially be eligible for debt relief under the Enhanced HIPC Initiative and MDRI. With domestic revenues exceeding 15 percent of GDP, and an export-GDP ratio exceeding 30 percent, Togo would qualify for debt relief under the Enhanced HIPC Initiative under the "fiscal window;" and a NPV of debt-to-revenue threshold of 250 percent would apply.
} 
U.S. dollar and other currencies. ${ }^{2}$ Without this appreciation, debt-to-GDP ratio would have been about 20 percent above its current level.

Figure 1. The most important creditors are the World Bank and the Paris Club.

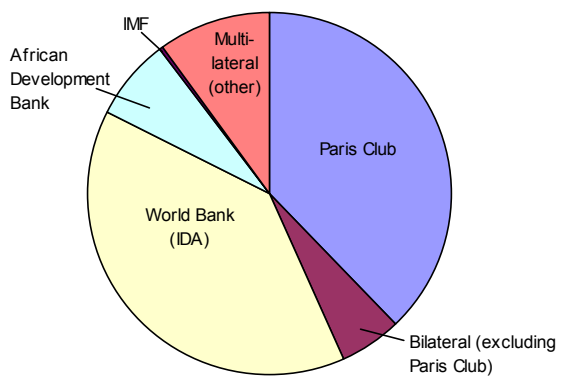

Figure 2. About one-third of Togo's external debt is in arrears.

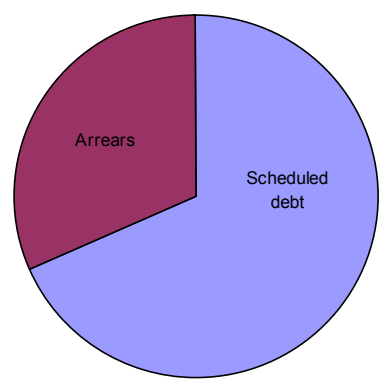

3. Togo is in debt distress. Togo is in arrears to the World Bank, the African Development Bank, and other multilateral and bilateral creditors (but not the IMF). At end2006, the net present value (NPV) of external debt to exports ratio was estimated at 162 percent, and the ratio of the NPV of debt to revenue at 388 percent, in both cases well above the applicable indicative thresholds (Table 1). Moreover, because Togo has not serviced most of its external debt in recent years, arrears on principal and interest have accumulated rapidly and now account for a substantial proportion of overall debt (Figure 2). The indicators of debt service relative to exports or domestic revenues are below the applicable thresholds, partly because a substantial proportion of debt is in arrears. ${ }^{3}$

\footnotetext{
${ }^{2}$ Between end-2000 and end-2006, the CFA franc appreciated against the U.S. dollar by 42 percent, from 729 CFA francs per U.S. dollar to 513 CFA francs per U.S. dollar.

${ }^{3}$ If an imputation for repayment of arrears is included, assuming a 20-year period repayment period and an interest rate of 4 percent, debt service would amount to 11 percent of exports and 26 percent of government revenues (excluding grants) in 2006, the latter exceeding the applicable indicative threshold.
} 
Table 1. Togo: Key External Debt Sustainability Indicators (Percent) ${ }^{1}$ (No-reform scenario)

\begin{tabular}{lccc}
\hline & $\begin{array}{c}\text { Indicative } \\
\text { Threshold }\end{array}$ & $\begin{array}{c}2006 \\
\text { (Est.) }\end{array}$ & $\begin{array}{c}2027 \\
\text { (Proj.) }\end{array}$ \\
\hline NPV of debt to GDP & 30 & 65.6 & 52.6 \\
NPV of debt to exports & 100 & 162.1 & 133.3 \\
NPV of debt to revenue (excl. grants) & 200 & 387.9 & 329.5 \\
Debt service to exports & 15 & 7.1 & 8.3 \\
Debt service to revenue (excl. grants) & 25 & 16.9 & 20.4 \\
\hline
\end{tabular}

\footnotetext{
${ }^{1}$ All debt indicators refer to the NPV of public and publicly guaranteed external debt, and relate to the "no-reform scenario" described in Table 2.

${ }^{2}$ Policy-dependent debt-sustainability threshold over which countries with similar evaluations of policies and institutions would face a probability of about 20 percent of experiencing a prolonged incident of debt distress in the coming year. The thresholds shown relate to low-income countries with poor institutional quality, reflecting Togo's score in the World Bank's Country Policy and Institutional Assessment (CPIA, average 2003-05), which lies within the lowest quintile among the countries covered.
}

\section{Long-term economic macroeconomic outlook}

\section{Togo's growth performance has been very weak, with per capita income} declining since the early 1980s. Political turmoil and weak governance have undermined the investment climate, while access to credit has been hampered by the poor performance of state-owned banks. In the absence of comprehensive economic reforms and increased external assistance, this is unlikely to change. The no-reform scenario (illustrated in Table 2) therefore projects GDP growth to hover around its long-term average of 13/4 percent (below population growth), an overall fiscal deficit exceeding 5 percent of GDP, continued accumulation of arrears, and large external imbalances. In this scenario, debt indicators related to the NPV of debt remain well above the indicative thresholds shown in Table 1 and Figures 6-7. Debt sustainability indicators related to the debt service due remain below the applicable thresholds (see, for example, Fig. 8), largely because a substantial proportion of debt is in arrears, with no debt service scheduled.

5. The more favorable outlook in the reform scenario (Table 2) is based on the implementation of a comprehensive reform program, coupled with increased external assistance and the estimated impact of potential debt relief through the Enhanced HIPC Initiative and MDRI. Real GDP growth rises to around 31/2-4 percent per year, sustained by an increase in foreign direct investment, greater availability of credit to the private sector, and upgrades to critical infrastructure. To achieve this, the scenario envisages an increase in external assistance to 6 percent of GDP (with two-thirds in grants), steps to improve efficiency through improved governance, reallocation of fiscal spending toward public investment; steps to improve the business environment; reform of state-owned enterprises; and banking sector reform. 
Table 2. Togo: Macroeconomic Outlook Under the No-Reform and Reform Scenarios (Percent of GDP, unless otherwise indicated)

\begin{tabular}{|c|c|c|c|c|c|c|}
\hline & \multicolumn{3}{|c|}{ No-Reform Scenario } & \multicolumn{3}{|c|}{ Reform Scenario } \\
\hline & 2007 & 2017 & 2027 & 2007 & 2017 & 2027 \\
\hline \multicolumn{7}{|l|}{ Investment and savings } \\
\hline Real GDP (percent change) & 2.1 & 1.7 & 1.7 & 2.9 & 3.5 & 3.5 \\
\hline Real GDP per capita (percent change) & 0.4 & 0.9 & 0.9 & 1.2 & 2.6 & 2.6 \\
\hline GDP (CFAF billions) & $1,206.8$ & $1,707.4$ & $2,415.6$ & $1,216.3$ & $2,163.2$ & $3,719.6$ \\
\hline \multicolumn{7}{|l|}{ Investment and savings } \\
\hline Gross domestic investment & 12.5 & 12.3 & 12.3 & 13.7 & 22.6 & 22.6 \\
\hline Government & 3.4 & 3.3 & 3.3 & 3.6 & 7.0 & 7.0 \\
\hline Nongovernment & 9.1 & 9.0 & 9.0 & 10.1 & 15.6 & 15.6 \\
\hline Gross national savings & 6.1 & 4.7 & 4.6 & 7.3 & 18.1 & 18.2 \\
\hline Government & 1.1 & -1.9 & -2.1 & 1.1 & 5.5 & 5.6 \\
\hline Nongovernment & 5.0 & 6.5 & 6.7 & 6.3 & 12.6 & 12.6 \\
\hline \multicolumn{7}{|l|}{ Government budget } \\
\hline Total revenue and grants & 17.5 & 17.0 & 17.0 & 19.0 & 22.4 & 22.4 \\
\hline of which: grants & 1.6 & 1.0 & 1.0 & 2.6 & 4.2 & 4.2 \\
\hline Total expenditure and net lending & 21.1 & 22.1 & 22.4 & 21.6 & 23.9 & 23.8 \\
\hline Overall balance (payment order basis) & -3.6 & -5.2 & -5.4 & -2.5 & -1.5 & -1.4 \\
\hline Domestic primary balance & -1.4 & -2.2 & -2.2 & -0.4 & 1.0 & 1.0 \\
\hline \multicolumn{7}{|l|}{ External sector } \\
\hline Current account balance & -6.4 & -7.6 & -7.7 & -6.4 & -4.6 & -4.4 \\
\hline Foreign direct investment & 2.5 & 3.0 & 3.0 & 2.5 & 4.5 & 4.5 \\
\hline
\end{tabular}

Sources: Togolese authorities; and Fund staff estimates and projections.

\section{As a prerequisite for a PRGF arrangement, Togo would have to reach} understandings on the clearance of outstanding arrears on official external debt. In this regard, the EU is preparing several large grants that could be used in part to clear Togo's arrears to the European Investment Bank (about \$20 million). The World Bank staff is preparing a development policy needs review and is examining options for clearing arrears, which stood at about $\$ 105$ million at end-2006. The authorities intend to intensify their dialogue with multilateral creditors and approach the Paris Club to request a rescheduling of bilateral debt and arrears.

\section{Debt Sustainability Analysis}

7. Projections of public debt and debt service under the no-reform scenario show that Togo's public debt is unsustainable in the absence of policy adjustments and debt relief (Figures 3-8, and Tables 3-4). In this scenario, the NPV of total public debt (external and domestic) is projected to rise from 88 percent of GDP in 2006 to 114 percent of GDP in 2027, and from 520 percent of government revenues (excluding grants) to 714 percent (Figures 3-4). Debt service would rise from 15 percent of government revenues (excluding grants) to 25 percent over the same period (Figure 5). A similar picture emerges for external debt. While the NPV of external debt would decline slowly from 388 percent of government 
revenues in 2006 to 329 percent in 2027, it would remain well above the indicative threshold of 200 percent, as illustrated in Figures 6-7. The ratio of the NPV of external debt to exports would also remain above the indicative threshold of 100 percent (falling from 162 percent in 2006 to 133 percent in 2027), while external debt service would increase somewhat (to 8 percent of exports, by 2027).

Figures 3-8. In the no-reform scenario, debt indicators remain well above the applicable thresholds, while the reform scenario with debt relief envisages a very substantial decline.
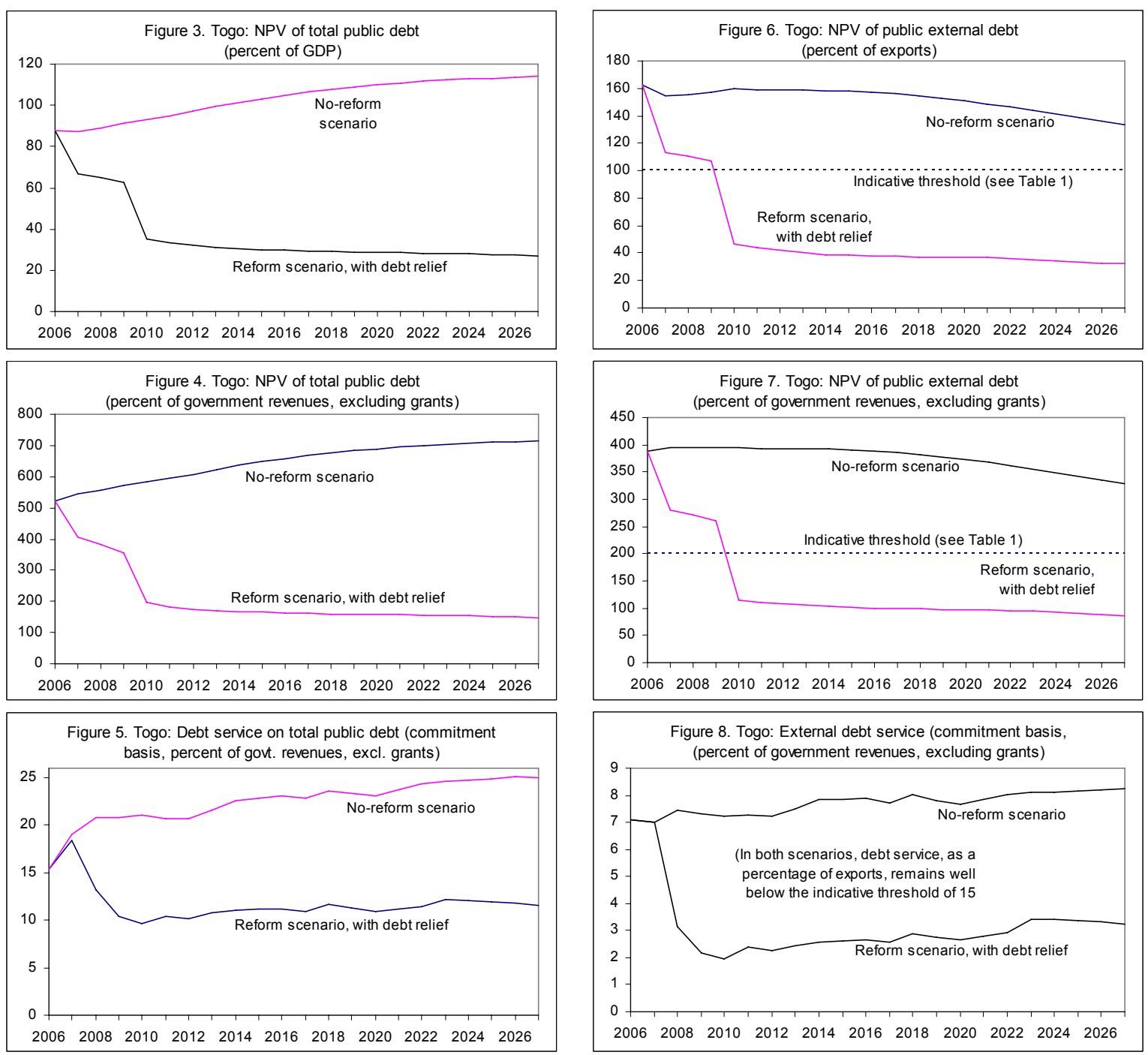

8. The reform scenario projects a steep decline in external and total public debt, owing to debt relief in the context of the Enhanced HIPC Initiative and MDRI, but also an improved macroeconomic and fiscal outlook in the longer run, owing to the implementation of a comprehensive reform program. In this scenario, the NPV of total public debt is projected to decline to 27 percent of GDP (148 percent of government revenues) by 2027, while the NPV of external debt falls to 16 percent of GDP, or 32 percent of exports and 85 percent of government revenues (Table 5). External debt service declines steeply owing to 
debt and arrears rescheduling and cancellation, including under HIPC/MDRI, between 2007 and 2010, and then increases modestly to around 3 percent of exports (Table 7). All debt indicators remain substantially below the applicable debt thresholds shown in Table 1.

9. Stress tests focus on debt sustainability and the robustness of the key debt indicators under the reform scenario after debt relief. All shocks are thus assumed to occur from 2011 on. Stress tests are summarized in Figures 9-11 and Table 6 (for total public debt), and in Figures 12-14 and Table 8 (for external debt).

10. Debt indicators remain below the applicable thresholds under most stress tests that simulate temporary shocks or policy reversals. Under most temporary shocks and reversals, debt increases in 2011-12 and gradually declines thereafter, reaching a sustainable level in the long term (see bound tests in Tables 6 and 8). External debt is particularly sensitive to stress test B4 (Table 8), which envisages a debt-financed shortfall in private transfers from abroad and FDI totaling about 20 percent of GDP spread over two years. In this case, the NPV of external debt rises above the relevant indicative threshold (Figure 12), but eventually reverts to a sustainable level. Under a severe output shock (bound test B1 of Table 6), with two successive years of real GDP growth set at 51/2 percentage points below trend, public debt as a share of GDP would increase and would not revert to a lower level.

11. Debt may revert to an unsustainable path (even after debt relief) in case of a permanent reversal in fiscal/economic reforms or a permanent economic shock without an adequate policy response. As shown in the alternative scenarios in Tables 6 and 8 (Figures 9-14), if key variables (such as growth, fiscal balances, external flows) revert to their historical averages, debt will generally increase over time and, in some cases, exceed indicative thresholds by 2027. Similarly, bound test B5 in Table 6 shows that a one-off increase in public debt by 30 percent would result in a gradually rising level of debt over the long term. This underlines that debt relief alone is insufficient to ensure debt sustainability if economic and fiscal reforms are not sustained. It also shows that permanent economic shocks will require fiscal adjustment beyond the policies assumed in the reform scenario to ensure debt sustainability. 
Figures 9-14. Stress Tests Under the Reform Scenario with Debt Relief.
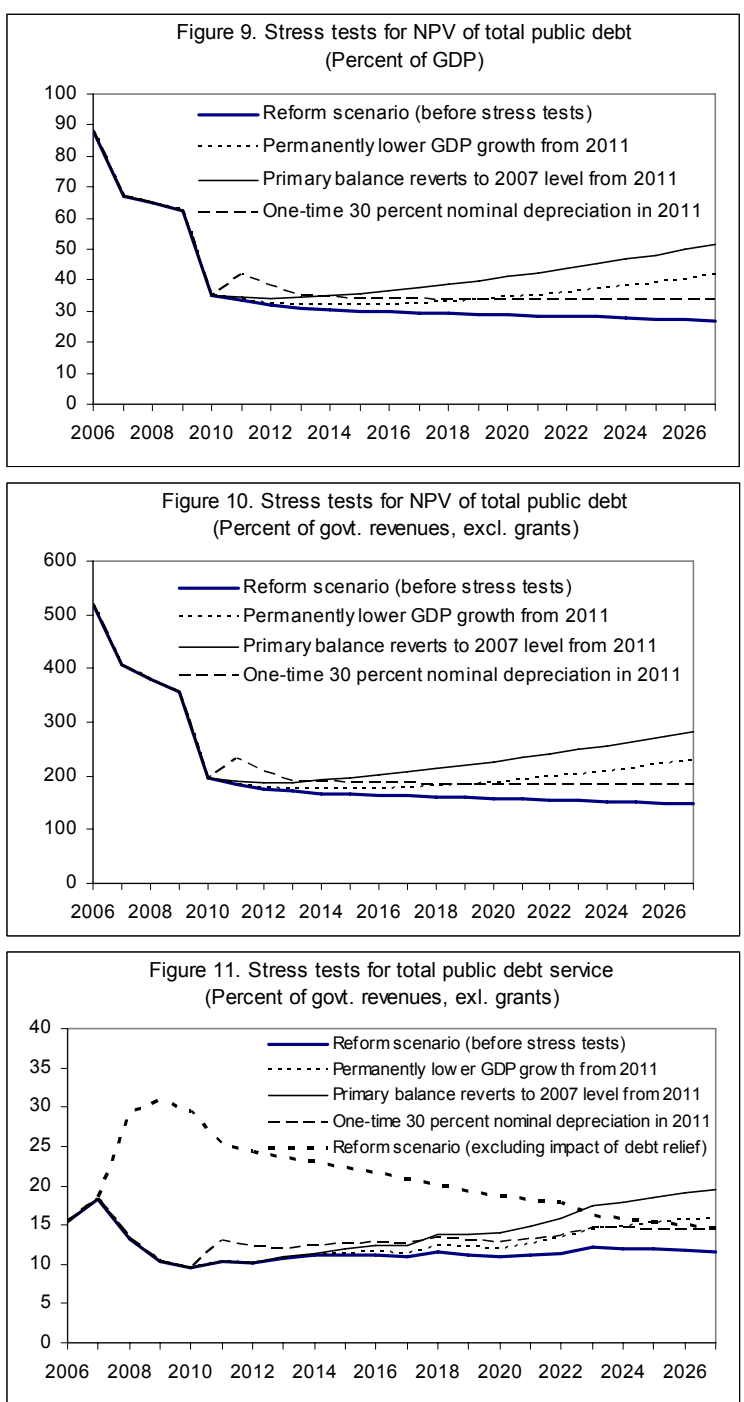
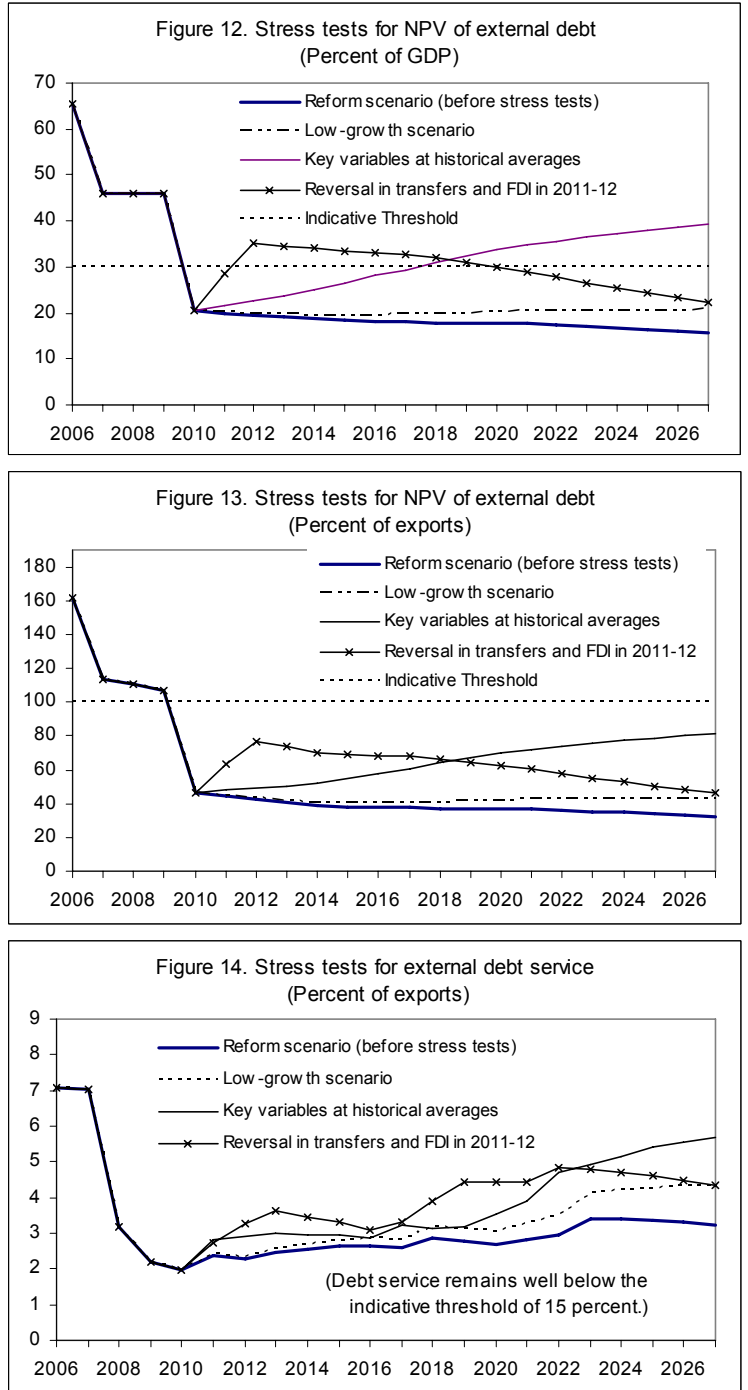

\section{CInternational Monetary Fund. Not for Redistribution}




\begin{tabular}{|c|c|c|c|c|c|c|c|c|c|c|c|c|c|}
\hline & \multirow{2}{*}{$\begin{array}{l}\text { Actual } \\
2006 \\
\end{array}$} & \multirow[b]{2}{*}{$\begin{array}{l}\text { Historical } \\
\text { Average }^{5}\end{array}$} & \multirow[b]{2}{*}{$\begin{array}{l}\text { Standard } \\
\text { Deviation }^{5}\end{array}$} & \multicolumn{10}{|c|}{ Projections } \\
\hline & & & & 2007 & 2008 & 2009 & 2010 & 2011 & 2012 & $\begin{array}{l}2007-12 \\
\text { Average }\end{array}$ & 2017 & 2027 & $\begin{array}{l}2013-27 \\
\text { Average }\end{array}$ \\
\hline $\begin{array}{l}\text { Public sector debt }{ }^{1} \\
\text { o/w foreign-currency denominated }\end{array}$ & $\begin{array}{r}102.9 \\
80.5\end{array}$ & & & $\begin{array}{r}103.3 \\
79.3\end{array}$ & $\begin{array}{r}104.9 \\
78.9\end{array}$ & $\begin{array}{r}107.0 \\
78.8\end{array}$ & $\begin{array}{r}109.0 \\
78.7\end{array}$ & $\begin{array}{r}110.8 \\
78.6\end{array}$ & $\begin{array}{r}113.1 \\
78.6\end{array}$ & & $\begin{array}{r}123.6 \\
78.6\end{array}$ & $\begin{array}{r}141.8 \\
80.5\end{array}$ & \\
\hline Change in public sector debt & 1.3 & & & 0.4 & 1.7 & 2.1 & 2.0 & 1.8 & 2.3 & & 2.0 & 1.7 & \\
\hline Identified debt-creating flows & -7.1 & & & -1.9 & 0.0 & 0.6 & 0.6 & 0.3 & 1.3 & & 1.0 & 0.7 & \\
\hline Primary deficit & 1.9 & -0.1 & 2.4 & 2.6 & 3.5 & 3.7 & 3.7 & 3.7 & 3.7 & 3.5 & 3.7 & 3.7 & 3.7 \\
\hline Revenue and grants & 18.3 & & & 17.5 & 17.0 & 17.0 & 17.0 & 17.0 & 17.0 & & 17.0 & 17.0 & \\
\hline of which: grants & 1.4 & & & 1.6 & 1.0 & 1.0 & 1.0 & 1.0 & 1.0 & & 1.0 & 1.0 & \\
\hline Primary (noninterest) expenditure & 20.2 & & & 20.2 & 20.5 & 20.7 & 20.7 & 20.7 & 20.7 & & 20.7 & 20.7 & \\
\hline Automatic debt dynamics & -8.9 & & & -4.5 & -3.5 & -3.1 & -3.2 & -3.4 & -2.5 & & -2.7 & -3.1 & \\
\hline Contribution from interest rate/growth differential & -3.1 & & & -3.2 & -2.4 & -2.4 & -2.4 & -2.6 & -2.6 & & -2.9 & -3.2 & \\
\hline of which: contribution from average real interest rate & -1.1 & & & -1.1 & -0.7 & -0.6 & -0.6 & -0.7 & -0.8 & & -0.8 & -0.9 & \\
\hline of which: contribution from real GDP growth & -2.0 & & & -2.1 & -1.7 & -1.8 & -1.8 & -1.8 & -1.9 & & -2.0 & -2.3 & \\
\hline Contribution from real exchange rate depreciation & -5.8 & & & -1.4 & -1.1 & -0.7 & -0.8 & -0.9 & 0.2 & & $\ldots$ & $\ldots$ & \\
\hline Other identified debt-creating flows & -0.1 & & & 0.0 & 0.0 & 0.0 & 0.0 & 0.0 & 0.0 & & 0.0 & 0.0 & \\
\hline Privatization receipts (negative) & -0.1 & & & 0.0 & 0.0 & 0.0 & 0.0 & 0.0 & 0.0 & & 0.0 & 0.0 & \\
\hline Recognition of implicit or contingent liabilities & 0.0 & & & 0.0 & 0.0 & 0.0 & 0.0 & 0.0 & 0.0 & & 0.0 & 0.0 & \\
\hline Debt relief (HIPC and other) & 0.0 & & & 0.0 & 0.0 & 0.0 & 0.0 & 0.0 & 0.0 & & 0.0 & 0.0 & \\
\hline Other (specify, e.g. bank recapitalization) & 0.0 & & & 0.0 & 0.0 & 0.0 & 0.0 & 0.0 & 0.0 & & 0.0 & 0.0 & \\
\hline Residual, including asset changes & 8.4 & & & 2.3 & 1.6 & 1.4 & 1.5 & 1.5 & 1.0 & & 1.0 & 1.0 & \\
\hline NPV of public sector debt & 87.9 & & & 87.1 & 88.9 & 91.0 & 93.2 & 94.9 & 97.0 & & 106.5 & 113.9 & \\
\hline o/w foreign-currency denominated & 65.6 & & & 63.1 & 62.9 & 62.9 & 62.9 & 62.7 & 62.5 & & 61.5 & 52.6 & \\
\hline o/w external & 65.6 & & & 63.1 & 62.9 & 62.9 & 62.9 & 62.7 & 62.5 & & 61.5 & 52.6 & \\
\hline NPV of contingent liabilities (not included in public sector debt) & 0.0 & & & 0.0 & 0.0 & 0.0 & 0.0 & 0.0 & 0.0 & & 0.0 & 0.0 & \\
\hline Gross financing need ${ }^{2}$ & 5.9 & & & 7.3 & 7.9 & 8.1 & 8.1 & 8.1 & 8.1 & & 8.4 & 8.7 & \\
\hline $\begin{array}{l}\text { NPV of public sector debt-to-revenue ratio (in percent) } \\
\text { o/w external }\end{array}$ & $\begin{array}{l}520.1 \\
387.9\end{array}$ & & & $\begin{array}{l}545.9 \\
395.5\end{array}$ & $\begin{array}{l}557.1 \\
394.0\end{array}$ & $\begin{array}{l}570.7 \\
394.1\end{array}$ & $\begin{array}{l}584.1 \\
394.3\end{array}$ & $\begin{array}{l}595.0 \\
393.3\end{array}$ & 608.3 & & $\begin{array}{l}667.5 \\
3854\end{array}$ & 713.9 & \\
\hline $\begin{array}{l}\text { o/w external } \\
\text { Debt service-to-I }\end{array}$ & $\begin{array}{r}387.9 \\
15.4\end{array}$ & & & $\begin{array}{r}395.5 \\
19.1\end{array}$ & $\begin{array}{r}394.0 \\
20.8\end{array}$ & $\begin{array}{r}394.1 \\
20.8\end{array}$ & $\begin{array}{r}394.3 \\
21.0\end{array}$ & $\begin{array}{r}393.3 \\
20.7\end{array}$ & $\begin{array}{r}392.0 \\
20.7\end{array}$ & & $\begin{array}{r}385.4 \\
22.8\end{array}$ & $\begin{array}{r}329.5 \\
25.0\end{array}$ & \\
\hline $\begin{array}{l}\text { Debt service-to-revenue ratio (in percent) } \\
\text { Primary deficit that stabilizes the debt-to-GDP ratio }\end{array}$ & 0.6 & & & 2.3 & 1.9 & $\begin{array}{r}2.0 \\
1.7\end{array}$ & 1.7 & $\begin{array}{r}20.1 \\
1.9\end{array}$ & $\begin{array}{r}2.1 \\
1.5\end{array}$ & & 1.7 & 2.1 & \\
\hline \multicolumn{14}{|l|}{ Key macroeconomic and fiscal assumptions } \\
\hline Real GDP growth (in percent) & 2.0 & 1.1 & 2.5 & 2.1 & 1.7 & 1.7 & 1.7 & 1.7 & 1.7 & 1.8 & 1.7 & 1.7 & 1.7 \\
\hline Average nominal interest rate on forex debt (in percent) & 1.1 & 1.8 & 0.6 & 1.0 & 1.3 & 1.2 & 1.2 & 1.1 & 1.1 & 1.2 & 1.1 & 1.0 & 1.0 \\
\hline Average real interest rate on domestic currency debt (in percent) & -1.9 & -0.9 & 6.9 & -1.2 & -0.5 & -0.2 & 0.0 & -0.3 & -0.3 & -0.4 & -0.3 & -0.2 & -0.3 \\
\hline Real exchange rate depreciation (in percent, + indicates depreciatior & -7.4 & -0.2 & 10.6 & -1.8 & 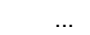 & & $\ldots$ & $\ldots$ & $\ldots$ & $\ldots$ & $\ldots$ & $\ldots$ & \\
\hline Inflation rate (GDP deflator, in percent) & 2.1 & 2.7 & 6.2 & 2.0 & 1.8 & 1.8 & 1.8 & 1.8 & 1.8 & 1.8 & 1.8 & 1.8 & 1.8 \\
\hline Growth of real primary spending (deflated by GDP deflator, in percer & 12.5 & 4.1 & 16.6 & 2.2 & 3.3 & 2.7 & 1.7 & 1.7 & 1.7 & 2.2 & 1.7 & 1.7 & 1.7 \\
\hline Grant element of new external borrowing (in percent) & 31.6 & 31.6 & 0.0 & 31.6 & 31.6 & 31.6 & 31.6 & 31.6 & 31.6 & 31.6 & 31.6 & 31.6 & $\ldots$ \\
\hline
\end{tabular}

Sources: Togolese authorities; and Fund staff estimates and projections.

${ }^{1}$ General government debt.

${ }^{2}$ Gross financing need is defined as the primary deficit plus debt service plus the stock of short-term debt at the end of the last period.

${ }^{3}$ Revenues excluding grants.
${ }^{4}$ Debt sevice is defined as the st

${ }^{4}$ Debt service is defined as the sum of interest and amortization of medium and long-term debt.

${ }^{5}$ Historical averages and standard deviations are generally derived over the past 10 years, subject to data availability 
Table 4. Togo: External Debt Sustainability Framework, No-Reform Scenario, 2007-2027 ${ }^{1}$

(In percent of GDP, unless otherwise indicated)

\begin{tabular}{|c|c|c|c|c|c|c|c|c|c|c|c|c|c|}
\hline & \multirow{2}{*}{$\begin{array}{r}\text { Actual } \\
2006 \\
\end{array}$} & \multirow[b]{2}{*}{$\begin{array}{l}\text { Historical } \\
\text { Average }^{6}\end{array}$} & \multirow[b]{2}{*}{$\begin{array}{l}\text { Standard } \\
\text { Deviation }^{6}\end{array}$} & \multicolumn{7}{|c|}{ Projections } & \multirow[b]{2}{*}{2017} & \multirow[b]{2}{*}{2027} & \multirow[b]{2}{*}{$\begin{array}{l}2013-27 \\
\text { Average }\end{array}$} \\
\hline & & & & 2007 & 2008 & 2009 & 2010 & 2011 & 2012 & $\begin{array}{l}2007-12 \\
\text { Average }\end{array}$ & & & \\
\hline External debt (nominal) ${ }^{1}$ & 80.5 & & & 79.3 & 78.9 & 78.8 & 78.7 & 78.6 & 78.6 & & 78.6 & 80.2 & \\
\hline o/w public and publicly guaranteed (PPG) & 80.5 & & & 79.3 & 78.9 & 78.8 & 78.7 & 78.6 & 78.6 & & 78.6 & 80.2 & \\
\hline Change in external debt & -11.8 & & & -1.3 & -0.4 & -0.1 & -0.1 & -0.1 & -0.1 & & 0.1 & 0.2 & \\
\hline Identified net debt-creating flows & -5.7 & & & 2.4 & 1.9 & 2.4 & 3.0 & 3.4 & 3.4 & & 3.4 & 3.4 & \\
\hline Non-interest current account deficit & 5.2 & 4.7 & 2.5 & 5.7 & 5.2 & 5.8 & 6.4 & 6.8 & 6.8 & & 6.8 & 6.8 & 6.8 \\
\hline Deficit in balance of goods and services & 19.6 & & & 21.0 & 20.8 & 21.0 & 21.3 & 21.3 & 21.3 & & 21.3 & 21.3 & \\
\hline Exports & 40.5 & & & 40.9 & 40.4 & 39.9 & 39.4 & 39.4 & 39.4 & & 39.4 & 39.4 & \\
\hline Imports & 60.1 & & & 62.0 & 61.2 & 60.9 & 60.7 & 60.7 & 60.7 & & 60.7 & 60.7 & \\
\hline Net current transfers (negative $=$ inflow) & -14.7 & -10.2 & 2.7 & -16.0 & -15.6 & -15.2 & -14.8 & -14.4 & -14.4 & & -14.4 & -14.4 & -14.4 \\
\hline Other current account flows (negative $=$ net inflow) & 0.3 & & & 0.7 & 0.0 & 0.0 & 0.0 & 0.0 & 0.0 & & 0.0 & 0.0 & \\
\hline Net FDI (negative = inflow) & -3.4 & -2.6 & 1.0 & -2.5 & -3.0 & -3.0 & -3.0 & -3.0 & -3.0 & & -3.0 & -3.0 & -3.0 \\
\hline Endogenous debt dynamics ${ }^{2}$ & -7.4 & & & -0.8 & -0.3 & -0.3 & -0.4 & -0.4 & -0.5 & & -0.5 & -0.4 & \\
\hline Contribution from nominal interest rate & 0.9 & & & 0.8 & 1.0 & 0.9 & 0.9 & 0.9 & 0.8 & & 0.8 & 0.9 & \\
\hline Contribution from real GDP growth & -1.7 & & & -1.6 & -1.3 & -1.3 & -1.3 & -1.3 & -1.3 & & -1.3 & -1.3 & \\
\hline Contribution from price and exchange rate changes & -6.6 & & & $\ldots$ & $\ldots$ & $\ldots$ & $\ldots$ & $\ldots$ & $\ldots$ & & $\ldots$ & $\ldots$ & \\
\hline Residual $(3-4)^{3}$ & -6.1 & & & -3.6 & -2.2 & -2.5 & -3.1 & -3.5 & -3.4 & & -3.3 & -3.2 & \\
\hline o/w exceptional financing & 0.0 & & & 0.0 & 0.0 & 0.0 & 0.0 & 0.0 & 0.0 & & 0.0 & 0.0 & \\
\hline NPV of external debt ${ }^{4}$ & 65.6 & & & 63.1 & 62.9 & 62.9 & 62.9 & 62.7 & 62.5 & & 61.5 & 52.6 & \\
\hline In percent of exports & 162.1 & & & 154.1 & 155.4 & 157.4 & 159.5 & 159.1 & 158.6 & & 155.9 & 133.3 & \\
\hline NPV of PPG external debt & 65.6 & & & 63.1 & 62.9 & 62.9 & 62.9 & 62.7 & 62.5 & & 61.5 & 52.6 & \\
\hline In percent of exports & 162.1 & & & 154.1 & 155.4 & 157.4 & 159.5 & 159.1 & 158.6 & & 155.9 & 133.3 & \\
\hline Debt service-to-exports ratio (in percent) & 7.1 & & & 7.0 & 7.5 & 7.3 & 7.2 & 7.3 & 7.2 & & 7.7 & 8.3 & \\
\hline PPG debt service-to-exports ratio (in percent) & 7.1 & & & 7.0 & 7.5 & 7.3 & 7.2 & 7.3 & 7.2 & & 7.7 & 8.3 & \\
\hline Total gross financing need (billions of U.S. dollars) & 0.1 & & & 0.3 & 0.1 & 0.2 & 0.3 & -0.2 & -0.2 & & -0.3 & -0.4 & \\
\hline Non-interest current account deficit that stabilizes debt ratio & 17.0 & & & 6.9 & 5.5 & 5.8 & 6.5 & 6.9 & 6.9 & & 6.8 & 6.6 & \\
\hline \multicolumn{14}{|l|}{ Key macroeconomic assumptions } \\
\hline Real GDP growth (in percent) & 2.0 & 1.1 & 2.5 & 2.1 & 1.7 & 1.7 & 1.7 & 1.7 & 1.7 & 1.8 & 1.7 & 1.7 & 1.7 \\
\hline GDP deflator in US dollar terms (change in percent) & 7.7 & 3.8 & 11.4 & 5.2 & 3.8 & 3.1 & 3.0 & 3.2 & 2.4 & 3.4 & 1.8 & 1.8 & 1.8 \\
\hline Effective interest rate (percent) $)^{5}$ & 1.0 & 1.0 & 0.8 & 1.0 & 1.3 & 1.3 & 1.2 & 1.1 & 1.1 & 1.2 & 1.1 & 1.1 & 1.1 \\
\hline Growth of exports of G\&S (US dollar terms, in percent) & 5.1 & 7.6 & 14.0 & 8.7 & 4.3 & 3.5 & 3.4 & 4.9 & 4.2 & 4.8 & 3.5 & 3.5 & 3.5 \\
\hline Growth of imports of G\&S (US dollar terms, in percent) & 9.9 & 8.0 & 11.3 & 10.8 & 4.3 & 4.3 & 4.3 & 4.9 & 4.2 & 5.5 & 3.5 & 3.5 & 3.5 \\
\hline Grant element of new public sector borrowing (in percent) & $\ldots$ & $\ldots$ & $\ldots$ & 35.6 & 35.6 & 35.6 & 35.6 & 35.6 & 35.6 & 35.6 & 35.6 & 35.6 & 35.6 \\
\hline \multicolumn{14}{|l|}{ Memorandym item: } \\
\hline Nominal GDP (billions of US dollars) & 2.2 & & & 2.4 & 2.5 & 2.6 & 2.8 & 2.9 & 3.0 & & 3.6 & 5.1 & \\
\hline
\end{tabular}

${ }^{1}$ Public sector external debt.

${ }^{2}$ Derived as $[r-g-r(1+g)] /(1+g+r+g r)$ times previous period debt ratio, with $r=$ nominal interest rate; $g=$ real GDP growth rate, and $r=$ growth rate of GDP deflator in U.S. dollar terms.

${ }^{3}$ Includes exceptional financing (i.e., changes in arrears and debt relief); changes in gross foreign assets; and valuation adjustments. For projections also includes contribution from price and exchange rate changes.

${ }^{4}$ Assumes that NPV of private sector debt is equivalent to its face value.

${ }^{5}$ Current-year interest payments devided by previous period debt stock.

${ }^{6}$ Historical averages and standard deviations are generally derived over the past 10 years, subject to data availability. 


\begin{tabular}{|c|c|c|c|c|c|c|c|c|c|c|c|c|c|}
\hline & \multirow{2}{*}{$\begin{array}{l}\text { Actual } \\
2006 \\
\end{array}$} & \multirow[b]{2}{*}{$\begin{array}{l}\text { Historical } \\
\text { Average }^{5} \\
\end{array}$} & \multirow[b]{2}{*}{$\begin{array}{l}\text { Standard } \\
\text { Deviation }^{5}\end{array}$} & \multicolumn{10}{|c|}{ Projections } \\
\hline & & & & 2007 & 2008 & 2009 & 2010 & 2011 & 2012 & $\begin{array}{l}2007-12 \\
\text { Average }\end{array}$ & 2017 & 2027 & $\begin{array}{l}\text { 2013-27 } \\
\text { Average } \\
\end{array}$ \\
\hline $\begin{array}{l}\text { Public sector debt }{ }^{1} \\
\text { of which: foreign-currency denominated }\end{array}$ & $\begin{array}{r}102.9 \\
80.5\end{array}$ & & & $\begin{array}{l}93.2 \\
72.3\end{array}$ & $\begin{array}{l}87.0 \\
68.2\end{array}$ & $\begin{array}{l}81.7 \\
65.0\end{array}$ & $\begin{array}{l}53.5 \\
38.8\end{array}$ & $\begin{array}{l}50.7 \\
37.3\end{array}$ & $\begin{array}{l}48.4 \\
36.0\end{array}$ & & $\begin{array}{l}40.9 \\
29.6\end{array}$ & $\begin{array}{l}31.3 \\
19.8\end{array}$ & \\
\hline Change in public sector debt & 1.3 & & & -9.7 & -6.2 & -5.3 & -28.2 & -2.8 & -2.3 & & -1.2 & -0.7 & \\
\hline Identified debt-creating flows & -7.1 & & & -3.7 & -3.5 & -3.5 & -3.6 & -1.9 & -1.3 & & -0.7 & -0.3 & \\
\hline Primary deficit & 1.9 & -0.1 & 2.4 & 1.6 & 1.3 & 1.0 & 0.7 & 0.6 & 0.6 & 1.0 & 0.6 & 0.6 & 0.6 \\
\hline Revenue and grants & 18.3 & & & 19.0 & 20.2 & 21.3 & 22.3 & 22.4 & 22.4 & & 22.4 & 22.4 & \\
\hline of which: grants & 1.4 & & & 2.6 & 3.2 & 3.7 & 4.3 & 4.2 & 4.2 & & 4.2 & 4.2 & \\
\hline Primary (noninterest) expenditure & 20.2 & & & 20.7 & 21.5 & 22.3 & 23.0 & 23.0 & 23.0 & & 23.0 & 23.0 & \\
\hline Automatic debt dynamics & -8.9 & & & -5.3 & -4.8 & -4.5 & -4.3 & -2.5 & -1.9 & & -1.3 & -0.9 & \\
\hline Contribution from interest rate/growth differential & -2.3 & & & -3.2 & -3.0 & -3.1 & -2.9 & -1.6 & -1.5 & & -1.0 & -0.7 & \\
\hline of which: contribution from average real interest rate & -0.3 & & & -0.3 & 0.2 & 0.2 & 0.2 & 0.5 & 0.4 & & 0.5 & 0.4 & \\
\hline of which: contribution from real GDP growth & -2.0 & & & -2.9 & -3.2 & -3.3 & -3.1 & -2.1 & -2.0 & & -1.4 & -1.1 & \\
\hline Contribution from real exchange rate depreciation & -6.6 & & & -2.1 & -1.8 & -1.4 & -1.4 & -0.9 & -0.4 & & $\ldots$ & $\ldots$ & \\
\hline Other identified debt-creating flows & -0.1 & & & 0.0 & 0.0 & 0.0 & 0.0 & 0.0 & 0.0 & & 0.0 & 0.0 & \\
\hline Privatization receipts (negative) & -0.1 & & & 0.0 & 0.0 & 0.0 & 0.0 & 0.0 & 0.0 & & 0.0 & 0.0 & \\
\hline Recognition of implicit or contingent liabilities & 0.0 & & & 0.0 & 0.0 & 0.0 & 0.0 & 0.0 & 0.0 & & 0.0 & 0.0 & \\
\hline Debt relief (HIPC and other) & 0.0 & & & 0.0 & 0.0 & 0.0 & 0.0 & 0.0 & 0.0 & & 0.0 & 0.0 & \\
\hline Other (specify, e.g. bank recapitalization) & 0.0 & & & 0.0 & 0.0 & 0.0 & 0.0 & 0.0 & 0.0 & & 0.0 & 0.0 & \\
\hline Residual, including asset changes & 8.4 & & & -6.0 & -2.7 & -1.8 & -24.6 & -0.9 & -1.1 & & -0.5 & -0.4 & \\
\hline NPV of public sector debt & 87.9 & & & 66.9 & 64.8 & 62.6 & 35.3 & 33.4 & 32.0 & & 29.5 & 27.0 & \\
\hline of which: foreign-currency denominated & 65.6 & & & 46.0 & 46.0 & 45.8 & 20.5 & 19.9 & 19.5 & & 18.1 & 15.5 & \\
\hline of which: external & 65.6 & & & 46.0 & 46.0 & 45.8 & 20.5 & 19.9 & 19.5 & & 18.1 & 15.5 & \\
\hline NPV of contingent liabilities (not included in public sector debt) & 0.0 & & & 0.0 & 0.0 & 0.0 & 0.0 & 0.0 & 0.0 & & 0.0 & 0.0 & \\
\hline Gross financing need ${ }^{2}$ & 5.9 & & & 7.2 & 6.7 & 6.5 & 6.7 & 6.7 & 6.7 & & 6.8 & 6.9 & \\
\hline NPV of public sector debt-to-revenue ratio (in percent) ${ }^{3}$ & 520.1 & & & 406.7 & 381.1 & 355.4 & 196.0 & 183.2 & 175.6 & & 162.1 & 148.3 & \\
\hline of which: external & 387.9 & & & 279.7 & 270.5 & 260.4 & 114.0 & 109.6 & 107.2 & & 99.7 & 85.3 & \\
\hline Debt service-to-revenue ratio (in percent) ${ }^{3,4}$ & 15.4 & & & 18.3 & 13.2 & 10.4 & 9.6 & 10.4 & 10.2 & & 10.9 & 11.6 & \\
\hline Primary deficit that stabilizes the debt-to-GDP ratio & 0.6 & & & 11.3 & 7.5 & 6.3 & 28.9 & 3.4 & 2.9 & & 1.8 & 1.3 & \\
\hline \multicolumn{14}{|l|}{ Key macroeconomic and fiscal assumptions } \\
\hline Real GDP growth (percent) & 2.0 & 1.1 & 2.5 & 2.9 & 3.5 & 4.0 & 4.0 & 4.0 & 4.0 & 3.7 & 3.5 & 3.5 & 3.6 \\
\hline Average nominal interest rate on forex debt (percent) & 1.1 & 1.8 & 0.6 & 1.0 & 0.5 & 0.5 & 0.4 & 0.7 & 0.6 & 0.6 & 0.7 & 1.3 & 0.9 \\
\hline Average real interest rate on domestic currency debt (percent) & -1.9 & -0.9 & 6.9 & -1.2 & 2.7 & 3.0 & 3.4 & 3.9 & 4.3 & 2.7 & 4.7 & 3.0 & 4.1 \\
\hline Real exchange rate depreciation (percent, "+" indicates depreciation) & -8.3 & -1.2 & 10.5 & -2.7 & $\ldots$ & $\ldots$ & $\ldots$ & $\ldots$ & $\ldots$ & $\ldots$ & $\ldots$ & $\ldots$ & $\ldots$ \\
\hline Inflation rate (GDP deflator, percent) & 2.1 & 2.7 & 6.2 & 2.0 & 2.0 & 2.0 & 2.0 & 2.0 & 2.0 & 2.0 & 2.0 & 2.0 & 2.0 \\
\hline Growth of real primary spending (deflated by GDP deflator, percent) & 12.5 & 4.1 & 16.6 & 5.5 & 7.6 & 7.9 & 7.3 & 4.0 & 4.0 & 6.0 & 3.5 & 3.5 & 3.6 \\
\hline Grant element of new external borrowing (percent) & 31.6 & 31.6 & 0.0 & 31.6 & 31.6 & 31.6 & 31.6 & 31.6 & 31.6 & 31.6 & 31.6 & 31.6 & ... \\
\hline
\end{tabular}

Sources: Togolese authorities; and Fund staff estimates and projections.

${ }^{1}$ General government debt.

${ }^{2}$ Gross financing need is defined as the primary deficit plus debt service plus the stock of short-term debt at the end of the last period.

${ }^{3}$ Revenues excluding grants.

${ }^{4}$ Debt service is defined as the sum of interest and amortization of medium and long-term debt.

${ }^{5}$ Historical averages and standard deviations are generally derived over the past 10 years, subject to data availability. 
Table 6. Togo: Sensitivity Analysis for Key Indicators of Public Debt (Reform Scenario), 2007-27

Projections

$\begin{array}{llllllll}2007 & 2008 & 2009 & 2010 & 2011 & 2012 & 2017 & 2027\end{array}$

NPV of Debt-to-GDP Ratio

Reform Scenario

$\begin{array}{llllllll}67 & 65 & 63 & 35 & 33 & 32 & 30 & 27\end{array}$

\section{A. Alternative scenarios}

A1. Real GDP growth and primary balance are at historical averages

A2. Primary balance reverts to 2007 level from 2011

A3. Permanently lower GDP growth ${ }^{1}$

\section{B. Bound tests}

B1. Real GDP growth at historical average minus one standard deviations in 2011-12

B2. Primary balance at historical average minus one standard deviations in 2011-12

B3. Combination of B1-B2 using one-half standard deviation shocks

B4. One-time 30 percent nominal depreciation in 2011

B5. 10 percent of GDP increase in other debt-creating flows in 2011

NPV of Debt-to-Revenue Ratio ${ }^{2}$

\section{Reform Scenario}

\section{A. Alternative scenarios}

A1. Real GDP growth and primary balance are at historical averages

A2. Primary balance reverts to 2007 level from 2011

A3. Permanently lower GDP growth'

\section{B. Bound tests}

B1. Real GDP growth at historical average minus one standard deviations in 2011-12

B2. Primary balance at historical average minus one standard deviations in 2011-12

B3. Combination of B1-B2 using one-half standard deviation shocks

B4. One-time 30 percent nominal depreciation in 2011

B5. 10 percent of GDP increase in other debt-creating flows in 2011

$\begin{array}{llllllll}\ldots & \ldots & \ldots & 35 & 34 & 34 & 38 & 53 \\ \ldots & \ldots & \ldots & 35 & 34 & 34 & 38 & 51 \\ \ldots & \ldots & \ldots & 35 & 34 & 33 & 33 & 42\end{array}$

$\begin{array}{llllllll}\ldots & \ldots & \ldots & 35 & 36 & 37 & 36 & 37\end{array}$

$\begin{array}{llllllll}\ldots & \ldots & \ldots & 35 & 35 & 35 & 34 & 33\end{array}$

$\begin{array}{llllllll}\ldots & \ldots & \ldots & 35 & 35 & 36 & 35 & 35\end{array}$

$\begin{array}{llllllll}\ldots & \ldots & \ldots & 35 & 42 & 38 & 34 & 33\end{array}$

$\begin{array}{llllllll}\ldots & \ldots & \ldots & 35 & 43 & 42 & 42 & 46\end{array}$

Debt Service-to-Revenue Ratio ${ }^{2}$

Reform Scenario

$16 \quad 11$

11

98

8

89

9

\section{A. Alternative scenarios}

A1. Real GDP growth and primary balance are at historical averages

A2. Primary balance reverts to 2007 level from 2011

A3. Permanently lower GDP growth ${ }^{1}$

$\begin{array}{llllllll}\ldots & \ldots & \ldots & 10 & 10 & 10 & 13 & 20 \\ \cdots & \cdots & \ldots & 10 & 10 & 10 & 12 & 19 \\ & \cdots & \cdots & 10 & 10 & 10 & 11 & 16\end{array}$

\section{B. Bound tests}

B1. Real GDP growth at historical average minus one standard deviations in 2011-12

B2. Primary balance at historical average minus one standard deviations in 2011-12

B3. Combination of B1-B2 using one-half standard deviation shocks

B4. One-time 30 percent nominal depreciation in 2011

B5. 10 percent of GDP increase in other debt-creating flows in 2011

$\begin{array}{llllllll}\ldots & \ldots & \ldots & 10 & 10 & 10 & 13 & 15 \\ \ldots & \ldots & \ldots & 10 & 10 & 10 & 12 & 14 \\ \ldots & \ldots & \ldots & 10 & 10 & 10 & 13 & 15 \\ \ldots & \ldots & \ldots & 10 & 13 & 12 & 13 & 14 \\ \ldots & \ldots & \ldots & 10 & 10 & 11 & 15 & 19\end{array}$

Sources: Togolese authorities; and Fund staff estimates and projections.

${ }^{1}$ Assumes that real GDP growth is is lowered by one percentage point over the length of the projection period.

${ }^{2}$ Revenues are defined excluding grants. 
Table 7. Togo: External Debt Sustainability Framework, Reform Scenario, 2006-27

(Percent of GDP, unless otherwise indicated)

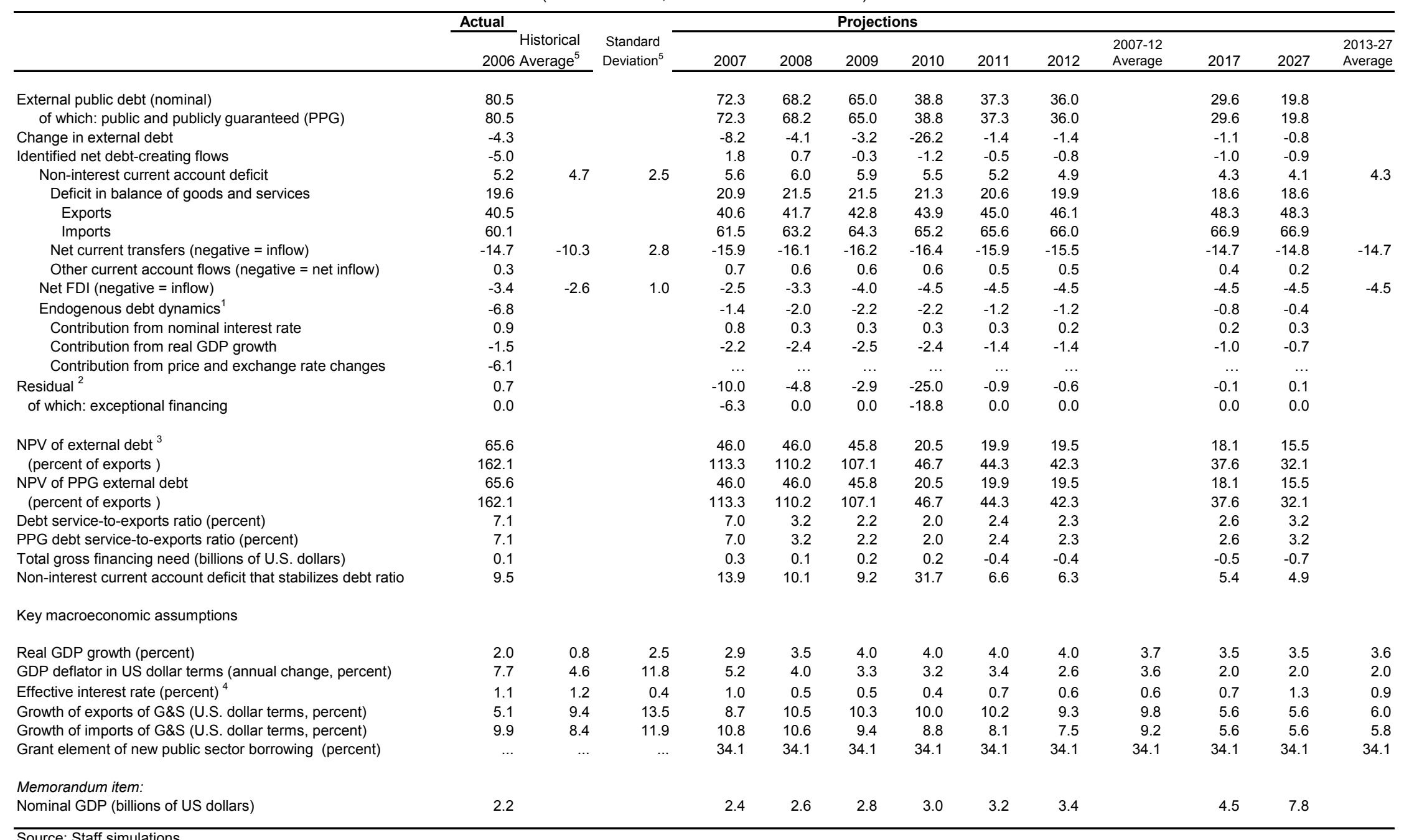

${ }^{1}$ Derived as $[r-g-r(1+g)] /(1+g+r+g r)$ times previous period debt ratio, with $r=$ nominal interest rate; $g=$ real GDP growth rate, and $r=$ growth rate of GDP deflator in U.S. dollar terms

${ }_{2}^{2}$ Includes exceptional financing (i.e., changes in arrears and debt relief), changes in gross foreign assets, valuation adjustments, and (for projections only) the contribution from price and exchange rate changes.

${ }^{3}$ Assumes that NPV of private sector debt is equivalent to its face value.

${ }^{4}$ Current-year interest payments divided by previous period debt stock.

${ }^{5}$ Historical averages and standard deviations are generally derived over the past 10 years, subject to data availability. 
Table 8. Togo: Sensitivity Analyses for Key Indicators of Public and Publicly Guaranteed External Debt (Reform Scenario), 2007-27 (Percent)

\section{NPV of debt-to-GDP ratio}

Reform scenario

\section{A. Alternative Scenarios}

A1. Key variables at their historical averages in $2008-27^{1}$

A2. New public sector loans on less favorable terms in $2008-27^{2}$

\section{B. Bound Tests}

B1. Real GDP growth reduced by 1 percentage point relative to baseline from 2011

B2. Export value growth at historical average minus one standard deviation in 2011-12 ${ }^{3}$

B3. U.S. dollar GDP deflator at historical average minus one standard deviation in 2011-12

B4. Net non-debt-creating flows at historical average minus one standard deviation in 2011-12 ${ }^{4}$

B5. Combination of B1-B4 using one-half size shocks

B6. One-time 30 percent nominal depreciation relative to the baseline in $2011^{5}$

\section{NPV of debt-to-exports ratio}

\section{Reform scenario}

\section{A. Alternative Scenarios}

A1. Key variables at their historical averages in $2008-27^{1}$

A2. New public sector loans on less favorable terms in $2008-27^{2}$

\section{B. Bound Tests}

B1. Real GDP growth reduced by 1 percentage point relative to baseline from 2011

B2. Export value growth at historical average minus one standard deviation in 2011-12 ${ }^{3}$

B3. U.S. dollar GDP deflator at historical average minus one standard deviation in 2011-12

B4. Net non-debt-creating flows at historical average minus one standard deviation in 2011-12 ${ }^{4}$

B5. Combination of B1-B4 using one-half size shocks

B6. One-time 30 percent nominal depreciation relative to the baseline in $2011^{5}$

\section{Debt service-to-exports ratio}

\section{Reform scenario}

\section{A. Alternative Scenarios}

A1. Key variables at their historical averages in $2008-27^{1}$

A2. New public sector loans on less favorable terms in $2008-27^{2}$

\section{B. Bound Tests}

B1. Real GDP growth reduced by 1 percentage point relative to baseline from 2011

B2. Export value growth at historical average minus one standard deviation in 2011-12 ${ }^{3}$

B3. U.S. dollar GDP deflator at historical average minus one standard deviation in 2011-12

B4. Net non-debt-creating flows at historical average minus one standard deviation in 2011-12 ${ }^{4}$

B5. Combination of B1-B4 using one-half size shocks

B6. One-time 30 percent nominal depreciation relative to the baseline in $2011^{5}$

Memorandum item:

Grant element assumed on residual financing (i.e., financing required above baseline) ${ }^{6}$

$\begin{array}{llllllll}46 & 46 & 46 & 21 & 20 & 20 & 18 & 16 \\ & & & & & & & \\ \ldots & \ldots & \ldots & 21 & 22 & 23 & 29 & 39 \\ \ldots & \ldots & \ldots & 23 & 22 & 22 & 23 & 23\end{array}$

$\begin{array}{llllllll}\ldots & \ldots & \ldots & 21 & 20 & 20 & 20 & 21 \\ \ldots & \ldots & \ldots & 21 & 21 & 20 & 19 & 16 \\ \ldots & \ldots & \ldots & 21 & 23 & 25 & 24 & 20 \\ \ldots & \ldots & \ldots & 21 & 29 & 35 & 33 & 22 \\ \ldots & \ldots & \ldots & 22 & 26 & 31 & 29 & 24 \\ \ldots & \ldots & \ldots & 21 & 28 & 26 & 23 & 22\end{array}$

$\begin{array}{llllllll}\ldots & \ldots & \ldots & 47 & 45 & 43 & 41 & 43 \\ \ldots & \ldots & \ldots & 49 & 54 & 61 & 54 & 46 \\ \ldots & \ldots & \ldots & 49 & 46 & 44 & 39 & 33 \\ \ldots & \ldots & \ldots & 49 & 63 & 77 & 68 & 46 \\ \ldots & \ldots & \ldots & 50 & 60 & 70 & 63 & 52 \\ \ldots & \ldots & \ldots & 49 & 75 & 72 & 63 & 44\end{array}$

Source: Staff projections and simulations.

${ }^{1}$ Variables include real GDP growth, growth of GDP deflator (in U.S. dollar terms), non-interest current account in percent of GDP, and non-debt creating flor

${ }^{2}$ Assumes that the interest rate on new borrowing is 2 percentage points higher than in the baseline, while grace and maturity periods are the same as in the

${ }^{3}$ Exports values are assumed to remain permanently at the lower level, but the current account as a share of GDP is assumed to return to its baseline level $;$ (implicitly assuming an offsetting adjustment in import levels).

${ }^{4}$ Includes official and private transfers and FDI.

${ }^{5}$ Depreciation is defined as percentage decline in dollar/local currency rate, such that it never exceeds 100 percent.

${ }^{6}$ Applies to all stress scenarios except for A2 (less favorable financing) in which the terms on all new financing are as specified in footnote 2.

\section{CInternational Monetary Fund. Not for Redistribution}




\section{SUPPLEMENT II \\ I-RELATIONS WITH THE FUND}

(As of May 7, 2007)

I. Membership Status: Joined August 1, 1962; Article VIII

II. General Resources Account:

Quota

Fund holdings of currency

Reserve position in the Fund

III. SDR Department:

Net cumulative allocation

Holdings

IV. Outstanding Purchases and Loans:

Poverty Reduction and Growth Facility

(PRGF) arrangements
SDR million

73.40

73.07

0.33

SDR million

10.98

0.02

SDR million

3.26
Percent of quota

100.00

99.55

0.45

Percent of allocation

100.00

0.19

Percent of quota

4.44

V. Financial Arrangements:

\begin{tabular}{|c|c|c|c|c|}
\hline Type & $\begin{array}{l}\text { Approval } \\
\text { Date }\end{array}$ & $\begin{array}{l}\text { Expiration } \\
\text { Date }\end{array}$ & $\begin{array}{l}\text { Amount Approved } \\
\text { (SDR million) }\end{array}$ & $\begin{array}{l}\text { Amount Drawn } \\
\text { (SDR million) }\end{array}$ \\
\hline PRGF & 09/16/94 & $06 / 29 / 98$ & 65.16 & 54.30 \\
\hline PRGF & $05 / 31 / 89$ & 05/19/93 & 46.08 & 38.40 \\
\hline $\begin{array}{l}\text { Structural } \\
\text { Adjustment } \\
\text { Facility (SAF) }\end{array}$ & $03 / 16 / 88$ & 05/30/89 & 26.88 & 7.68 \\
\hline
\end{tabular}

VI. Projected Payments to the Fund ${ }^{1}$

(SDR million; based on existing use of resources and present holdings of SDRs)

\begin{tabular}{lrrrrr} 
& \multicolumn{5}{c}{ Forthcoming } \\
\cline { 5 - 6 } & 2007 & 2008 & 2009 & 2010 & 2011 \\
Principal & 2.17 & 1.09 & 0.00 & 0.00 & 0.00 \\
Charges/interest & 0.36 & 0.46 & 0.46 & 0.46 & 0.46 \\
Total & 2.53 & 1.55 & 0.46 & 0.46 & 0.46
\end{tabular}

\footnotetext{
${ }^{1}$ When a member has overdue financial obligations outstanding for more than three months, the amount of such arrears will be shown in this section.
} 


\section{Exchange Arrangement}

Togo is a member of the West African Economic and Monetary Union (WAEMU) and has no separate legal tender. The exchange system, common to all WAEMU countries, is free of restrictions on the making of payments and transfers for current international transactions. The union's common currency, the CFA franc, is pegged to the euro at a rate of CFAF $655.957=$ EUR 1, consistent with the official conversions rate of the French franc to the euro and the previous fixed rate of the CFA franc to the French franc of CFAF $100=$ F 1 . On April 28, 2006, the rate of the CFA franc in terms of SDR was CFAF 769.68=SDR 1.0. Effective January 1, 2007, the exchange arrangement of the WAEMU countries has been reclassified to the category of conventional pegged arrangement from the category of exchange arrangement with no separate legal tender. The new classification is based on the behavior of the common currency, whereas the previous classification was based on the lack of a separate legal tender. The new classification thus only reflects a definitional change, and is not based on a judgment that there has been a substantive change in the exchange regime or other policies of the currency union or its members

\section{Safeguards Assessments}

The Central Bank of West African States (BCEAO) is the common central bank of the countries of the West African Economic and Monetary Union. The most recent safeguards assessment of the BCEAO was completed on November 4, 2005. The assessment indicates that progress has been made in strengthening the bank's safeguards framework since the 2002 safeguards assessment.

The BCEAO now publishes a full set of audited financial statements and improvements have been made to move financial reporting closer to International Financial Reporting Standards (IFRS). Furthermore, an internal audit charter has been put in place, mechanisms for improving risk management and risk prevention have been established and follow-up on internal and external audit recommendations has been strengthened.

The new assessment identified a number of areas where further steps would help solidify the progress made. The main recommendations relate to improvements in the external audit process (including the adoption of a formal rotation policy), further enhancement of the transparency of the financial statements by fully adopting IFRS, and further strengthening of the effectiveness of the internal audit function. The status report of the implementation of recommendations, received from the bank in March 2007, indicates that some progress was achieved.

\section{Article IV Consultation}

Togo is on the standard 12-month Article IV consultation cycle. The Executive Board completed the 2005 Article IV consultation on May 8, 2006. 


\section{Technical Assistance}

\section{Department Type of Assistance Time of Delivery Purpose}

$\begin{array}{llll}\text { FAD } & \text { Staff } & \text { December 2007 } & \text { Tax administration } \\ \text { MFD } & \text { Staff } & \text { March 2006 } & \text { Financial Sector } \\ \text { FAD } & \text { Staff } & \text { January 2006 } & \text { Revenue Administration } \\ \text { TGS } & \text { Staff } & \text { June 2001 } & \text { Computerization of treasury } \\ \text { FAD } & \text { Staff } & \text { July 2000 } & \text { Public expenditure management } \\ \text { FAD } & \text { Resident advisor } & 1997 & \text { Tax administration } \\ \text { FAD } & \text { Resident advisor } & \text { July } 1996 & \text { Customs administration } \\ \text { FAD } & \text { Staff } & \text { February } 1995 & \text { Tax reform } \\ \text { FAD } & \text { Staff } & \text { September 1994 } & \text { Public expenditure management } \\ \text { FAD } & \text { Staff } & \text { February 1992 } & \text { Tax reform } \\ \text { FAD } & \text { Staff } & \text { November 1991 } & \text { Budgetary reform }\end{array}$

XI. Resident Representative

In September 2005, Mr. Koffi Yao became resident representative for Benin and Togo. 


\section{II-RELATIONS WITH THE WORLD BANK}

(Updated May 7, 2007)

1. Over the last decade, Togo has been trapped in a vicious cycle of sociopolitical impasse, economic decline, rising poverty, and donor disengagement. Togo has been in nonaccrual status with the International Development Association (IDA) since May 2002, with arrears of US\$106.6 million as of March 2007. During the current non-accrual period, the Bank has continued to conduct analytical and advisory activities (AAA) on key aspects of socioeconomic development. Together with other partners, the Bank also supported the government's efforts to prepare its I-PRSP and development strategies in such sectors as health, education, agriculture and rural development, and HIV/AIDS.

2. The World Bank Executive Board discussed on December 14, 2004, a Country Reengagement Note (CRN) for Togo. It provides a joint strategy for Bank and UNDP reengagement and a framework for strengthening donor assistance that could lead to a clearance of Togo's arrears to IDA and other major creditors and a full resumption of Bank operations in the country.

3. In July 2005, the Bank approved a US\$2.8 million grant under the Low Income Country Under Stress (LICUS) Initiative for a community-driven Emergency Program for Poverty Reduction (EPPR), which aims at helping to halt extreme poverty and the deterioration of social indicators. As of September 2006, approximately \$1 million has been disbursed and financed the completion of some 30 projects (primary schools, health posts, small community infrastructures and community training); the training of some 750 people on community approaches to development and project management; and the establishment of a Bureau de Liaison National, to ensure donor coordination and liaison with Government authorities. Following positive results of an internal evaluation including independent consultants in October 2006, the last phase of the EPPR is in negotiation.

4. On the analytical side, the Bank conducted a Public Expenditure Management and Financial Review (PEMFAR) and a Financial Sector Review (FSR) in the last quarter of 2005. The Bank is working closely with the IMF on a Financial Sector Assessment, an Urban Sector Stocktaking Study, and an Agricultural Development assessment. In addition, the Bank is supporting the government as it strengthens its poverty diagnosis, information systems, and statistical capacities. A Core Welfare Indicator Questionnaire survey was carried out in 2006 to provide for up-to-date and more reliable statistics. A development policy needs review is planned during the current fiscal year.

Contact person: Mr. Eric Nelson, phone (202) 4736699 


\section{III-STATISTICAL ISSUES}

1. Weaknesses in the quality and timeliness of data hamper the effectiveness of surveillance. National accounts and balance of payments statistics are compiled based on very limited information, with only few surveys and scarce data on primary agriculture and private sector services. Moreover, government finance statistics are derived from a weak accounting system, and monetary data are reported by the BCEAO with a two-month lag.

2. Togo participates in the General Data Dissemination System (GDDS) since November 2001. Metadata on the national statistical system, including plans for improvement posted to the Fund's Dissemination Standard Bulletin Board in January 2004, have not been updated since then. Authorities do not report any fiscal data for publication in the International Financial Statistics (IFS) or the Government Financial Statistics (GFS) Yearbook.

\section{National accounts and consumer price index (CPI)}

3. Activity in the informal and service sectors is underestimated, due to the lack of reliable data sources. A full set of national accounts are currently compiled by extrapolating the results of the last comprehensive exercise in 1993. Annual GDP data are compiled with a six-month delay. The CPI uses 1996 weights and its geographical coverage is limited to the city of Lomé.

\section{Balance of Payments}

4. Balance of payments data are compiled based on banks reports, a survey on enterprises, and data from customs. Informal trade, trade in services, and remittances are underestimated. Statistics are compiled with a six-month delay and are revised twice a year.

\section{Government accounts and public debt data}

5. Government finance statistics are derived from a weak accounting system. The monthly TOFE (Table of Central Government Financial Operations) is based on a mixture of administrative and accounting data and is sent to AFR with a two-month lag. Current budget nomenclature does not permit the economic and functional classification of expenditure. There are inconsistencies in domestic arrears records held by different units of the Ministry of Finance and the stock of domestic debt is in the process of being audited. Comprehensive external debt data and projections on a loan by loan basis are compiled regularly.

\section{Monetary statistics}

Monthly data for Togo, as well as other member of the West African Monetary Union (WAMU) are regularly provided to and disseminated by the Central Bank of the West African Monetary Union (BCEAO) and its national agencies. However, data are disseminated with a two-month lag, and sometimes later. Data on interest rates applied by 
domestic banks on their lending and borrowing operations are not compiled. In August 2006, as part of the authorities' efforts to implement the methodology in the Monetary and Financial Statistics Manual, the BCEAO reported to STA monetary data for June 2006 for all member countries using Standardized Report Forms (1SR-central bank, 2SR-other depository corporations, and 5SR-monetary aggregates). These data were reviewed in STA and comments were provided to the authorities. 
Togo: Table of Common Indicators Required for Surveillance (As of May 3, 2007)

\begin{tabular}{|c|c|c|c|c|c|}
\hline Economic Variable & $\begin{array}{l}\text { Date of latest } \\
\text { observation }\end{array}$ & $\begin{array}{l}\text { Date } \\
\text { received }\end{array}$ & $\begin{array}{l}\text { Frequency } \\
\text { of Data }\end{array}$ & $\begin{array}{l}\text { Frequency of } \\
\text { Reporting }^{2}\end{array}$ & $\begin{array}{l}\text { Frequency of } \\
\text { publication }^{6}\end{array}$ \\
\hline Exchange Rates & $\begin{array}{l}\text { March } \\
2007\end{array}$ & $\begin{array}{l}\text { April } \\
2007\end{array}$ & M & Q & $\begin{array}{l}\text { Not } \\
\text { published }\end{array}$ \\
\hline $\begin{array}{l}\text { International Reserve Assets and } \\
\text { Reserve Liabilities of the Monetary } \\
\text { Authorities }\end{array}$ & $\begin{array}{l}\text { December } \\
2006\end{array}$ & $\begin{array}{l}\text { March } \\
2007\end{array}$ & M & Q & $\begin{array}{l}\text { Not } \\
\text { published }\end{array}$ \\
\hline Reserve/Base Money & $\begin{array}{l}\text { February } \\
2007\end{array}$ & $\begin{array}{l}\text { May } \\
2007\end{array}$ & M & Q & $\begin{array}{l}\text { Not } \\
\text { published }\end{array}$ \\
\hline Broad Money & $\begin{array}{l}\text { February } \\
2007\end{array}$ & $\begin{array}{l}\text { May } \\
2007\end{array}$ & M & Q & $\begin{array}{l}\text { Not } \\
\text { published }\end{array}$ \\
\hline Central Bank Balance Sheet & $\begin{array}{l}\text { February } \\
2007\end{array}$ & $\begin{array}{l}\text { May } \\
2007\end{array}$ & M & Q & $\begin{array}{l}\text { Not } \\
\text { published }\end{array}$ \\
\hline $\begin{array}{l}\text { Consolidated Balance Sheet of the } \\
\text { Banking System }\end{array}$ & $\begin{array}{l}\text { February } \\
2007\end{array}$ & $\begin{array}{l}\text { May } \\
2007\end{array}$ & M & SA & $\begin{array}{l}\text { Not } \\
\text { published }\end{array}$ \\
\hline Interest Rates ${ }^{2}$ & $\begin{array}{l}\text { January } \\
2007\end{array}$ & $\begin{array}{l}\text { March } \\
2007\end{array}$ & M & Q & $\begin{array}{l}\text { Not } \\
\text { published }\end{array}$ \\
\hline Consumer Price Index & $\begin{array}{l}\text { January } \\
2007\end{array}$ & $\begin{array}{l}\text { April } \\
2007\end{array}$ & M & SA & $\begin{array}{l}\text { Not } \\
\text { published }\end{array}$ \\
\hline $\begin{array}{l}\text { Revenue, Expenditure, Balance and } \\
\text { Composition of Financing - General } \\
\text { Government } 1\end{array}$ & $\begin{array}{l}\text { February } \\
2007\end{array}$ & $\begin{array}{l}\text { May } \\
2007\end{array}$ & M & M & $\begin{array}{l}\text { Not } \\
\text { published }\end{array}$ \\
\hline $\begin{array}{l}\text { Revenue, Expenditure, Balance and } \\
\text { Composition of Financing- Central } \\
\text { Government }\end{array}$ & $\begin{array}{l}\text { February } \\
2007\end{array}$ & $\begin{array}{l}\text { May } \\
2007\end{array}$ & M & M & $\begin{array}{l}\text { Not } \\
\text { published }\end{array}$ \\
\hline $\begin{array}{l}\text { Stocks of Central Government and } \\
\text { Central Government-Guaranteed } \\
\text { Debt } 5\end{array}$ & $\begin{array}{l}\text { February } \\
2007\end{array}$ & $\begin{array}{l}\text { May } \\
2007\end{array}$ & M & M & $\begin{array}{l}\text { Not } \\
\text { published }\end{array}$ \\
\hline External Current Account Balance & 2006 & $\begin{array}{l}\text { Mission } \\
2007\end{array}$ & $A$ & OM & $\begin{array}{l}\text { Not } \\
\text { published }\end{array}$ \\
\hline $\begin{array}{l}\text { Exports and Imports of Goods and } \\
\text { Services }\end{array}$ & $\begin{array}{c}\text { Dec } \\
2006\end{array}$ & $\begin{array}{l}\text { Mission } \\
2007\end{array}$ & M & OM & $\begin{array}{l}\text { Not } \\
\text { published }\end{array}$ \\
\hline GDP/GNP & 2006 & $\begin{array}{l}\text { Mission } \\
2007\end{array}$ & A & OM & $\begin{array}{l}\text { Not } \\
\text { published }\end{array}$ \\
\hline Gross External Debt & December 2006 & $\begin{array}{l}\text { Mission } \\
2007\end{array}$ & A & OM & $\begin{array}{c}\text { Not } \\
\text { published }\end{array}$ \\
\hline
\end{tabular}




\section{INTERNATIONAL MONETARY FUND \\ Public Information Notice}

EXTERNAL

RELATIONS

DEPARTMENT
Public Information Notice (PIN) No. 07/67

FOR IMMEDIATE RELEASE

June 13, 2007
International Monetary Fund

$70019^{\text {th }}$ Street, NW

Washington, D. C. 20431 USA

\section{IMF Executive Board Concludes 2007 Article IV Consultation with Togo}

On June 8, 2007, the Executive Board of the International Monetary Fund (IMF) concluded the Article IV consultation with Togo. ${ }^{1}$

\section{Background}

1. Togo faces enormous development challenges after 25 years of economic decline. The long-lasting socio-political crisis and withdrawal of donor support have taken a toll on Togo's economy, infrastructure, and institutions. Traditional export sectors have been eroded by adverse terms of trade, real exchange rate appreciation, and the mismanagement of stateowned enterprises. Governance problems and banking sector difficulties have inhibited private investment. Weak fiscal management has led to the rapid accumulation of debt and arrears, and debt is now at unsustainably high levels.

2. Over the past 12 months, Togo has embarked on major political and economic reforms. A central goal is to end the socio-political crisis by holding free and transparent parliamentary elections for the first time in decades, which are also seen as crucial for the resumption of donor support. The authorities have initiated important economic reforms, including steps to strengthen fiscal governance. Economic policies are monitored under a nine-month SMP,

\footnotetext{
${ }^{1}$ Under Article IV of the IMF's Articles of Agreement, the IMF holds bilateral discussions with members, usually every year. A staff team visits the country, collects economic and financial information, and discusses with officials the country's economic developments and policies. On return to headquarters, the staff prepares a report, which forms the basis for discussion by the Executive Board. At the conclusion of the discussion, the Managing Director, as Chairman of the Board, summarizes the views of Executive Directors, and this summary is transmitted to the country's authorities.
} 
which could pave the way for a Poverty Reduction and Growth Facility (PRGF) arrangement and, eventually, debt relief under the Heavily Indebted Poor Countries (HIPC) Initiative and the Multilateral Debt Relief Initiative (MDRI).

3. A modest economic recovery is underway following the slump in 2005. Real GDP grew an estimated 2 percent in 2006, as the improved political climate and dynamism in traderelated services offset the drag on growth caused by the crisis in the cotton sector and daily electricity outages. The current account deficit rose modestly, reflecting the impact of higher oil prices and lower cotton exports. Appreciation of the euro (and thus the CFA franc) against the U.S. dollar and adverse terms of trade have weakened Togo's external competitiveness in recent years. Despite large inflows of liquidity, inflation has been subdued. Broad money grew 22 percent in 2006, as the improved political climate led to a surge in remittances and traderelated capital inflows. While these inflows boosted the banking system's net foreign assets, they did not translate into higher domestic credit. They also did not have a discernible impact on domestic prices. Inflation fell to $2 \frac{1}{4}$ percent in the 12 months to February 2007, as food prices moderated due to improved agricultural supply conditions in neighboring countries.

4. Fiscal policy improved markedly in the second half of 2006. Revenue performance was strong, reflecting recent reforms in administration, tax arrears recovery, and an exceptional profit transfer from the Banque Centrale des Etats de l'Afrique de l'Ouest (BCEAO). The government tightened expenditure control in the second half of 2006 by curtailing offbudget operations. The proceeds from the February 2006 regional bond issue were mostly used to improve public infrastructure and reduce arrears to civil servants and cotton farmers. The domestic primary deficit for 2006 was contained at 1 percent of GDP, and domestic arrears were reduced for the first time in years. External arrears continued to accumulate, reflecting Togo's unsustainably high public debt (about 103 percent of GDP). The 2007 budget aims to anchor macroeconomic stability in an election year by reducing the primary fiscal deficit to $1 / 2$ percent of GDP. The adjustment would come from a sharp reduction in discretionary spending, supported by reforms to minimize the use of exceptional spending procedures. Allocations for health, education, and public infrastructure would remain broadly unchanged.

5. The authorities have embarked on important structural reforms, in particular steps to strengthen fiscal governance. Revenue administration reforms started in mid-2006 with the replacement of the tax and customs directors and closure of bank accounts used to divert revenues for offbudget operations. This was followed by the establishment of internal and external audit programs in the tax department and steps to introduce advanced software in the customs department. Unlike in previous years, spending commitments and payment authorizations under the 2006 budget were closed before December 31, which will help control spending in 2007. A recent audit has validated domestic government debt and arrears of about 21 percent of GDP at end-2005. Audits of the state-owned cotton company the Société Cotonnière du Togo (SOTOCO) are underway, and the government has continued to repay SOTOCO's arrears to farmers. 
6. Despite repeated liquidity injections, several large banks remain fragile and pose a risk to macroeconomic stability. Togolese banks have the highest nonperforming loan (NPL) ratio in the West African Economic and Monetary Union (WAEMU) area, reflecting primarily past lending to loss-making enterprises in the cotton and phosphate sectors. Although the government took over some of the NPLs, several banks have remained severely undercapitalized and one has experienced liquidity problems. The authorities have recently strengthened monitoring of bank liquidity and prepared a strategy to strengthen and restructure the ailing banks, in collaboration with the WAMU Banking Commission and IMF technical assistance.

\section{Executive Board Assessment}

Executive Directors welcomed the recent political and economic reforms in Togo, which mark an important break from the past. Directors noted that the formation of a national unity government and progress toward organizing free parliamentary elections have helped restore economic confidence and supported a nascent economic recovery.

Directors welcomed Togo's good performance under the SMP. They commended the progress made in restoring fiscal discipline and strengthening governance, in particular the reforms to strengthen tax and customs administration and improve expenditure control. Directors also noted the recent audits of domestic debt and of the state-owned cotton company. They encouraged the authorities to complete the remaining structural benchmarks under the SMP and to minimize delays.

Directors cautioned, however, that downside risks to the economic outlook remain substantial, including from possible disruptions in the election process, financial sector weaknesses that could also have adverse spillovers to the regional level, and the deepening problems with energy supply.

Directors stressed the importance of containing fiscal pressures in the run-up to the elections. They noted that the problems of the energy, cotton, and the banking sectors might create additional pressures. To mitigate the risks of expenditure overruns or possible shortfalls in donor support, Directors encouraged the authorities to strengthen spending controls, improve the monitoring of budget execution, and backload nonpriority expenditures to the extent possible.

Directors stressed the need to make progress toward fiscal and debt sustainability. Continued reforms to strengthen fiscal governance will be critical for increasing revenue collection and reallocating spending toward health, education, and infrastructure. A gradual primary fiscal adjustment combined with comprehensive debt relief under the HIPC Initiative and MDRI could help bring debt to sustainable levels and prevent the accumulation of new arrears. Directors 
noted that progress toward the MDGs would require a substantial increase in external assistance from the current low level. Improved public expenditure management was seen as an important prerequisite for securing additional aid flows.

Directors considered that Togo's membership in the WAEMU currency union provides an important anchor of stability. They expressed concern, however, about Togo's loss in external competitiveness over the past two decades, largely caused by weaknesses in governance, deteriorating infrastructure, terms of trade shocks, and-more recently—real exchange rate appreciation. Nevertheless, given Togo's comparatively low wages, Directors saw little evidence of a significant exchange rate overvaluation. At the same time, they stressed the need to improve external competitiveness in order to support higher economic growth and prevent a widening current account deficit. The policy focus should be on raising productivity growth, which will require improving the investment climate through structural reforms, infrastructure investment, and improved fiscal governance.

Directors saw Togo's overarching medium-term challenge as reviving and sustaining economic growth, following a quarter century of decline. They noted that ending the long-lasting political crisis and reengaging with donors will be critical for reviving growth. Reforms of public enterprises in the cotton and phosphate sectors are additional challenges, alongside policies to diversify and raise productivity in agriculture. Directors encouraged the authorities to work with regional partners and donors to alleviate energy shortages, which are increasingly hampering economic activity. They also highlighted the importance of developing the financial sector, including by restructuring ailing banks, and improving the business environment, including through measures to improve governance.

Directors stressed the need to strengthen and restructure several undercapitalized commercial banks, whose financial problems-including the still high level of nonperforming loans-pose a significant risk to stability and constrain the development of the private sector. They were therefore encouraged by the authorities' commitment to implement the recommendations of the WAMU Banking Commission and of IMF technical assistance. Directors also encouraged the authorities to monitor closely the current surge in money growth and be prepared to take corrective policy action in case of emerging inflationary pressures or imprudent lending practices.

Directors noted that successful performance under the SMP could pave the way for consideration of a PRGF arrangement later this year, based on an agreed medium-term economic program consistent with the finalized Interim Poverty Reduction Strategy Paper (I-PRSP). They stressed that this would require understandings with official creditors, including the World Bank, on a mechanism to clear Togo's large external arrears. 
Directors noted that the long-lasting political crisis and withdrawal of donor support had weakened Togo's institutional capacity and highlighted the importance of enhanced technical assistance, including in the fiscal area and in economic statistics.

Public Information Notices (PINs) form part of the IMF's efforts to promote transparency of the IMF's views and analysis of economic developments and policies. With the consent of the country

(or countries) concerned, PINs are issued after Executive Board discussions of Article IV consultations with member countries, of its surveillance of developments at the regional level, of post-program monitoring, and of ex post assessments of member countries with longer-term program engagements. PINs are also issued after Executive Board discussions of general policy matters, unless otherwise decided by the Executive Board in a particular case. 
Togo: Selected Economic Indicators

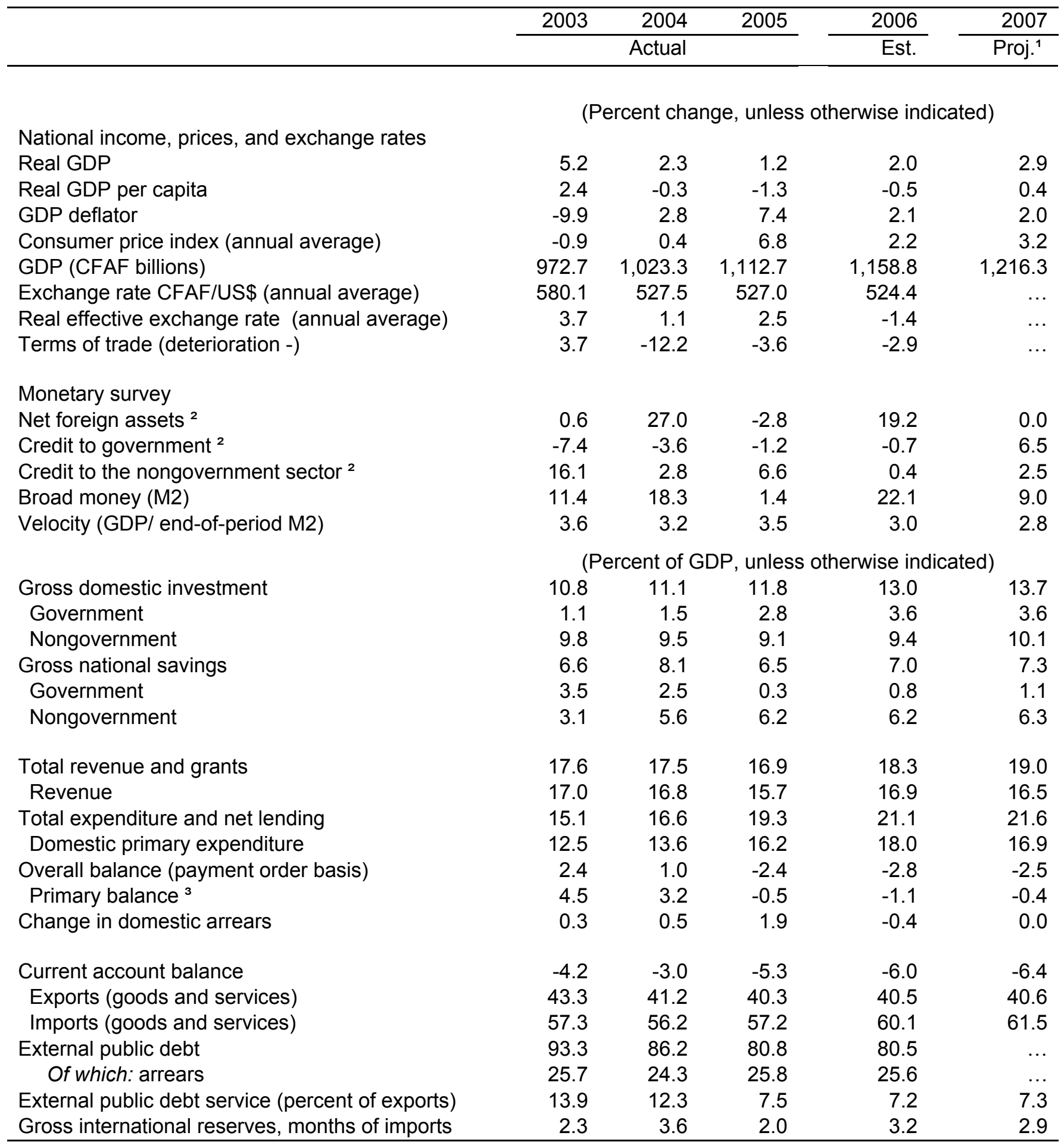

Sources: Togolese authorities; and Fund staff estimates and projections.

${ }^{1}$ Projection reflects SMP objectives and the 2007 budget. Assumes external arrears rescheduling and relief.

2 Percent of broad money at the beginning of the period.

${ }^{3}$ Revenue minus expenditure, excluding grants, interest, and foreign-financed expenditure. 


\section{Statement by Laurean W. Rutayisire, Executive Director for Togo June 8, 2007}

At the outset, I would like to express the appreciation of my Togolese authorities to the Executive Board, Management and Staff for their valuable support and advice since they embarked on implementing the current Staff Monitored Program. I also would like on behalf of my authorities to thank staff for the fruitful dialogue held during the recent discussions under the 2007 Article IV consultation and review of the SMP, as well as for the helpful set of papers which well documents Togos̉ economic developments and performances.

Since October 2006, my authorities have within the framework of SMP embarked on macroeconomic and structural reforms designed to restore macroeconomic stability, and achieve sustained growth in order to make inroads in poverty reduction and achieving the MDGs. Despite the unfavorable economic environment due in particular to the increase in oil prices and difficult situation in the energy and cotton sectors, my Togolese authorities have maintained determined implementation of the SMP and as evidenced in the staff report have met all performance criteria.

Following the slump recorded in 2005, a 2 percent real GDP was achieved in 2006. Inflation was also significantly reduced as the consumer price index dropped from 6.8 percent in 2005 to 2.2 percent in 2006 .

Fiscal performance has been strong. Revenues exceeded the end-2006 target, on account of reforms in tax and customs administration as well as the strong recovery of tax arrears, and expenditure control was tightened by curtailing off budget operations. Consequently, the domestic primary deficit for 2006 was contained at 1 percent of GDP, below the program target of 1.75 percent and domestic arrears were reduced for the first time in years. All structural benchmarks under the SMP through February were met. To help control spending in 2007, all spending commitments and payment authorizations under the 2006 budget were closed before December 31, 2006. In February 2007, the authorities adopted a decree establishing internal and external audit programs in the tax department. The principles of an arrears clearance strategy based on a draft audit were discussed with the IMF mission. The preliminary financial audit report on SOTOCO has been also issued. The authorities are implementing further reforms, including tax audits and customs'computer ization, in order to enhance revenue collection.

With regard to the external sector, the gross international reserves increased to 3.2 months of imports from 2.0 months in 2005. However, the adverse impact of higher oil prices and lower cotton exports led to the widening of the current account deficit to 6 percent of GDP.

On the political front, my authorities have also made important achievements in building governance institutions and democratization. In August 2006 a global political agreement 
involving all major political parties was signed followed by the formation of a national unity government in September 2006. Free and fair legislative elections will be organized before the end of 2007 by an independent national electoral commission established in October 2006.

In spite of these performances, the authorities still face daunting challenges in order to revive economic growth, reduce external imbalances and eradicate poverty after more than two decades of decline. In order to overcome these challenges and based on the policy implementation performances made under the SMP as well as their strong commitment to pursue sound policies and reforms, my Togolese authorities are requesting a PRGF arrangement in order to enable them to mobilize broader donor aid support and debt relief.

\section{Program for 2007}

In 2007, real GDP growth is projected at 3 percent, driven mainly by higher public investment, increase in cotton production and continued strong growth in services related to regional trade. A higher and sustainable economic growth is needed in order to make significant inroads in poverty reduction. To this end, the authorities are developing a comprehensive reform strategy based on the Interim PRSP. This reform strategy covers (i) political and economic governance, including political and legal reforms, and steps to strengthen public finances and budget execution; (ii) structural reforms with actions to improve business environment, restructure state-owned enterprises, raise agricultural productivity, build infrastructure and develop the financial sector and (iii) social reforms including wider access to education, health, and safe water.

\section{Fiscal Policy and Reform}

My Togolese authorities remain strongly committed to fiscal discipline and sound budgetary processes. To support the increase in revenue collection, they are planning a broad set of administrative reforms designed to strengthen tax administration and reduce fiscal risks. This reform includes computerization, improved audit procedures and simplified procedures for taxpayers. To restore confidence of local suppliers, the authorities intend to avoid new arrears and develop a repayment strategy for past arrears following the recent audit. They also envisage a gradual domestic fiscal adjustment based on a gradual increase in revenues and a reallocation of spending towards priority area, namely public infrastructure, education and health. In view of the heavy public debt burden, the authorities call on higher external assistance and comprehensive debt relief, in order to meet spending needs in the context of fiscal and debt sustainability. The lack of external support for more than a decade has significantly weakened the countrys institutional and human cap acity and eroded its physical infrastructure, whose rehabilitation requires substantial financial support in addition to the domestic fiscal adjustment effort. 


\section{Monetary Policy and Banking Sector Reform}

The current exchange rate regime has served the economy well, with significant benefits in terms of low inflation and access to regional markets. The Togolese banking sector remains fragile. The authorities are aware that this situation could jeopardize the macroeconomic stability. In their efforts to strengthen the sector, the authorities have significantly reduced the NPL ratio from 42 to 28 percent. The regional banking commission has made wide ranging recommendations to step up the authorities'efforts to address the problems experienced by the Togolese banks. Good progress has been made in implementing many of Commission'measures, and the authorities are committed to press ahead with further strengthening the banks'govern ance and financial position.

\section{Structural Reforms and Competitiveness}

The authorities aim to make further progress in the structural reforms, with a view to boost higher growth and revive the external competitiveness of the economy. In this regard, the authorities intend to improve the broader business environment, including by strengthening governance and simplifying regulations to attract foreign direct investment. They will also speed up reforms of state-owned enterprises with the clearance of arrears to cotton farmers and audit of SOCOTO as well as seeking a strong strategic investor for the phosphate sector. In their efforts to address problems in the energy sector, the authorities plan to work with regional partners and private investors to alleviate the main constraints. To enhance financial intermediation and lower interest rates, the authorities intend to restructure and privatize the state-owned banks, develop microfinance to enhance access to financial services for the SMEs and households and increase the liquidity and depth of primary and secondary securities markets. Further steps will also be undertaken to improve the legal environment and the ability of banks to recover credit collaterals.

Regarding the urgent need to upgrade the countrys sta tistical capacity, my Togolese authorities call on the Fund for a technical assistance in the areas of the balance of payments, and national accounts as well as monetary and fiscal data.

\section{Conclusion}

My authorities fully share the staffs analysis on debt sustainability which shows that Togo is in debt distress and highlights the need for increased external assistance coupled with benefiting from HIPC Initiative and MDRI.

My Togolese authorities remain determined to pursue steadfastly the implementation of good policies. Once again they would appreciate Directors support of their request for a PRGF arrangement, in order to back their efforts towards poverty alleviation and achieving the MDGs. 